\title{
ADITIVOS MINERAIS PARA VIABILIZAÇÃO DE ATERROS EXCLUSIVOS DE LODOS DE ESTAÇÕES DE TRATAMENTO DE ESGOTOS (ETES)
}

\author{
HILTON FELÍCIO DOS SANTOS
}

Tese de Doutorado apresentada ao Departamento de Saúde Ambiental da Faculdade de Saúde Pública da Universidade de São Paulo para obtenção do Grau de Doutor

Área de Concentração:

Saúde Ambiental

ORIENTADOR:

PROF. DR. PEDRO CAETANO SANCHES MANCUSO

São Paulo 


\section{ADITIVOS MINERAIS PARA VIABILIZAÇÃO DE ATERROS EXCLUSIVOS DE LODOS DE ESTAÇÕES DE TRATAMENTO DE ESGOTOS (ETES)}

HILTON FELÍCIO DOS SANTOS

Tese de Doutorado apresentada ao Departamento de Saúde Ambiental da Faculdade de Saúde Pública da Universidade de São Paulo para obtenção do Grau de Doutor

Área de Concentração:

Saúde Ambiental

ORIENTADOR:

PROF. DR. PEDRO CAETANO SANCHES MANCUSO

São Paulo 


\section{AGRADECIMENTOS}

Meus agradecimentos ao Prof. Dr. Pedro Caetano Sanches Mancuso pela orientação prestada e pelo incentivo permanente na realização deste trabalho acadêmico.

Agradeço à Companhia de Saneamento Básico do Estado de São Paulo pela cessão de dados de seu acervo e em especial à equipe de operação da Estação de Tratamento de Esgotos de Barueri cujo apoio foi fundamental para realização dos estudos de campo. 


\section{ÍNDICE}

\section{RESUMO}

\section{SUMMARY}

LISTA DE TABELAS

\section{LISTA DE FIGURAS}

1. INTRODUÇÃO 1

1.1 Antecedentes 1

1.2 Porque aditivos minerais nos aterros exclusivos 4

1.3 Solos de empréstimo como aditivo 5

$\begin{array}{lll}1.4 & \text { A cal como aditivo } & 7\end{array}$

1.5 O Absorsol e outros aditivos minerais 9

$\begin{array}{ll}\text { 2. OBJETIVOS } & 17\end{array}$

3. REVISÃO DA LITERATURA 18

$\begin{array}{lll}3.1 & \text { Disposição de lodos em aterros } & 18\end{array}$

3.2 Tipos de aterro 23

3.2.1 Aterros exclusivos de lodo 23

3.2.2 Aterros mistos de lodo 25

3.3 Aterro exclusivo de lodo projetado para a RMSP 29 
4. MATERIAIS E MÉTODOS

4.1.1 Filtros-prensa da estação de Barueri

4.1.2 Cal virgem para as pistas experimentais

4.1.3 Equipamento de mistura de aditivos na torta de lodo para construção da pista

4.1.4 Ensaio do Índice Suporte Califórnia (ISC)

4.1.5 Uso do ISC na avaliação das pistas experimentais

4.1.6 Ensaios de compressão simples e outros ensaios

4.2.1 Coleta de amostras para tortas précondicionadas com cal

4.2.2 Formação das pilhas para execução das pistas experimentais e análises para uso agricola do biossólido (précondicionamento: cal)

4.2.3 Conceito das pistas com tortas das pilhas E e F. Planejamento das análises de caracterização do lodo das pistas após recebimento dos aditivos (précondicionamento: cal) 
4.2.4 Construção das pistas experimentais com as tortas de filtro-prensa précondicionadas com cal e cloreto férrico

4.2.5 Estudos geotécnicos nas pistas feitas a partir das tortas de lodo pré-condicionadas com cal e cloreto férrico

4.2.6 Coleta de amostras para tortas précondicionadas com polimero

4.2.7 Ensaios de laboratório a partir das tortas de lodo précondicionadas com polimero

A - Caracterização química do sílico-aluminato de cálcio e magnésio, Absorsol

B - Ilustração esquemática das amostras de laboratório para as situações das tortas preparadas com: 1 - cal e cloreto férrico e 2 - polímero 


\section{LISTA DE TABELAS}

Tabela 1: Características de condicionadores minerais naturais

Tabela 2: Produção comparativa de lodo na ETE Barueri conforme o

condicionamento quimica antes da filtragem

34

Tabela 3: Experiências anteriores de mistura de tortas de lodo com materiais diversos e rendimentos obtidos

Tabela 4: Datas de coleta e concentração de sólidos das tortas (Amostra R $=\mathrm{A}+\mathrm{B}+\mathrm{C}+\mathrm{D})$

Tabela 5: Análises fisico-químicas na amostra R (NBR 10.004)

Tabela 6: Análises microbiológicas na amostra $\mathrm{R}$

Tabela 7: Datas de coleta e concentração de sólidos das tortas

(Amostra $\mathrm{E}=$ antes do acréscimo de Absorsol/cal adicional)

Tabela 8: Análises fisico-quimicas na amostra E (NBR 10.004)

Tabela 9: Análises microbiológicas na amostra $\mathrm{E}$

Tabela 10: Datas de coleta e concentração de sólidos das tortas (Amostra $\mathrm{F}=$ antes do acréscimo adicional de cal virgem) 
Tabela 13: Datas das retiradas de amostras das pistas para caracterização físico-química e microbiológica do material da plataforma

Tabela 14: Análises físico-quimicas na amostra da pista Cal-01

Tabela 15: Análises microbiológicas na amostra da pista de Cal -01

Tabela 16: Análises físico-químicas na amostra da pista Cal-02

Tabela 17: Análises microbiológicas na amostra da pista de Cal -02

Tabela 18: Análises fisico-químicas na amostra da pista Cal-03

Tabela 19: Análises microbiológicas na amostra da pista de Cal -03

Tabela 20: Análises fisico-quimicas na amostra da pista ABS-01

80

Tabela 21: Análises microbiológicas na amostra da pista de ABS -01

Tabela 22: Análises físico-quimicas na amostra da pista $\mathrm{ABS}+\mathrm{Cal}-01$

Tabela 23: Análises microbiológicas na amostra da pista de ABS + Cal -01

Tabela 24: Análises fisico-químicas na amostra da pista ABS + Cal-02 
Tabela 26: Temperaturas das amostras de lodo decorrentes da adição de cal virgem

Tabela 27 Média dos resultados para duas amostras dos ensaios de compressão simples e ISC para tortas précondicionadas com polímeros

Tabela 28: Comparação da qualidade fisico-quimica das amostras de torta précondicionada com cal e cloreto férrico, antes e depois da mistura com aditivos adicionais

Tabela 29: Qualidade microbiológica das amostras de torta précondicionada com cal e cloreto férrico, antes e depois da mistura com aditivos adicionais

Tabela 30: Confirmação dos resultados da qualidade microbiológica das amostras de torta précondicionada com cal e cloreto férrico, antes e depois da mistura com aditivos adicionais 


\section{LISTA DE FIGURAS}

Figura 1: Aterro exclusivo de várias camadas superpostas para lodos de ETES

Figura 2: Distribuição da água intersticial no lodo

Figura 3 Secção transversal típica do aterro exclusivo multinivel Classe 1 da Sabesp

Figura 4 Descarga do lodo de um dos filtros prensa da ETE Barueri

Figura 5 Caminhões de cal virgem ao fundo e pista protegida com lonas plásticas em primeiro plano

Figura 6 Descarga do 'big-bag' de cal do caminhão

Figura 7 Big-bags de cal virgem, apoiados em pallets, e cobertos por lona Plástica

Figura 8 Equipamento para mistura de aditivos na torta de lodo

Figura 9 Detalhe do alimentador de rosca

Figura 10 Descarga da torta do filtro na plataforma do misturador de aditivos, vendo-se o saco de Absorsol à direita da foto

Figura 11: Descarga das tortas de lodo e coleta das amostras para as pilhas A, B, C e D

Figura 12: Recipientes para amostras A,B, C, D e amostra C fora do seu 
recipiente

Figura 13: Quarteamento das amostras e eliminação de duas frações,

Conforme a NBR 10007 - Amostragem de Residuos

Figura 14 Pá mecânica de pneus descarregando a torta no terreno da pista 58

Figura 15 (a) Pilhas A, B, C, D formadas e protegidas com plástico contra chuva. (b) Abaixo, a pilha B foi descoberta e removida parcialmente

Figura 16 Descarga da torta mais Absorsol do misturador especial

Figura 17 Aspecto da mistura da torta do filtro prensa mais 7\% de Absorsol 87

Figura 18: Descarga da torta misturada com $17,5 \%$ de cal no misturador.

Figura 19: Lodo com 17,5\% de cal virgem notando-se desprendimento de amônia onde indicado, após cerca de 15 minutos da mistura

Figura 20: Mistura com 17,5\% de cal. Notar, pela diferença de coloração, a rápida secagem (cerca de 1 hora)

Figura 21: Espalhamento do lodo no inicio de construção das pistas

Figura 22: Aspecto das pistas construidas com as pilhas $\mathrm{E}$ e $\mathrm{F}$, respectivamente à esquerda e a direita da foto.

Figura 23: Pista experimental com torta de filtro prensa e $17,5 \%$ de cal virgem notando-se desprendimento de amônia após passagem do trator de 
esteira D-4.

Figura 24: Retirada de amostra para ensaio de compressão simples antes do espalhamento da pista lodo $+17,5 \%$ de cal (temperatura $\pm 800 \mathrm{C}$ ) 92

Figura 25: Cilindros para envio ao laboratório de solos

Figura 26: Variação da resistência à compressão simples de 0 a 40 dias

Figura 27: Coleta de amostra da pista com 17,5\% de cal, após espalhamento da torta pelo $\mathrm{D}-4$, para o ensaio de ISC

Figura 28: Coleta de amostra para o ensaio de ISC

Figura 29: Variação do ISC de 0 a 40 dias

Figura 30: Variação da massa seca da torta nas pistas, de 0 a 40 dias

Figura 31: Pista com 7\% de Absorsol mostrando baixa resistência ao tráfego da esteira de um trator $\mathrm{D}-4$.

Figura 32: Tentativa de compactação da pista com 7\% de Absorsol

Figura 33: Pista com 17,5\% de cal virgem após espalhamento e compactação 99

Figura 34: Compactação da pista com $8 \%$ de cal e 4\% de Absorsol 100

Figura 35: Pista de tortas de lodo com $8 \%$ de cal e 4\% de Absorsol 30 dias após a compactação 
Figura 36: Torta preparada com polimero misturada com cal no laboratório 104

Figura 37: Da esquerda para a direita corpos de prova, rompidos, com 5\%, $10 \%$ e $20 \%$ de cal

Figura 38: Colocação da amostra em cilindro para moldar o corpo de prova 106

Figura 39: Rompimento de corpo de corpo de prova com 5\% de cal, sendo mostrado o anel dinamométrico utilizado para determinar os esforços aplicados.

Figura 40: Rompimento de corpo de prova com $20 \%$ de cal 108

Figura 41: Ensaio de compressão simples para dosagens diversas de cal nas tortas précondicionadas com polímeros

Figura 42: ISC: Colocação da amostra homogeneizada no molde cilindrico

Figura 43: ISC: Compactação da amostra com peso e altura de queda conforme especificação do ensaio.

Figura 44: ISC: Preparação da amostra para a pesagem

Figura 45: Pesagem do molde cilíndrico contendo a amostra

Figura 46: Amostra sendo prensada com destaque para o pistão de penetração

Figura 47: Ensaio de determinação do ISC para dosagens diversas de cal nas tortas précondicionadas com polimeros 


\section{RESUMO}

Durante os trabalhos do plano diretor de lodos para as cinco principais estações de tratamento de esgotos sanitários (ETE's) da área metropolitana de São Paulo recomendou-se a construção de pistas com tortas de filtro-prensa misturadas com aditivos minerais altemativos. As pistas simulariam a viabilidade construtiva dos aterros exclusivos de lodo em escala real. $O$ projeto deste aterro previa células sobrepostas, recurso de engenharia contra a exigüidade de terrenos adequados próximos das ETES.

Os aterros exclusivos foram vistos, convergentemente, como único volante capaz de absorver a quantidade de lodo não utilizada para a agricultura de grãos, reflorestamentos de Eucaliptus Grandis e outros usos úteis. Os aterros seriam construidos gradativamente, pela própria operação diária de destino do lodo, sendo essencial que fossem capazes de suportar o tráfego dos caminhões de lodo.

Esta tese investiga a capacidade de resistência ao tráfego de pistas experimentais construidas com tortas de filtro-prensa da ETE Barueri e também verifica sua qualidade para possível uso agrícola como condicionador de solos.

Antes da filtragem o lodo recebia cloreto férrico e cal. Posteriormente passou a receber polímeros e cloreto férrico. Foram testadas várias pistas de $30 \times 7 \times 0,5$ metros no pátio da ETE, retirando-se amostras para medição de parâmetros úteis à construção dos aterros e/ou seu preferível uso agricola. Foram assim determinados a umidade do lodo, sua resistência à compressão simples, o Índice Suporte Califórnia e as características químicas e biológicas das tortas pré-condicionadas com cal.

Os ensaios de laboratório de solos com amostras retiradas dessas pistas indicaram a viabilidade construtiva do proposto. A mistura adicional com Absorsol, um silicoaluminato de cálcio e magnésio, também foi verificada, indicando menor consumo de cal para construir a pista, com algum sacrificio na capacidade de suporte ao tráfego.

Não foram construídas pistas depois que o pré-condicionamento mudou para polimeros porque os ensaios de laboratório com estas indicaram sua baixa resistência à compressão, para várias dosagens adicionais de cal.

As tortas pré-condicionadas com cal foram julgadas adequadas para uso agrícola, tanto no aspecto físico-químico quanto no parasitológico e microbiológico. Em 1999 a Sabesp constatou que continuavam adequadas, mesmo sem adição de cal.

A tese recomenda a construção de pistas experimentais no aterro Anhanguera, no primeiro dos três terrenos já escolhidos pela Sabesp, com o objetivo de quantificar, projetar e estimar custos da agregação de cal ao lodo, hoje pré-condicionado com polimeros. Esta agregação será indispensável, como foi demonstrado, visto que sem ela não há possibilidade dos caminhões e/ou maquinário deixarem de afundar enquanto estiverem trafegando sobre o aterro, durante a descarga e compactação do lodo.

Recomenda-se ainda investigar as condições geotécnicas resultantes nestas pistas se o Absorsol for também usado como aditivo, juntamente com a cal, para evitar a produção de fenóis - verificada na pista experimental - e para diminuir o consumo de cal na construção do aterro.

Descritores: Teses Acadêmicas. Disposição de Lodos de ETES. Aterros Exclusivos. 


\section{SUMMARY}

Field experiments regarding monofill prototypes were recommended in the Master Plan for Treatment and Final Disposal of Wastewater Sludges from all five large activated sludge wastewater treatment plants of Sao Paulo Metropolitan Area. The prototypes would simulate the construction feasibility of the future sludge monoffills since their design forecasted superimposed sludge layers of dozen of meters due to the limited availability of suitable areas within reasonable distances from the plants.

There was a general agreement regarding the directive to build monofills because they would be needed for biosolid volumes not used for better and preferred purposes, such as grain crops and Eucalyptus Grandis reforestations, for instance. They should grow slowly, as a daily consequence of the plant operation, and they should have, as a must, the ability to support the traffic load of the sludge cakes hauling vehicles.

This doctorate research investigates both, how well monofill prototypes could resist machinery traffic and how suitable were Barueri plant sludge cakes for land application purposes as biosolids.

A number of $30 \mathrm{~m} \times 7 \mathrm{~m} \times 0.5 \mathrm{~m}$ road stretches using sludge cakes plus mineral amendments were built within Barueri's WWTP yard. The material was limed ferric chloride filter-pressed cakes. At a later date polymers substitute the lime. Prior to be compacted, the cakes were further amended with quick-lime, with good results, and/or with a calcium magnesium silicate (Absorsol), with some lime savings though with less compaction resistance. Dozens of photos are included into the present thesis.

Graphics are also presented in order to show the variability of some geotechnical parameters, such as simple (non-confined) compression, California Bearing Ratio and sludge moisture through time. Physical, chemical, parasitological and microbiological analyses have been carried out both from cakes and from the compacted experimental road fill.

After lime replace polymers prior filtration, no prototypes were built, because laboratory soil essays have shown unacceptable compaction resistance of the further amended cake for a number of additional lime dosages.

Limed cakes were found suitable for agriculture use. Sabesp has recently (1999) verified that they may still suit agricultural purposes, though lime is no longer added.

The thesis recommends that a prototype be built in Sabesp's Anhanguera monofill site to quantify design parameters, mainly the additional lime quantities to today's polymer conditioned cakes. Mineral amendments are essential, as demonstrated, to keep trucks and earthmoving equipment circulating over the fill.

Geotechnical behavior when Absorsol is added should also be verified. Depending upon favorable results, it would avoid phenols releasing when further lime is added - as experimentally verified - and might save lime amendment to soil.

Descriptors: Thesis, Academic. Wastewater Sludge Disposal. Monofill 


\section{INTRODUÇĀO}

\subsection{Antecedentes}

A motivação para os trabalhos desta tese surgiu durante os estudos do plano diretor para tratamento e disposição final dos lodos das cinco grandes estações de tratamento de esgotos sanitários (ETES) da área metropolitana de São Paulo (RMSP). Esses estudos, contratados pela Sabesp a partir de 1992, tinham por objetivo a recuperação ambiental da área metropolitana através de projetos e obras. Foram geridos pela Sabesp-CetesbDAEE e por um Consórcio Gerenciador de empresas privadas, integrantes de um grupo executivo criado pelo governo estadual em 1991 para implantação da primeira fase do empreendimento conhecido como "Projeto Tietê".

No início da década passada, São Paulo possuía apenas duas grandes ETES em operação: Suzano e Barueri. Mesmo antes do começo das atividades do grupo executivo e do referido plano diretor, a Sabesp foi compelida, como condição para liberação da parcela financiada pelo BID, a indicar um destino para os lodos do tratamento já produzido nestas duas instalações mais os que seriam retidos nas três novas ETES (ABC, São Miguel e Parque Novo Mundo) a serem construídas pelo "Projeto Tietê".

Consultores nacionais, assessorados por uma empresa de consultoria francesa, indicaram como solução para o problema a construção de dois aterros exclusivos para lodos, denominados aterros "Leste" e "Oeste". Estes aterros deveriam possuir altura de dezenas de metros e não possuíam antecedente em outros locais do mundo. A razão para a grande altura era a exigüidade de áreas adequadas na RMSP para acomodar as 750 toneladas de lodo diárias, em base seca - quase 2.000 t/dia de tortas de filtro-prensa previstas para o ano 2.015. O consórcio franco-brasileiro recomendou que fossem 
construidas algumas pistas experimentais, ou mini-aterros exclusivos, com as tortas de lodo misturadas com cal, com terra e/ou com outros aditivos, para que se determinassem parâmetros geotécnicos úteis ao projeto pioneiro desses aterros.

Consultores britânicos que assessoravam outra área da Sabesp trouxeram dois especialistas em grandes barragens de terra, especificamente para darem seu parecer. Ambos ratificaram, como condição essencial para o projeto desses aterros de grande altura, o estudo geotécnico em "pistas experimentais".

O plano diretor de lodos, finalmente contratado, centrou suas recomendações na construção de uma central de secagem térmica na ETE São Miguel (recebendo seus lodos e os das ETES de Suzano e Parque Novo Mundo) para uso agricola do granulado praticamente seco e não descartou outros usos úteis, como o das tortas de lodo em agricultura de grãos e reflorestamentos. Entretanto, ratificou com máxima ênfase, ser imprescindivel a disposição em aterros para a (maior) parcela de lodo sem reaproveitamento aceitável como sejam disposição de tortas, granulado seco termicamente e/ou cinzas de incineração, caso esta venha a ser uma opção futura. E por causa da competição pelo uso do solo urbano da metrópole reafirmou a necessidade de se construir aterros de grande altura em camadas superpostas, tal como recomendado por franceses, britânicos e brasileiros no passado.

Em 2.002 a central de secagem térmica de São Miguel iniciou sua operação e as áreas para os aterros foram finalmente adquiridas ao longo da via Anhanguera, pouco depois do aterro municipal para o lixo (aterro Bandeirantes).

A concepção desta obra pioneira pode ser visualizada na figura 1. 


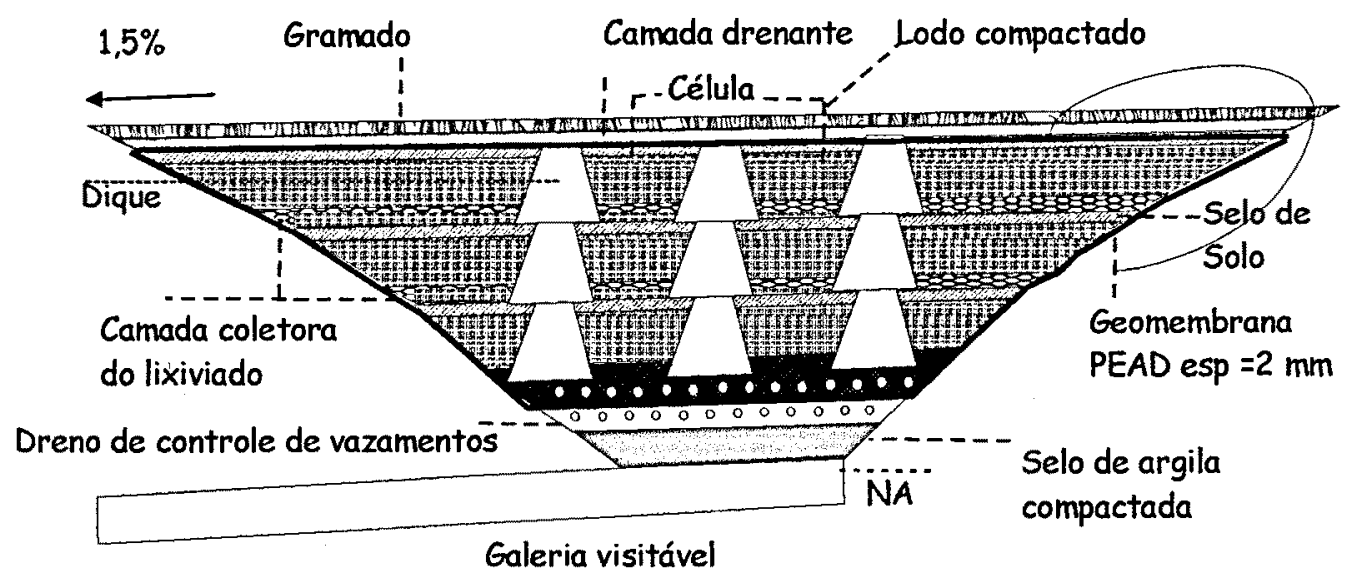

Figura 1 Aterro exclusivo de várias camadas superpostas para lodos de ETES Fonte: Vasconcellos et al, 1995

O plano diretor de lodos para as ETES da RMSP considerou como principais vantagens da destinação aterros exclusivos:

- Apresentam menor prazo de implantação do que outras alternativas consideradas.

- São capazes de absorver grandes quantidades de lodo, independentemente de sua qualidade, porque serão construídos seguindo as especificações prescritas para aterros de resíduos classe I.

- Podem absorver a demanda adicional não consumida pelas soluções de uso útil do lodo, dentre as quais destaca-se o uso agrícola para lodos predominante classe II da NBR 10.004 e biologicamente enquadráveis pela Cetesb, no mínimo, na classe B.

- Podem receber eventuais cinzas de incineração.

- Constituem uma reserva permanente e sempre disponivel para a disposição do lodo que não esteja sendo reciclado. 


\subsection{Porque aditivos minerais nos aterros exclusivos}

Os aterros apenas de lodos não possuem capacidade de suportar o tráfego dos veículos que o transportam até o local e que precisariam trafegar sobre ele durante a descarga. Deve também ser capaz de suportar o tráfego de um trator de esteiras de pequeno porte, como o D-4 da Caterpillar, previsto para compactar e espalhar o lodo durante sua operação diária de descarga no aterro. (Sabesp, 1998)

Experiências na ETE Barueri na década de 90 (Nogueira e Santos, 1995a, 1995b) comprovaram que lodo condicionado com $22 \%$ de cal e $8 \%$ de cloreto férrico para fins de desidratação em filtros-prensa seria incapaz de suportar o tráfego de caminhões e/ou tratores quando colocado numa célula experimental de $30 \times 5 \times 1,5 \mathrm{~m}$ no pátio da ETE, mesmo depois de alguns dias ao sol. $\mathrm{O}$ único tráfego possivel foi $\mathrm{o}$ de um pequeno "Bob-Cat", mas somente depois da colocação de $0,50 \mathrm{~m}$ de terra por cima dos $0,60 \mathrm{~m}$ de lodo.

Por este motivo durante os trabalhos desta tese foram experimentadas misturas adicionais de cal virgem na torta de lodo a $40 \%$ de sólidos, pré-condicionada com cal e cloreto férrico, e também na torta resultante do pré-condicionamento com polímeros $\mathrm{e}$ cloreto férrico. No primeiro caso foram realizados ensaios de laboratório e pistas experimentais; no segundo, apenas ensaios de laboratório.

Além da cal, outros aditivos foram propostos no Plano Diretor, como terra, em grande quantidade e cinzas de uma eventual incineração futura dos lodos. Durante a fase de

\footnotetext{
- Uma mini-pá carregadeira tipo Bob-Cat tem o peso operacional de $2950 \mathrm{~kg}$ (http://www.escad.com.br/paginatec/Pte853.htm)[21.01.03]
} 
campo desta tese foi também testado um silico-aluminato de cálcio e magnésio, comercialmente conhecido como Absorsol, misturado às tortas précondicionadas de ambas formas descritas.

\subsection{Solos de empréstimo como aditivos}

Sieger e col., 1994, estudaram a disposição dos lodos das duas ETE's da cidade de Alexandria, 4 milhões de habitantes, no Egito. Os lodos primários de uma das ETE's eram secos ao tempo, tendo-se em vista que a direção dominante dos ventos e a proximidade do deserto tornavam esta solução aceitável. O da outra ETE chegava a $25 \%$ de sólidos mediante filtros-esteira, um resultado usualmente excepcional para este tipo de equipamento, mas possivel por se tratar de lodo primário. Ambos lodos eram extirpados do lixo (gradeados e desarenados) pelo tratamento preliminar nas ETE's, mas apenas $10 \%$ do total destinava-se à compostagem para uso agrícola. Os $90 \%$ restantes $(180 \mathrm{t} / \mathrm{d}$, base seca), deveriam ser aterrados juntamente com os resíduos do tratamento preliminar

A disposição estudada inicialmente considerou o aterro em valas de seção transversal trapezoidal de $6 \mathrm{~m} \times 11 \mathrm{~m}$ (largura da base $\times$ largura no topo), com $5 \mathrm{~m}$ de profundidade e aproveitando metade da largura do terreno. Durante as sondagens e ensaios geotécnicos verificou-se, entretanto, que o material do subsolo era constituído por uma dolomita extremamente dificil de ser escavada (basicamente uma pedra de cal com alta porcentagem de magnésio). Algumas áreas chegavam a ter $2 \mathrm{~m}$ de dolomita abaixo do solo superficial e eram incapazes de serem terraplenadas com tratores de lâmina de grande porte. A dolomita, a areia argilosa, e os arenitos encontrados, requeriam de 0,5 hora a 1,5 hora por metro de avanço de escavação. $O$ material ainda produzia intenso pó quando removido, o que criava inúmeros problemas no momento e que certamente continuaria a criar ao longo dos próximos 20 anos de exploração do aterro, situação que seria agravada pelos fortes ventos locais. 
Para evitar que o lodo a $25 \%$ de sólidos se transformasse numa geléia quando fosse coberto pela terra, já se previa sua mistura com aditivos, antes que fossem lançados no aterro. Antecipava-se que esta agregação permitiria colocar $1,5 \mathrm{~m}$ de solo de cobertura usando um equipamento de terraplenagem de energia de compactação reduzida.

\section{Entretanto, mesmo utilizando-se cerca de duas a quatro vezes mais terra do que o} volume dos sólidos no lodo, (grifo deste texto) o material ainda seria potencialmente instável nas profundidades planejadas. Previa-se, por este motivo, que uma leira de terra fosse deixada no respaldo da vala para que se evitasse qualquer tráfego futuro sobre ela. Seria possível reutilizar área para um parque mas isto não corresponderia a uma necessidade local por causa da escassez de água para manutenção do verde. Mais grave ainda era o espaço perdido nas valas pela agregação de solo ao lodo.

A solução encontrada foi a da disposição em terreno dedicado, ou DLD, “dedicated land disposal". Favoreciam a escolha desta solução a existência do terreno dolomitico, capaz de estabilizar os lodos a um pH de 9 e combater odores ofensivos. Dificultavam esta diretriz a necessidade de se fazer um aterro separado para a escuma e os gradeados, inaceitáveis em um DLD. Estes residuos foram resolvidos com seis valas de $16 \times 4 \times$ $325 \mathrm{~m}(\mathrm{~b} \times \mathrm{h} \times \mathrm{L})$, revestidas no fundo com geomembrana impermeabilizante, brita $\mathrm{e}$ drenos. Os drenos das valas foram dirigidos para lagoas de evaporação. As valas recebiam cobertura diária de solo e, uma vez concluídas, eram encerradas com geomembrana impermeabilizante, ficando o local com acesso restrito.

Quanto ao lodo, foi feito seu espalhamento sobre o terreno, com uma espessura de $7 \mathrm{~cm}$, seguida da incorporação à uma profundidade de $10 \mathrm{~cm}$, conseguindo-se sua secagem rápida e evitando-se o desprendimento de odores ofensivos. A taxa de aplicação de 1.800 tha impedia o crescimento de qualquer vegetação, mas o solo mostrou-se adequado para enriquecimento da lavoura local depois de um ano de operação, devido ao seu alto teor de húmus. Isto incrementou o uso que o lodo já vinha tendo através da 
compostagem. Um limitador de um maior sucesso desta solução foi a presença da areia do esgoto, trazendo vidro e outras impurezas que atrapalhavam o uso útil.

A experiência de Sieger e colaboradores foi relatada para ilustrar um precedente para o grande volume de solo de empréstimo previsto para o aterro exclusivo de lodos na RMSP. Estima-se em 3,5 milhões $\mathrm{de}^{3}$ a quantidade de solo importado que virá de duas áreas de empréstimo dentro dos limites da propriedade, a 1,3 e a $3 \mathrm{Km}$ do centro dos aterros, com percurso pelas vias de acesso internas das áreas (Sabesp,1998).

Isto decorre da pouca resistência do lodo ao tráfego de veículos, razão de estudo de todos trabalhos desta tese:

"As tortas de lodo, nos teores que são geradas (30\% a $40 \%$ de MS), não apresentam resistência suficiente para submeter-se ao processo de compactação no interior das células de disposição do aterro, nem mesmo com energia reduzida" (Sabesp, $1998,9.2 .4$ )

\subsection{A cal como aditivo}

Conforme a construtora irlandesa Clogrennane Lime Limited (Clogrennne, 2002), a estabilização de solos usando cal $^{\bullet}$ tem sido empregada usualmente em muitos paises para modificar e estabilizar base de rodovias. Solos argilosos são os que reagem mais favoravelmente ao uso de cal como aditivo. Trata-se de processo que data da antiguidade, pois partes da via Apia em Roma foram estabilizadas com este aditivo e estão resistindo ao tráfego 2000 anos depois.

\footnotetext{
- Estabilização aqui deve ser entendida como geotécnica e não no sentido usualmente empregado pelos sanitaristas, de estabilização da degradação biológica.
} 
A cal reduz a plasticidade, muda as relações de umidade-densidade, visualmente muda a estrutura do solo e altera sua resistência. A estabilização "in-situ" reduz a importação de agregados, o volume de bota-fora (substituição de material da base), o tráfego de caminhões e os custos de construção. Embora irlandesa a construtora ressalta que a calagem de solos nos últimos 50 anos têm sido feita principalmente nos EUA (40 milhões de toneladas de solo foram estabilizadas em 2001).

Avanços recentes desta tecnologia estão sempre sendo alvo de debates em seminários, como os de setembro de 2002 em Dublin e Cork.

Quando solos argilosos são estabilizados com cal em quantidade suficiente para estabilizar o solo, e não apenas modificá-lo, as resistências à compressão podem se tornar de cinco a vinte e cinco vezes maiores do que às dos solos não estabilizados, segundo o Prof. Dr. Dallas N. Little, da universidade do Texas em Austin e pesquisador sênior do Texas Transportation Institute (Clogrennane, 2002). Dr. Little adverte, entretanto, que "solos ricos em orgânicos podem ter estabilização dificil com cal porque as moléculas orgânicas tendem a absorver cálcio".

A estabilização ocorre como resultado de reações de carbonatação e pozolânicas, com a velocidade de reação das pozolânicas controlada pela temperatura. A cal reage com os solos minerais para formar compostos parecidos com cimento, como silicatos e aluminatos de cálcio, responsáveis por mudanças substanciais na resistência e durabilidade.

A cal usada como aditivo na construção de rodovias endurece o revestimento da subbase e aumenta continuamente sua resistência, o Índice Suporte Califórnia e a durabilidade. É também usada, seja como óxido de cálcio ou como hidróxido de cálcio, para secar mais rapidamente o solo molhado, propiciando uma base firme para trabalho, resistente contra a penetração de umidade posterior. 
Como ilustrado no site da construtora irlandesa, a seção transversal da pista do "Bush Intercontinental Airport" em Houston, Texas, mostra que a sub-base foi estabilizada com $60 \mathrm{~mm}$ de cal, sobre ela tendo sido compactado um aterro de $600 \mathrm{~mm}$, estabilizado com cal, sobre o qual foram sucessivamente compactadas três camadas de $166 \mathrm{~mm}$ cada de cimento misturado com cinzas (fly ash). A sub-base e base compõe a sustentação denominada LCF (lime-cement-fly ash). Sobre a estrutura LCF construiu-se o pavimento de $75 \mathrm{~mm}$ do asfalto da pista.

Para as cinco ETE's da RMSP a recomendação do plano diretor de lodos foi de que as tortas desidratadas mecanicamente recebessem cal virgem quando chegassem ao aterro exclusivo, devendo também receber granulados de lodos secos termicamente e cinzas da incineração do lodo se um dia forem disponiveis.

\subsection{O Absorsol e outros aditivos minerais}

A norma brasileira vigente recomenda que "a descarga de lodo no leito de secagem não deve exceder a carga de sólidos em suspensão totais de $15 \mathrm{~kg} / \mathrm{m}^{2}$ de área de secagem, em cada ciclo de operação" (NB - 570, 1990, item 7.6.5). Lima et al, 1999, entretanto, mencionam terem conseguido 25 a $30 \%$ de sólidos, após um ciclo de 35 dias, com uma taxa de $19 \mathrm{~kg} \mathrm{ST} / \mathrm{m}^{2}$, enfatizando que usaram taxas além das recomendadas pela alta concentração inicial do lodo do fundo de lagoas anaeróbias, entre 7 e 10\% ST.

Também com o silico-aluminato de cálcio e magnésio, Absorsol, tem sido possível o emprego de taxas de aplicação acima da recomendada na norma. Os experimentos foram feitos para lodos de algumas ETA's e ETE's em leitos de secagem em escala piloto, obtendo-se teores de sólidos entre 40 e $50 \%$ com taxas de aplicação de lodo no leito de até $50 \mathrm{~kg}$ de SST $/ \mathrm{m}^{2}$ e ciclos de secagem de 15 a 40 dias (Saragiotto, 1998).

\footnotetext{
• Saragiotto, LFR. Comunicação pessoal. 1998.
} 
O mineral ativo do Absorsol é a montmorillonita associada a diatomita. Esta última, embora inerte quanto à troca catiônica, garante a permeabilidade quando junto da montmorillonita, porque evita que ela forme uma pasta por inchamento quando molhada, o que reduziria a probabilidade de trocas cationnicas.

Isto ocorre porque a resistência à compressão a úmido da mistura diatomita mais montmorilonita (Absorsol) é de $92 \%$ de sua resistência a seco, o que favorece a permeabilidade que inexistiria se apenas a montmorilonita fosse adicionada ao lodo (como bentonitas). Além disso, a diatomita tem alta superficie específica $\left(400 \mathrm{~m}^{2} / \mathrm{g}\right.$ ), o que permite a adsorção de compostos orgânicos, especialmente os de grandes moléculas como os hidrocarbonetos, organoclorados e a maioria dos compostos odoríferos do lodo.

O conjunto de propriedades do Absorsol, apregoado pela sua representante comercial Alphageos como capaz de: eliminar odores; diminuir a atratividade do lodo para vetores; reduzir o desprendimento de amônia; encapsular metais pesados impedindo sua lixiviação e solubilização; encapsular compostos perigosos, como hidrocarbonetos, organoclorados, hidrocarbonetos policíclicos aromáticos, benzo- $\alpha$-pireno; acelerar a secagem após lançamento do lodo ou torta no aterro ou em leitos de secagem, fez com que parecesse razoável experimentá-lo como um dos aditivos indispensáveis para construção dos aterros multiniveis.

Uma das objeções usuais à durabilidade do encapsulamento é que condições ambientais ou climáticas adversas poderiam rompê-lo, liberando o produto perigoso na natureza. Entretanto, deve ser reconhecido que nenhum fenômeno natural se compara à agressividade do ensaio de lixiviação (NBR 10.005), e tem sido constatado que lodos, tratados com Absorsol, não liberam os contaminantes após a lixiviação de laboratório (Saragiotto, 1998) . Quanto à durabilidade deste encapsulamento, como se trata de um

\footnotetext{
- Saragiotto, LFR. Comunicação pessoal. 1998.
} 
silicato e não de uma resina orgânica (por exemplo, turfas tratadas, pela alta CTC e superficie específica, muito usadas para encapsulamentos temporários até o momento da incineração do resíduo), sua eficácia não diminui com a passagem dos anos.

O atual uso de polímeros no précondicionamento da torta estimula a troca catiônica e a absorção de compostos perigosos, pois a floculação aumenta a probabilidade de contato entre os minerais do Absorsol e os metais ou compostos a serem encapsulados. Com a melhoria da floculação, o encapsulamento e a troca cationnica entre metais e compostos indesejảveis são favorecidos.

Entretanto, como a tese demonstrará, a principal propriedade que o aditivo ao lodo deve possuir para fins do aterro exclusivo é a de aumentar a resistência do aterro ao tráfego de veiculos. Neste particular a cal virgem demonstrou ser mais eficaz. Esta é a condição primeira e última para tornar o aterro exeqüivel e que precisaria ser melhorada com uso de cal virgem antes do lançamento da torta no aterro. O Absorsol poderia contribuir para a produção de chorumes menos poluentes e para evitar odores ofensivos no aterro, como será discutido nas páginas seguintes.

A Figura 2 ilustra a distribuição da água intersticial nos lodos, cuja diminuição é o objetivo das operações de filtração. 


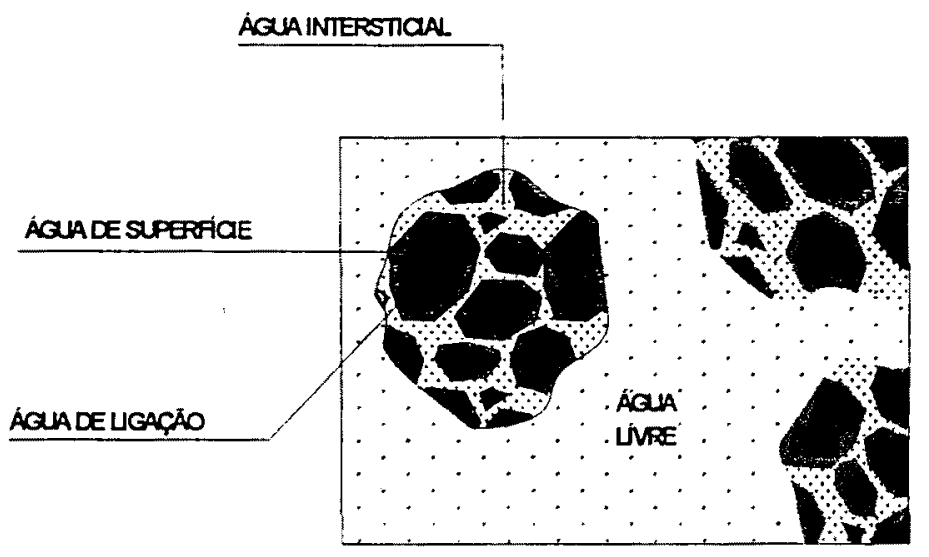

Figura 2 Distribuição da água intersticial no lodo

Fonte: TSANG \& VESIIND, 1990, citado por Bisogenin,JLM,1999

Grandin, 1992, citado por Miki et al., 2001 conceitua este fracionamento da água presente nos lodos em água livre; interflocos; adsorvida nos flocos; interpartículas; adsorvida nas partículas e água da própria partícula. A água livre é a que se separa em primeiro lugar, pela simples sedimentação dos flocos de lodo quando a massa líquida entra em repouso. A presa entre os flocos (interflocos) é também removida com facilidade por pressão ou vácuo.

A desidratação rápida a vácuo, por exemplo, foi pesquisada com sucesso em Bodenkultur, Vienna, onde lodo tratado com polimeros foi espalhado sobre uma placa perfurada e separado da água interflocos sob uma pressão de 0,4 bars. (Haberl e Salzer, 1992).

A água adsorvida no floco também exige adequada pressão ou vácuo para ser liberada, segundo Grandin, tanto que quando o lodo se fragmenta a parcela de água adsorvida é 
dificil de ser identificada. A água interpartículas já exige ruptura dos flocos para ser separada, requerendo pressões elevadas ou vácuo atuante sobre as partículas fragmentadas. A adsorvida na partícula fica presa por tensão superficial ou sucção capilar e dificilmente se separa por meios mecânicos.

Finalmente, a água intrinsecamente ligada na partícula está quimicamente ligada às células ou fisicamente presa às partículas orgânicas, só sendo viável sua separação pela combustão. Ainda segundo Grandin, 1992, não existem técnicas capazes de discriminar numa massa de lodo estes diferentes tipos de aprisionamento da água nas partículas e muitas pesquisas tem sido realizadas neste sentido.

Com relação ao Absorsol, suas características físico-químicas podem ser vistas no ANEXO A e a Tabela 1, na seqüência, compara as características deste produto com as de outros condicionadores minerais naturais. 
Tabela 1 - Características de condicionadores minerais naturais

\begin{tabular}{|c|c|c|c|c|}
\hline \multirow{2}{*}{ Característica } & \multirow{2}{*}{ Unidades } & $\begin{array}{c}\text { Zeólito natural } \\
\text { dos EUA } \\
\text { Agricolite (1) }\end{array}$ & $\begin{array}{c}\text { Zeólito natural } \\
\text { do México (2) }\end{array}$ & $\begin{array}{c}\text { Silico aluminato } \\
\text { de cálcio e } \\
\text { magnésio } \\
\text { Absorsol (3) }\end{array}$ \\
\cline { 2 - 5 } & $\begin{array}{c}\text { AMC Agricola } \\
\text { Metals Corporation }\end{array}$ & $\begin{array}{c}\text { Promotora } \\
\text { Nacional }\end{array}$ & $\begin{array}{c}\text { Alphagcos/Sol } \\
\text { Mincrales do } \\
\text { Brasil }\end{array}$ \\
\hline Tipo de mincral & & clinoptilolita & clinoptilolita & $\begin{array}{c}\text { Silico aluminato } \\
\text { de cálcio e } \\
\text { magnésio }\end{array}$ \\
\hline Ocorrência & & natural & natural & natural \\
\hline SiO2 & $\%$ & 64,7 & 64 & 67,92 \\
\hline MgO & $\%$ & 1,10 & 0,66 & 2,17 \\
\hline Al2O3 & $\%$ & 14,16 & 12,62 & 12,27 \\
\hline CaO & $\%$ & 2,0 & 2,03 & 1,62 \\
\hline Fe2O3 & $\%$ & 1,8 & 2,28 & 3,68 \\
\hline K2O & $\%$ & 3,4 & 5,3 & 0,42 \\
\hline Grânulos & $\mathrm{mm}$ & & $2 \mathrm{a} 4$ & 2 a 4 \\
\hline Cor & & branca & & branca \\
\hline Abrasão & & 20 & & nula \\
\hline CTC & $\mathrm{Meq} / 100 \mathrm{~g}$ & & & $48,7 \pm 5$ \\
\hline $\mathrm{pH}$ & & 7,5 & & 7,5 \\
\hline Massa especifica & $\mathrm{g} / \mathrm{cm} 3$ & $2,23 \mathrm{a} 2,28$ & & 2,3 \\
\hline Superficic especifica & $\mathrm{m} / \mathrm{g}$ & & & 400 \\
\hline Embalagem & $\mathrm{Kg} / \mathrm{saco}$ & 25 & & 25 \\
\hline Agrom & & & & \\
\hline
\end{tabular}

(1) Agricola Metals Corporation

(2) Promotora Nacional SA

(http://www.watertechnology.net/contractors/wastewater/promotora/index.html\#promotora3)

[21.01.03]

(3) Alphageos Tecnologia Aplicada S.A.

(http://www.alphageos.com.br/gestao.htm) [21.01.03]

Os zeólitos são muito utilizados na petroquímica, na adsorção e na indústria de detergentes. Segundo Kirk-Othmer, 1991, adsorção é o termo usado para se descrever a tendência de moléculas de uma fase ambiental fluida aderir à superfície de um sólido. Os adsorventes cristalinos (zeólitos e análogos) tais como silicatos possuem microporos 
cujas dimensões são determinadas pela estrutura cristalina, inexistindo virtualmente uma distribuição de diferentes tamanhos de poros. Os zeólitos são silicatos aluminosos hidratados complexos que podem ocorrer como mineral natural ou serem sintetizados artificialmente. Os cristais dos zeólitos, possuem grande superfície especifica com carga liquida negativa, ou seja alta capacidade de troca de cátions (CTC), o que habilita o zeólito absorver e trocar livremente seus cátions com os do solo circundante. (KirkOthmer, 1991, Promotora, 2002)

A CTC mede o nivel de cargas negativas do solo que irão trocar cátions $\left(\mathrm{Ca}^{2+}, \mathrm{Mg}^{2+}, \mathrm{K}^{+}\right.$, $\left.\mathrm{Al}^{3}+, \mathrm{H}^{+}\right)$com a solução de solo absorvida pelas raizes das plantas. Solos com pequenas partículas possuem alta CTC, pois a relação superficie / volume (S/V) é alta. Como a superficie de uma esfera (partícula de solo) é $S=4 \pi r^{2}$, e como e $V=4 / 3 \pi r^{3}$, dividindo membro a membro obtemos $S / V=3 / r$, ou seja, quanto menor o raio maior a relação $S / V$. Solos onde esta relação é alta expõem maior superfície de cargas por volume de solo e possuem maior CTC. Com alta CTC eles geralmente têm grande reserva de nutrientes minerais. A CTC pode ser dada por $\mathrm{Ca}^{2+}+\mathrm{Mg}^{2+}+\mathrm{K}^{+}+\mathrm{Al}^{3+}+\mathrm{H}^{+}$, onde a soma dos três primeiros cátions é conhecida como soma das bases. Quanto maior ela for e menor a soma dos dois últimos, mais fértil será o solo (Peres, 2002).

A água intersticial da estrutura cristalográfica dos zeólitos constitui um reservatório de longo prazo para as plantas. A maior parte dos zeólitos provem de depósitos de cinzas vulcânicas que se formam em lagos alcalinos. A ocorrência natural traz impurezas que devem ser eliminadas industrialmente para obtenção do produto útil. Os zeólitos são úteis para a eliminação da amônia dos esgotos, eliminação de odores e adsorção de resíduos radioativos como estrôncio e césio. Não apresenta riscos para amimais ou homens. (AMC, 2002)

Os grupos de minerais smectitas, vermiculitas e zeólitos são reconhecidos como os que possuem a maior capacidade de troca cationnica que possa existir com os solos (Dixon, 1991) 
Quanto ao Absorsol, seu mecanismo de encapsulamento consiste em encerrar os contaminantes em células microscópicas de silício (cápsulas pusolâmicas) que se encontram presas por argila, com capacidade de troca iônica. Os contaminantes (cromo, chumbo, níquel, mercúrio, hidrocarbonetos e ácidos) substituem os cátions de intercâmbio, cálcio, magnésio, sódio e potássio. Os elementos com maior carga elétrica são aprisionados prioritariamente, podendo mesmo substituir outros que ficaram presos antes mas que estão em posição inferior na série eletrolítica. Devido a elevada porosidade e capilaridade a quantidade de residuos retidos é muito grande, o que produz uma alteração de coloração do centro para a periferia da massa, desde o branco até o amarelo-marrom, quando a saturação é total. (Bio-Services, 2002).

Segundo a Bio-services, 2002, trata-se de produto totalmente natural, ativado termicamente sem ataque ácido; não é tóxico e nem irritante para a pele; transforma lodos instáveis e/ou contaminados em solo inerte; restitui a permeabilidade do solo e recupera sua oxigenação; favorece o desenvolvimento de bactérias aeróbias e anaeróbias "in-situ"; neutraliza odores pela retenção de elementos voláteis como amoníaco, mercaptanas, tricloros entre outros; diminui o chorume do aterro; rompe cadeias de hidrocarbonetos impedindo a combustão do resíduo com níveis de absorção $250 \%$ maiores do que os da cal, $330 \%$ vezes maiores do que os do cimento e $400 \%$ maiores do que a de cavacos de madeira ("woodchips"); pode ser aplicado manual ou mecanicamente e, finalmente, tem validade ilimitada de armazenamento sem deterioração. Adicionalmente, devido à sua grande superficie exposta e força capilar, reduz os intervalos de tempo para a mistura (diretamente proporcionais à viscosidade do produto) e acelera o microencapsulamento.

Além dos três aditivos minerais, terra, cal e cinzas, o próprio lodo seco termicamente deverá ser usado no aterro. Sua "utilização deveria ser prioritária... por apresentar o melhor aproveitamento da área do aterro”.... (Sabesp 1998, 7.3.1.2) 


\section{OBJETIVOS}

\subsection{Objetivo principal}

O objetivo geral da pesquisa foi o estudo da mistura de aditivos com a torta filtrada do lodo de Barueri, determinando a forma mais adequada para realizar essa mistura e verificando seu comportamento geotécnico após compactação no terreno. Foi também verificada se as tortas da ETE Barueri poderiam ser aplicadas na agricultura, dentro da normatização vigente na época para este fim.

\subsection{Objetivos especificos}

Constituiram objetivos especificos os seguintes pontos:

- Verificar a viabilidade de misturar aditivos com tortas de lodo de filtro prensa sem que ocorra aderência excessiva da mistura no equipamento (como já experimentado quando betoneiras comuns foram usadas).

- Verificar se as taxas de aplicação de cal virgem no lodo, recomendadas pelo plano diretor através de experimentos em escala de bancada, seriam ou não confirmadas nas pistas experimentais a construir no pátio da ETE Barueri, tendo como indicador de aceitabilidade a resistência ao tráfego de veículos secundários de terraplenagem e maquinário de pequeno porte para espalhamento do lodo (veículos transportadores das tortas, pás mecânicas de pneu e tratores de esteiras pequenos, tipo D-4 da Caterpillar).

- Verificar os efeitos na trabalhabilidade, sanidade e resistência da pista experimental construída quando fosse usado um silico-aluminato de cálcio e magnésio (Absorsol) misturado à torta de lodo em acréscimo a cal virgem. 


\section{REVISÃO DA LITERATURA}

\subsection{Disposição de lodos em aterros}

$\mathrm{O}$ aterro é considerado a opção menos favorável quanto ao gerenciamento da disposição de um resíduo, mas é altamente atraente pela capacidade de resolver grandes volumes a dispor. Nos próximos 10 anos deverão ocorrer grandes modificações no mundo todo devido a pressões contrárias à esta prática (Banks e Heaven, 2001). Os dois autores conceituam a seguinte classificação para disposições do lodo no solo, além dos aterros:

- "Surface impoundments" ou armazenamentos superficiais.

- "Lagoons" ou lagoas, salvo quando pertencentes ao tratamento quando então não são consideradas como disposição de lodos.

- "Waste piles" ou pilhas de resíduos.

- "Dedicated disposal sites", ou locais reservados para disposição, usualmente dentro da ETE,

- "Dedicated beneficial use sites" ,ou locais reservados para uso útil, onde o lodo é aplicado a taxas maiores que a agronômica em culturas específicas contando com um bom gerenciamento durante sua disposição.

O aterro exclusivo ('monofill' nos EUA ou 'mono-deposit' na UE), recebe apenas um tipo de material (lodo no caso) existindo o controle sobre a disposição deste material desidratado em depressões, onde ele contido por diques e/ou pelo próprio terreno. Distingue-se das pilhas de residuos (“waste piles"), que são apenas pilhas de lodo desidratado colocados na superficie, sem cobrimento diário ou final. (Déak, 1997, Banks e Heaven, 2001).

Já a aplicação no terreno é o nome reservado para a prática de aplicar o lodo a taxas agronômicas compatíveis com as necessidades de condicionar o solo ou de fertilizar 
plantios, não sendo usado o termo de disposição final de lodos neste caso (Banks e Heaven 2001).

Nos EUA, a quantidade de lodo disposta em aterros é de $17 \%$ ou 1,2 milhões de t/ano, acrescida ainda de 0,2 milhões de t/ano de lodo tratado para a cobertura diária ou final de aterros. $\mathrm{Na}$ agricultura aplica-se $41 \%$, ou 2,8 milhões de $\mathrm{t}$ /ano, e em outros usos úteis, 0,5 milhões de tano. (Usepa, 1999).

$\mathrm{Na}$ União Européia foi estimada uma produção de lodo não desidratado de 230 milhões de toneladas, em 1993. Na Alemanha, 25\% da produção era usada na agricultura, $65 \%$ disposto em aterros e $10 \%$ incinerados. Na Suiça as cifras correspondentes eram 50, 30 e 20 , respectivamente, enquanto na França eram 55, 25 e 20. No futuro espera-se que a preferência pelos aterros diminua e que só sejam escolhidos quando não houver nenhuma alternativa disponivel. As diretrizes de hoje voltam-se para a agricultura e a incineração (Déak, 1997).

A maior parte dos biossólidos dispostos no terreno têm co-disposição com resíduos sólidos municipais (RSM), o que nos Estados Unidos é regulamentado pela "Part 258 Landfill Rule" e não pela "Part 503 Sludge Rule". O lodo disposto no aterro municipal é utilizado como cobertura diária ou final do aterro. No último caso é colocado sobre uma camada de encerramento de argila impermeável e serve de berço para um recobrimento vegetal. Já na cobertura diária, substitui a camada de $15 \mathrm{~cm}$ de terra ao final de cada dia de operação, ou a intervalos mais freqüentes, se necessário, controlando o surgimento de vetores, a ignição espontânea, os odores, o lixo esvoaçante e as aves de rapina. Outros materiais de cobertura poderão ser aprovados se o proprietário do aterro ou o operador demonstrarem que este, uma vez usado na espessura proposta, é capaz de controlar os mesmos inconvenientes acima indicados, sem riscos à saúde humana ou ao meio ambiente (Part $258 \S 258.21$ ). 
Nos experimentos conduzidos nesta tese foi notado um forte desprendimento de amônia na pista que recebera apenas cal como aditivo, fato evitado quando o Absorsol foi também adicionado à cal e ao lodo antes do lançamento na pista. Este assunto será novamente abordado na apresentação dos ensaios de campo, mas o gás de amônia pode ser sufocante e de extrema irritação aos olhos, garganta e trato respiratório. Dependendo do tempo e nível de exposição, podem ocorrer efeitos que vão de suaves irritações a severas lesões no corpo, devido a sua ação cáustica alcalina. Exposições a altas concentrações - a partir de 2500 ppm por um periodo de $30 \mathrm{~min}$. - podem ser fatais. (Total Química, 2001).

Uma vez concluído, o aterro deve receber uma cobertura final, cujo objetivo é o de evitar a infiltração das águas de chuva diretamente precipitadas e a erosão. A chuva não incidindo diretamente sobre o aterro já terá sido desviada por uma drenagem de contorno (valeta de proteção) em todo seu perimetro. Segundo a 'Part 258' (§ 258.60), o sistema de cobertura deve ser construído de tal forma que sua permeabilidade seja menor do que a menor das permeabilidades seguintes: a do revestimento da base do aterro; a do subsolo natural local e a de valor igual a $1 \times 10^{-5} \mathrm{~cm} / \mathrm{s}$. Além disso, a infiltração deve ser minimizada por uma cobertura de terra de $46 \mathrm{~cm}$ (18") e deve ser colocada uma camada de $15 \mathrm{~cm}$ de terra vegetal recobrindo estes $46 \mathrm{~cm}$, para cultivo de plantação nativa.

A disposição de biossólidos no terreno é definida pela "Part 503" como o uso de uma área só para biossólidos, excluindo os dispostos apenas para fins de armazenamento (geralmente menos de dois anos) ou de tratamento, como as lagoas de lodo para redução de patógenos. Inclui a disposição em aterros exclusivos ('monofills' ou aterros somente para biossólidos), a disposição em pilhas permanentes e as lagoas de disposição, quando inexistir a transitoriedade do depósito, contrariamente ao caso anterior. A Usepa frisa que a diferença entre a disposição e a aplicação no terreno reside na taxa de aplicação (Usepa, 1999, p. 22), porque se for maior do que a necessidade agronômica da cultura a quantidade de nitrogênio no solo pode se tornar excessiva, existindo risco de contaminação do aqüifero. Neste caso, deverão ser seguidas as práticas de 
gerenciamento previstas na 'Part 503' para disposição superficial, inclusive fazendo-se o monitoramento do aqüifero. Se o aplicador reduzir a taxa de aplicação ou se mudar de cultivo, passando de um plantio de baixa para um de alta demanda de nitrogênio, eventualmente, poderá se enquadrar como praticando a aplicação no terreno, devendo então atender os limites para metais, patógenos e reduzida atratividade a vetores da "Sludge Rule".

Para que se tenha uma idéia da complexidade das diversas interpretações possiveis é interessante examinar algumas discussões havidas no fórum mantido pela WEF, onde administradores e responsáveis por serviços de saneamento de qualquer parte podem expor suas dúvidas e receber respostas de outros freqüentadores deste forum na Internet.

Em julho de 2000, por exemplo, a seguinte consulta foi colocada no fórum:

Encerramos as operações de uma ETE muitos anos antes da entrada em vigor da 503. Naquela época, a prática aceita era a disposição superficial, ou seja, colocação do lodo do tratamento numa lagoa de lodo. Os lodos secaram com a passagem dos anos e o depósito original não recebeu nenhuma intervenção desde então. Estamos considerando a possibilidade de utilizar o local como bota-fora de escavações de solos inservíveis para reaterros na construção civil. Não estamos familiarizados com detalhes da 503. Perguntamos se a questão se encontra no âmbito dela e se porventura existem pontos nebulosos que poderiam nos trazer problemas se não fossem observados.

A resposta recebida reflete as sutilezas da legislação norte-americana:

Se você está pensando em completar a lagoa com bota-fora ou resíduos de construção você deve consultar o manual de projetos da EPA "Design Manual for Surface Disposal of Sewage Sludge and Domestic 
Septage"(EPA/62/R-95/002). Se você não estiver familiarizado com o encerramento de aterros (essencialmente o que você tem hoje é um aterro exclusivo abandonado), você deve usar os serviços de um consultor para avaliar as condições locais e os regulamentos do seu estado. Os velhos biossólidos depositados poderiam ser lançados num aterro municipal se você porventura pretende retirá-los. Esta pode ser sua opção menos complicada. Agora, se você pretender dispô-los no terreno, você deverá satisfazer as exigências da 503. A densidade de patógenos não ofereceria problema, mesmo assim você deveria fazer a verificação de coliformes, mas estou certo que o resultado não lhe apresentará qualquer obstáculo. Você deverá ainda atender a baixa atratividade a vetores e isto pode ser capcioso. Seus biossólidos certamente apresentarão baixa atratividade, mas, infelizmente, a legislação ignora isto.

Se houvesse meios de você determinar qual a concentração de sólidos voláteis que saía da estação (e estou apostando que você não digeria o lodo), seria possivel verificar se ocorria uma redução de $38 \%$ nos SV. Se você não puder demonstrar que a redução nos SV atingiu o requerido, você poderia aplicar o lodo no terreno a uma taxa aprovada para que a terra fosse arada. Penso que seria necessária uma licença do órgão ambiental para isto, e seria também preciso localizar plantadores interessados em usar o biossólido.

Antes disso você deve analisar o biossólido e demonstrar que os limites para metais estão sendo atendidos. Não invejo seu problema. Talvez a melhor opção seja a co-disposição com o lixo urbano. Não seria surpreendente que seu lodo fosse classe $A$, se atendesse os limites para metais. O problema é que você precisaria demonstrar isso, o que exigiria provar que os virus, parasitas e Salmonellas $s p$. foram adequadamente reduzidos. Pode ser compensador se a quantidade de biossólidos for muito 
grande e se você dispuser de recursos financeiros para as análises. (Farrell, 2000)

Por mais cuidadosa que seja a localização e a operação de um aterro, sempre deve ser levada em conta a inevitável ocorrência de alguma poluição do subsolo. Esta a razão pela qual as áreas com vulnerabilidades geológicas devem ser evitadas no processo de escolha do local, como aquelas sobre terrenos calcários ou os altiplanos com solo de pedregulhos situados sobre camadas de aqüíferos subterrâneos, ambos de uso especificamente desaconselhado. Outro fator a salientar é que o aterro propriamente dito deve ser localizado num local seco, acima do nível d'água do lençol freático. (Déak, 1997)

\subsection{Tipos de aterro}

Existem dois tipos de aterros de lodo de esgotos possíveis: os aterros exclusivos, onde somente o lodo é depositado, e os aterros mistos nos quais os lodos são dispostos em conjunto com o lixo municipal em aterros sanitários.

\subsubsection{Aterros exclusivos de lodo}

Segundo Déak, 1977, a maior restrição para o estabelecimento de um aterro exclusivo em clima temperado é a desidratação adequada das tortas de lodo, que não deveria ser inferior a $35 \%$ ST sob pena de tornar inviável o transporte e o manuseio do lodo.

Nogueira e Santos, 1995, realizaram ensaios no pátio da ETE Barueri e constataram que mesmo com $40,1 \%$ ST a torta pré-condicionada com cal e cloreto férrico era incapaz de suportar o tráfego de um trator D-4 e de um caminhão de 6 t. Apenas depois de uma camada de terra de $50 \mathrm{~cm}$ sobre as tortas confinadas numa célula circundada por diques, de $5 \times 11 \times 0,6 \mathrm{~m}$, foi possivel o trafego de um BobCat de $1.200 \mathrm{~kg}$ de peso, que com sua caçamba, pneus de borracha e acessórios, conseguiu transportar, dispor e espalhar a 
terra sobre o lodo que fora colocado na célula, compactando-a sem afundamento nas suas passagens. O lodo foi colocado em pilhas na célula, formando uma "superficie lunar”, incapaz de resistir ao tráfego de quaisquer veículos, o que só foi possivel após a camada de terra mencionada.

Deve ser ressaltado que o processo concebido pela Sabesp para os aterros exclusivos (Sabesp, 9.2.3), pressupõe a mistura de cal e de lodo granulado seco termicamente às tortas de lodo com 30 a $40 \%$ ST que serão lançadas na célula do aterro multinivel. Tratase de uma situação mais favorável que a do ensaio mencionado, que visava obter parâmetros para a construção de aterros emergenciais, não multinivel, numa área vizinha a Barueri, até que os aterros, ora prestes a serem construidos, entrassem em operação.

Dérek recomenda que a consistência do lodo seja verificada pelo teste de cisalhamento, e julga como equipamentos mais adequados para desidratação os filtros prensa e as novas gerações de centrífugas, teoricamente capazes, segundo o autor, de alcançar ou exceder os $35 \%$ ST requeridos, após condicionamento com cal e cloreto férrico ("after lime-iron salt conditioning"). Cita como exemplo o monofill a $20 \mathrm{~km}$ de Budapest, no municipio de Fótcsomád, tido como o aterro exclusivo mais avançado existente na Europa Central, e que recebe tortas de filtro prensa pré-condicionadas com cal e cloreto férrico a 40 - 50\% ST da Northem - Budapest WWTP. (Dérek, 1977 p38)

Dentre os controles recomendados por Dérek na operação de um aterro exclusivo devem ser destacados os que precisam funcionar em harmonia uns com os outros:

- A organização do depósito de tortas no aterro

- O movimento dos caminhões de transporte

- A movimentação do material no depósito

É ainda recomendada atenção à largura da camada de lodo, essencialmente dependente de sua consistência; o armazenamento e a colocação da camada de terra de cobertura 
(solo) para controle de odores e contaminações mediante vetores; a coleta do percolado e da água pluvial, cuja reunião e disposição (ou tratamento) devem ser periodicamente verificados; a contaminação do aqüifero, que sendo constatada exigirá modificação da tecnologia da disposição. Além destas regras operacionais devem ser obedecidas uma ampla gama de procedimentos de saúde ocupacional dos operadores, regras higiênicas e de segurança do trabalho.

Embora em menor quantidade do que nos aterros mistos, deve ser esperada a formação de biogás nos aterros exclusivos, segundo Dérek, 1997. O biogás conterá $50-60 \%$ de metano e 40 - 50\% de dióxido de carbono, além de pequenas proporções de outros gases.

O metano é considerado perigoso e sua liberação na superficie do aterro deve ser verificada e controlada, sendo da maior importância evitar o acumulo do gás em ambientes confinados, como por exemplo, em poços de visita do sistema de drenagem.

\subsubsection{Aterros mistos de lodo}

O aterro sanitário é definido uma "forma de disposição final de resíduos urbanos no solo, através de confinamento em camadas cobertas com material inerte, geralmente solo, segundo normas operacionais específicas, de modo a evitar danos ou riscos à saúde pública e à segurança, minimizando os impactos ambientais" (PN 1:63.01 - 001/1987, "Degradação do Solo - Terminologia", ABNT, citada por Fuzaro, 1998, p.3).

Fuzaro, 1998 menciona que os aterros sanitários apresentam como vantagens um custo de investimento muito menor do que o requerido por outras formas de tratamento de resíduos; um custo de operação também menor do que as alternativas que contemplam tratar o lixo; o fato de tratar-se de um método completo, não apresentando rejeitos que se destinem a outras instalações; simplicidade e flexibilidade operacionais, sendo capaz de operar mesmo ocorrendo flutuações nas quantidades de resíduos a serem aterradas. 
Como desvantagens, Fuzaro aponta tratar-se de uma forma de armazenamento no solo, não de tratamento dos residuos; requer áreas cada vez maiores; é uma operação sujeita às condições climáticas e apresentando risco de contaminação do solo e da água subterrânea.

A parte predominante num aterro sanitário municipal é constituida pelo lixo classe 2 do municipio. O lodo pode ser agregado numa proporção usualmente de 20 - 25\% (Dérek, 1977).

Esta proporção é variável de acordo com a operação do aterro, que se preocupa com as condições de mistura e espalhamento (dependentes principalmente da umidade do lodo) e com o esgotamento do depósito municipal (dependente da área disponível para operação do aterro).

Em 1994 a Sabesp realizou um convênio com a PMSP pelo qual ela recebia o chorume dos aterros municipais para tratamento junto com os esgotos das ETE's de Barueri e Suzano, enquanto a prefeitura se obrigava a receber não mais do que $5 \%$ em peso de seu volume diário de lixo em tortas de lodo de ambas ETE's. A condição necessária para que a codisposição com os resíduos sólidos urbanos seja aceita pela prefeitura é que o lodo seja enquadrado como "resíduo não perigoso", ou resíduo "Classe2", conforme a norma brasileira de classificação de resíduos sólidos NBR 10.004, de 1987. (Santos, 1996)

Os requisitos de desidratação das tortas para co-disposição não são tão severos quanto os exigidos para os aterros exclusivos de lodo porque a capacidade higroscópica do lixo é alta. Para que haja atividade microbiológica adequada na massa do aterro é necessário que as tortas de lodo estejam na faixa de $35-40 \%$ ST. Ocorre então a degradação biológica dos compostos orgânicos que, ao se estabilizarem, formam o gás metano, cuja coleta e administração é praticamente compulsória (Dérék, 1997). 
Alguns dos principios que regulam os aterros mistos, segundo a regulamentação alemã (citada por Dérek, 1997), são relacionados a seguir:

- O lodo só pode ser lançado depois que foi formada uma camada de lixo de altura mínima igual a 3 (três) metros, devendo ser evitado o espalhamento continuo do lodo sobre o lixo.

- Existem três métodos construtivos em função da maneira com que o lodo foi misturado ao lixo: os depósitos podem ser feitos empilhando o lodo, caso em que sua quantidade máxima deve ficar em torno de $20-25 \%$ (base úmida) da quantidade de lixo, ou podem ser mistos ou, finalmente, podem ser feitos em dois ou três níveis, caso em que o lodo só pode participar sendo cerca de $10 \%$ da quantidade de lixo.

- A descarga do lodo deve ser imediatamente seguida pelo recobrimento com lixo.

- A formação de gases durante a disposição ocorre, mas não é preocupante devido a grande área de dispersão ainda existente enquanto os resíduos estão sendo colocados. Entretanto a quantidade formada deve aumentar significativamente depois de concluído o processo de deposição e uma vez feito o recobrimento com solo. Estes gases devem ser coletados e utilizados se possivel. Se não for possível seu uso útil sua ventilação e dispersão deve ser assegurada de alguma outra forma (por exemplo, por chaminés de ventilação e queima dos gases expelidos).

- A água percolada através dos resíduos depositados e das camadas de lodo, ou o chorume do aterro, tem vazão em torno de 0,01 a $0,1 \mathrm{~L} / \mathrm{s}$, DBO altíssima da ordem de 50 a $60 \mathrm{mil} \mathrm{mg/L} \mathrm{e} \mathrm{um} \mathrm{conteúdo} \mathrm{de} \mathrm{amônia} \mathrm{alcançando} \mathrm{vários} \mathrm{milhares}$ de $\mathrm{mg} / \mathrm{L}$. 
Segundo Dérek o chorume pode ser tratado ou recirculado para o aterro, embora esta última pratica não seja permitida em alguns paises. Entretanto este último método traz dois beneficios: aumenta a quantidade de água favorecendo a formação dos gases e reduz a carga orgânica pelo aumento da permanência do líquido no aterro.

Lue-Hing et al, 1992, mencionam que os aterros sanitários municipais nos Estados Unidos devem ser diariamente cobertos com uma camada de terra para evitar vetores, odores, riscos de contaminação atmosférica (devido ao vento) e do aqüífero (devido ao escorrimento superficial provocado pela chuva). Estes autores consideram perfeitamente aceitável usar lodos do tratamento de esgotos para tal cobertura, desde que com concentração de sólidos igual ou superior a 50\%, apontando que, nesses casos, o lodo tem um comportamento semelhante ao solo argiloso, constitui uma barreira que evita a penetração de vetores no aterro, desde que se trate de lodo estabilizado biologicamente, i.e., com seu teor de sólidos voláteis reduzido previamente.

Farrell et al do Laboratório de Pesquisas e Desenvolvimento da Usepa de Cincinnati, Ohio, citado por Lue-Hing p.348, afirmam que o acréscimo de lodo de esgotos aos aterros melhora a qualidade do chorume, como comprovado durante 20 meses por células de teste, onde as que receberam lodo de esgotos produziram um chorume de $1500 \mathrm{mg} / \mathrm{L}$ de DQO enquanto a vizinha, sem o lodo como aditivo, liberou um chorume de $30.000 \mathrm{mg} / \mathrm{L}$. Adicionalmente, enfatizam os autores, as concentrações de metais como cádmio, cromo, cobre, chumbo, níquel, ferro e zinco foram mais baixos no primeiro caso do que no segundo. Enfatizam que os ensaios realizados se contrapões a crença justamente oposta, de que o lodo no aterro contribui para piorar a qualidade do chorume: o oposto é verdadeiro, segundo este grupo da Usepa. 


\subsection{Aterro exclusivo de lodo projetado para a RMSP}

Os aterros de lodo ao longo da via Anhanguera ocuparão à leste da rodovia 56,2 ha, dos quais 18,6 serão destinados à disposição dos lodos. Do lado oeste da pista a propriedade terá 63,5 ha com duas áreas de disposição, uma de 18,6 ha (oeste 1) e outra de 21,0 ha (oeste 2).

Com o objetivo de viabilizar o tráfego de veículos necessários à construção e operação das células, plano diretor citado propõe resolver a deficiência da capacidade de suporte do lodo pelo uso de aditivos diversos, conforme a natureza das tortas que chegarem ao aterro, desde a forma que mais volume exigirá por tonelada de lodo depositada (30 a $33 \%$ ST e mistura com cal na proporção $\mathrm{L} / \mathrm{Cal}=1 / 0,20$ ), até a forma que melhor aproveitaria o volume útil do aterro (cinzas de incineração). Imediatamente antes das cinzas está sugerida a segunda forma mais rentável, que é a mistura da torta a $40 \%$ ST com lodo granulado seco termicamente e com cal virgem, nas quantidades respectivas de 1:0,77:0,175. (Sabesp, 1998, p.143)

Pode ser lembrado que a segunda forma mais rentável de aproveitamento do volume do aterro, acima citada, faz uso dos excedentes da produção de lodo granulado que começou a ser produzido em 2002 na central de secagem térmica da ETE São Miguel. Tal forma de redução de volume e higienização do lodo é talvez a melhor e mais aceita mundialmente para áreas metropolitanas como a de São Paulo. A secagem térmica dos lodos é uma realidade com impressionante taxa de aceitação nos últimos anos (Santos, 1993).Os excedentes fatalmente ocorrerão na entre-safra agricola, pois a produção do lodo é continua e a dos fertilizantes não. Como exemplo, Santos, 1996, menciona:

A maior instalação peletizadora de lodo de ETEs do mundo começou a operar em agosto de 1993 em Nova York. São 300 toneladas por dia, base seca, sendo processadas em seis linhas de secagem térmica para $50 \mathrm{t} / \mathrm{dia}$ 
cada, as quais recebem o lodo desidratado por centrífugas com a concentração de sólidos entre 25 e $27 \%$. O lodo centrifugado provem de oito centrais desidratadoras, onde um total de 55 centrifugas são operadas pela Wheelabrator Technologies Inc, sucessora da New York Organic Fertilizer Company. Os lodos centrifugados e os secos térmicamente, a $95 \%$ de sólidos, são transportados para vários pontos do país, como pastagens no Texas, campos de trigo no Colorado, laranjais na Flórida, aterros no Estado de Virgínia, recuperação de áreas degradadas limitrofes à cidade e aterros de residuos perigosos na Pensilvânia (Santos 1996, p.3)

Segundo a Sabesp, 1998 e o EIA do aterro sanitário exclusivo (Sabesp, 1995) as células serão superpostas como indicado na figura apresentada anteriormente, com dimensões médias de $50 \times 100 \times 6 \mathrm{~m}$, circundadas por diques de terra com taludes $\mathrm{V}: \mathrm{H}=1: 1,5$. No fundo possuirão uma camada de areia para drenagem do lixiviado e sobre a camada final de enchimento de cada $6 \mathrm{~m}$ de altura, solo compactado para evitar o ingresso de água pluvial percolada durante a construção e nova camada de areia para drenagem dos gases.

As células inferiores de cada pilha em contato com o solo terão barreiras múltiplas de proteção do aqüífero, descritas a seguir de baixo para cima, no sentido da construção:

- Inicialmente, na base, constituida de drenos profundos e galeria visitável para a coleta de águas do lençol transversal ao maciço do aterro;

- sobre ela virá uma camada de argila compactada com $\mathrm{k}=10^{-7} \mathrm{~cm} / \mathrm{s}$,

- a argila será protegida na parte superior por uma manta de polietileno de alta densidade de $2 \mathrm{~mm}$ de espessura (PEAD), a qual disporá de um sistema de drenos e brita na parte de baixo para detecção de eventuais vazamentos (que serão conduzidos aos poços de inspeção e monitoramento do aterro) 
- finalmente por cima do PEAD existirá uma camada de areia envolvendo as manilhas perfuradas para coleta do lixiviado, encaminhado para coleta e transporte para a ETE Barueri

A estrutura descrita se repetirá a cada 6 metros, altura de lodo em cada célula, até atingir o coroamento quando será selada por PEAD, por uma camada protetora de areia, por uma camada filtrante de brita e areia, por solo de boa qualidade para plantio, por terra e por um revestimento vegetal para recomposição visual da área (Sabesp, 1995).

A secção transversal esquemática na Figura 3 ilustra as camadas acima descritas. 


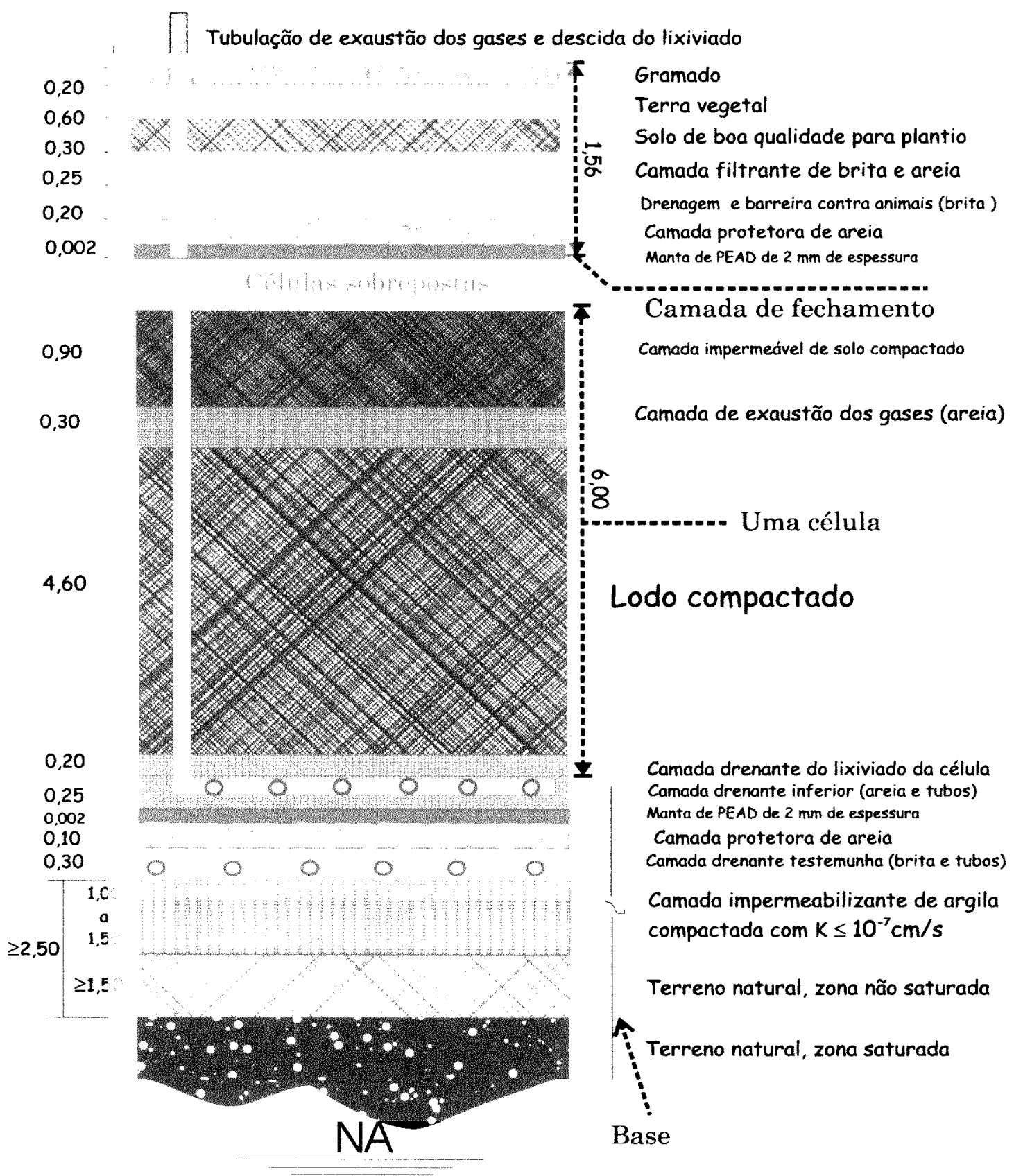

Dimensões em metros

Figura 3 Seção transversal típica do aterro exclusivo multinivel Classe 1 da Sabesp.

Fonte: $\quad$ Sabesp-Setembro/1995: EIA do Aterro Sanitário Exclusivo: Células de Disposição - Detalhes 


\subsection{Tipos de tortas de lodo de filtro-prensa na ETE Barueri}

Como já assinalado, as tortas de lodo da ETE Barueri na época da realização dos trabalhos desta tese eram condicionadas com $22 \%$ de cal e $8 \%$ de cloreto férrico. Ainda em 1998, no transcurso do presente trabalho, o pré-condicionamento antes da filtragem passou a ser feito com polímeros. Foi verificado por Kenji, em 1998, que o polímero em pó e o cloreto férrico, a $4,83 \mathrm{~kg} / \mathrm{t}$ e $6,3 \%$ respectivamente, resultaram em tortas $31 \% \mathrm{BS}$ e densidade de $1,13 \mathrm{~kg} / \mathrm{L}$. Kenji constatou ainda que o uso apenas do polímero em pó, trazia dificuldades para a liberação das tortas da lona do filtro. Os polímeros permitiram taxas iniciais de filtração mais altas e tempo de filtração em torno de 120 minutos, portanto ciclos operacionais mais curtos. Conforme o último relatório de desempenho operacional da empresa (Sabesp [b], 2002. p.34), devido ao acúmulo de resíduos na placa do filtro-prensa, em dezembro de 2001 foi reiniciada a aplicação de cloreto férrico na desidratação mecânica.

Observe-se que o condicionamento com cal e cloreto férrico continua sendo feito em algumas das cinco estações de grande porte que tratam esgotos sanitários na RMSP, bem como em diversas ETE's em todo Brasil, conservando a aplicabilidade de algumas conclusões do presente estudo.

Realmente, o relatório anual de desempenho operacional de julho de 2001 a junho de 2002 da Sabesp indica que para as $312 \mathrm{t} / \mathrm{d}$ de tortas produzidas nas depuradoras de Barueri, Suzano, ABC, Parque Novo Mundo e São Miguel, a concentração média de sólidos situou-se em torno de 33\%. Assinala que nas ETE's de ABC e Suzano o lodo é condicionado com cal e cloreto férrico antes dos filtros-prensa de placas, nas proporções cal / cloreto (em peso de ST do lodo) iguais a $23 \%$ e $7 \%$ para a ETE ABC e de $20 \%$ e $10 \%$ para a ETE Suzano, respectivamente. Também na ETE Parque Novo Mundo é utilizado cal e cloreto férrico no lodo flotado, nas proporções em peso de $38 \%$ e $7 \%$ para cal e cloreto, antes da desidratação por filtros-prensa diafragma. Na ETE Barueri o lodo digerido é condicionado com $6 \%$ de polímero e $3 \%$ de cloreto férrico, ambos em peso 
(ST) e na ETE São Miguel, com polímero e cloreto férrico, após o que passam pelo filtro-prensa diafragma e vão para a secagem térmica.

A mudança do pré-condicionamento de cal virgem para polimeros, deve dificultar a disposição das tortas no aterro.

Ludovico Spinosa and P. Aarne Vesilind em "Sludge into Biosolids: Processing, Disposal" (IWA, 2001) já alertam que "Polymer-treated sludges may require higher solids content to ensure bearing capacities".

Entretanto, esta troca traz vantagens operacionais já ressaltadas por Kenji, 1998. Uma das vantagens foi constatada pelo autor da presente tese e encontra-se ilustrada Tabela 2 , que compara dados de produção de tortas da ETE Barueri, do biênio 1993/1994 com os do biênio 1999/2000 (trazendo ainda dados do último relatório de desempenho operacional da empresa de julho de 2002).

Observa-se que em 1993/94, Barueri tratava $4,1 \mathrm{~m}^{3} / \mathrm{s}$ de esgotos (média de 18 meses) e produzia, em média, 5.898 toneladas de torta mensalmente. A concentração média de sólidos na torta era de $41 \% \pm 2 \%$. Após a mudança para polímeros no précondicionamento, no periodo 1999/2000, Barueri já tratava $5,4 \mathrm{~m} / \mathrm{s}$, mas continuava produzindo praticamente a mesma quantidade de tortas (5.963 t/mês), evidentemente com maior quantidade de água $(36 \% \pm 3 \%)$. Para um acréscimo de $32 \%$ na vazão tratada houve um aumento de apenas $1,1 \%$ na massa média de tortas produzidas mensalmente. Como se comprova, em base seca o resultado ainda é mais significativo: Produção em base seca anterior: $\frac{\left(\frac{5898}{30}\right) \times 0,41}{4,1}=19,66(\mathrm{ts} / \mathrm{dia}) /\left(\mathrm{m}^{3} / \mathrm{s}\right), \mathrm{com} \mathrm{cal}$ Produção em base seca atual: $\frac{\left(\frac{5963}{30}\right) \times 0,36}{5,4}=13,25(\mathrm{ts} / \mathrm{dia}) /\left(\mathrm{m}^{3} / \mathrm{s}\right)$, com polimero ou uma redução de $32,6 \% \mathrm{em}$ termos absolutos. 
Tabela 2: Produção comparativa de lodo na ETE Barueri conforme o condicionamento química antes da filtragem

\begin{tabular}{|c|c|c|c|c|c|c|c|c|c|c|c|}
\hline \multirow{2}{*}{\multicolumn{4}{|c|}{$\begin{array}{l}\text { Cal e Cloreto Férrico } \\
\text { (1) Periodo Abril/1993 a Set/1994 }\end{array}$}} & \multicolumn{8}{|c|}{ Polímeros e Cloreto Férrico } \\
\hline & & & & \multicolumn{4}{|c|}{ (2) Periodo Jan/1999 a Ago/2000 } & \multicolumn{4}{|c|}{ (3) Periodo jul/2001 a jun/2002 } \\
\hline Mes/ano & $\begin{array}{l}\text { Tortas } \\
\text { t/mês }\end{array}$ & $\begin{array}{c}\% \\
\text { solid }\end{array}$ & $\begin{array}{l}\mathrm{Q}_{\text {tratada }} \\
\mathrm{m}^{2} / \mathrm{s}\end{array}$ & Mes/ano & $\begin{array}{l}\text { Tortas } \\
\text { Umês }\end{array}$ & $\begin{array}{c}\% \\
\text { solid }\end{array}$ & $\begin{array}{c}\mathrm{Q}_{\text {tratada }} \\
\mathrm{m}^{3} / \mathrm{s}\end{array}$ & Mes/ano & $\begin{array}{l}\text { Tortas } \\
\text { U/mês }\end{array}$ & $\begin{array}{c}\% \\
\text { solid }\end{array}$ & $\begin{array}{c}\text { Qursada } \\
\mathrm{m}^{\prime} / \mathrm{s}\end{array}$ \\
\hline- & & & & $\operatorname{mar} / 99$ & 4.340 & 39 & 4,4 & - & - & - & - \\
\hline $\mathrm{abr} / 93$ & 5.285 & 43 & 4,02 & $\mathrm{abr} / 99$ & 5.610 & 36 & 3,7 & - & - & - & - \\
\hline $\mathrm{mai} / 93$ & 6.786 & 42 & 4,21 & $\mathrm{mai} / 99$ & 4.929 & 32 & 3,7 & - & - & - & - \\
\hline jun/93 & 6.708 & 41 & 3,68 & jun/99 & 6.000 & 33 & 3,7 & - & - & - & - \\
\hline $\mathrm{jul} / 93$ & 4.388 & 37 & 3,81 & jul/99 & 6.479 & 36 & 4,3 & $\mathrm{jul} / 01$ & 5.828 & n.d. & 6,46 \\
\hline ago/93 & 5.538 & 40 & 3,97 & ago/99 & 6.355 & 37 & 4,3 & ago/01 & 5.859 & n.d. & 6,49 \\
\hline set/93 & 6.123 & 43 & 4,00 & set/99 & 7.770 & 35 & 4,4 & $\mathrm{set} / 01$ & 5.640 & n.d. & 5,97 \\
\hline out $/ 93$ & 6.279 & 38 & 4,03 & out/99 & 5.115 & 36 & 4,5 & out/0l & 7.037 & n.d. & 5,76 \\
\hline nov/93 & 8.015 & 42 & 4,37 & nov/99 & 4.500 & 29 & 4,7 & nov/01 & 5.310 & n.d. & 6,58 \\
\hline $\mathrm{dez} / 93$ & 7.508 & 42 & 4,03 & $\operatorname{dez} / 99$ & 6.448 & 30 & 5,2 & $\mathrm{dez} / 01$ & 7.770 & n.d. & 6,99 \\
\hline $\mathrm{jan} / 94$ & 6.299 & 45 & 4,52 & $\mathrm{jan} / 00$ & 5.084 & 40 & 8,6 & $\mathrm{jan} / 02$ & 9.548 & n.d. & 7,04 \\
\hline fev/94 & 5.831 & 42 & 4,39 & fev/00 & 6.552 & 38 & 8,8 & fev/02 & 5.301 & n.d. & 6,43 \\
\hline $\mathrm{mar} / 94$ & 7.722 & 42 & 4,78 & $\mathrm{mar} / 00$ & 6.324 & 40 & 7,6 & $\mathrm{mar} / 02$ & 6.720 & n.d. & 6,65 \\
\hline $\mathrm{abr} / 94$ & 6.201 & 41 & 4,21 & $\mathrm{abr} / 00$ & 7.710 & 41 & 6,4 & $\mathrm{abr} / 02$ & 7.471 & n.d. & 6,42 \\
\hline $\mathrm{mai} / 94$ & 6.377 & 38 & 4,08 & $\mathrm{mai} / 00$ & 6.231 & 32 & 6,5 & mai/02 & 6.750 & n.d. & 6,57 \\
\hline jun/94 & 6.318 & 40 & 4,07 & jun/00 & 6.780 & 35 & 5,5 & jun/02 & 9.083 & n.d. & 6,31 \\
\hline jul/94 & 5.577 & 33 & 4,00 & jul/00 & 5.394 & - & 4,3 & - & - & - & - \\
\hline $\mathrm{ago} / 94$ & 156 & - & 4,03 & ago/00 & 5.704 & - & 5,9 & - & - & - & - \\
\hline $\mathrm{set} / 94$ & 5.051 & 34 & 4,11 & - & - & - & - & - & - & - & - \\
\hline Total: & 106.162 & & & Total: & 107.325 & & & Total: & 82.317 & & \\
\hline Média: & 5.898 & 41 & 4,1 & Média: & 5.963 & 36 & 5,4 & Múdia: & 6.860 & & 6,5 \\
\hline$\sigma=$ & 1.703 & 2 & 0,3 & $\sigma=$ & 971 & 3 & 1,6 & $\sigma=$ & 1.408 & & 0,4 \\
\hline $\begin{array}{l}\text { Convençào: } \\
\text { Fontes: }\end{array}$ & $\begin{array}{l}\text { ax pessoa } \\
\text { intese de }\end{array}$ & ETE & ima pr & $\begin{array}{l}0 \text { mesal } \\
\text { APDE - } \\
\text { O/2000 }\end{array}$ & $\begin{array}{l}\text { nodo } \\
\text { esp }\end{array}$ & & & 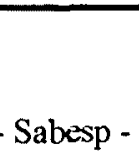 & 2002 & & \\
\hline
\end{tabular}




\subsection{Perspectiva atual de uso agrícola dos lodos da ETE Barueri}

Com relação ao uso agricola constatou-se recentemente que:

[...] em relação à densidade de organismos patogênicos, análises laboratoriais mais completas realizadas em 1999, mesmo sem adição de cal no processo de condicionamento, indicaram que o lodo da ETE Barueri é Classe A, segundo a legislação norte-americana, mas não o é de acordo com a regulamentação CETESB. (Sabesp, 2002, 5.15, Conclusões).

Conforme Sabesp, 2002, 5.13.3, as duas análises realizadas em novembro de 1999 indicaram enterovirus e ovos de helmintos ausentes, enquanto a concentração de Salmonellas sp. esteve abaixo do limite para a classe A pela 40 CFR Part 503, tendo sido igual a 2,92 NMP/4 g ST (o limite é $3 \mathrm{NMP} / 4 \mathrm{~g} \mathrm{ST}$ ). Entretanto, o NMP de coliformes superou os 1000 por grama de sólidos totais exigidos pela norma $\mathrm{P} 4230$ para lodo classe A.

Contrariamente à norma norte-americana, que exige o atendimento ou ao limite para coliformes ou ao limite para Salmonellas $s p$, a norma da Cetesb exige que ambos limites sejam atendidos para que o lodo seja considerado classe A. (Santos, 2001)

Não obstante, mesmo a P 4230 permitiria que o lodo fosse classificado como classe B e portanto adequado para uso agricola com restrições de tipos de cultura, acesso restrito ao local da plantação por animais e pela população, dentre outras precauções (P-4.230, Cetesb, 1999). 


\section{MATERIAIS E MÉTODOS}

\subsection{Materiais}

\subsubsection{Filtros prensa da estação:}

A ETE Barueri possui três filtros prensa de placa tipo volume fixo que trabalham continuamente desidratando o lodo digerido anaerobiamente. O précondicionamento das tortas durante os trabalhos desta tese era feito com cal e cloreto férrico, posteriormente apenas com polímeros e atualmente se faz com polímeros e cloreto férrico. As duas primeiras situações foram examinadas na elaboração do presente estudo.

Cada descarga de um filtro de 150 placas de $2 \mathrm{~m} \times 2 \mathrm{~m}$ leva 20 minutos e produz de 18 a 20 toneladas de torta. A produção diária oscila em torno de 100 toneladas, com três ou mais ciclos de prensagem por filtro. A Figura 4 mostra como o operador solta a torta prensada com uma espátula de madeira. A torta cai por um vão do piso até um cabo de aço acima da esteira rolante no térreo que transporta seus fragmentos para o pátio.

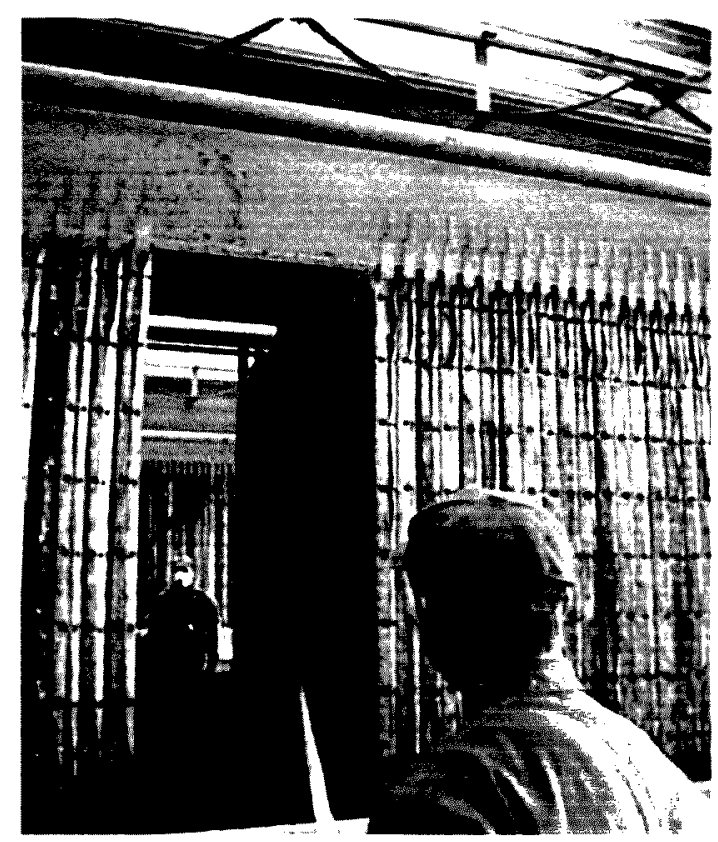

Figura 4 Descarga do lodo de um dos filtros prensa da ETE Barueri 
Devido ao processo de geração das tortas (adensamento do lodo primário e secundário respectivamente por gravidade e flotação, condicionamento da mistura de lodos com cal (ou polímero) e cloreto férrico, abastecimento dos filtros-prensa a partir de tanques diários) cada descarga dos filtros é composta de material com grande homogeneidade química e bacteriológica.

\title{
4.1.2 Recebimento da cal virgem para as pistas experimentais
}

Uma quantidade considerável de cal virgem foi trazida para o pátio da ETE tendo-se em vista a construção das pistas experimentais. Um retrospecto do problema revelou que os estudos realizados no plano diretor de lodos (Sabesp, 1996, p.64), indicavam com bastante ênfase que:

\begin{abstract}
"para serem compactados os lodos deverão ser submetidos a alguma melhoria em termos de trabalho geotécnico. No teor de MS original, de $40 \%$, não há qualquer possibilidade de lançamento e compactação posterior. Foram desenvolvidos ensaios geotécnicos visando equacionar este ponto, tendo sido assumido o parâmetro de coesão igual ou maior que $0,4 \mathrm{~kg} / \mathrm{cm}^{2}$ para propiciar o trabalho de compactação posterior." (Sabesp, 1996, p.64)
\end{abstract}

Mais adiante os mesmos estudos tornaram a frisar (Sabesp, 1996, p.64,65)

\begin{abstract}
"Prevê-se a realização, no âmbito do planejamento do aterro exclusivo, de ensaios em pista experimental onde misturas de lodo-cal de diversos teores deverão ser submetidas ao trabalho de equipamentos de terraplenagem de diferentes capacidades, visando estabelecer, em escala de campo, os parâmetros estabelecidos em escala de laboratório, para uma aproximação maior aos valores da realidade operacional" (Sabesp, 1996, p.64,65)
\end{abstract}


E com fundamento no exposto, ainda durante os trabalhos do plano diretor de lodos foram feitos estudos de bancada e mesmo de campo, na própria ETE Barueri.

Nesta época foi utilizada uma simples betoneira para misturar a torta de lodo a $40 \%$ de sólidos com a cal virgem. A mistura foi feita com bastante dificuldade devido a aderência da massa nas lâminas internas do tambor e à baixa trabalhabilidade da mistura. Como se mostra na seqüência, para os trabalhos aqui documentados o equipamento usado foi específico e bastante apropriado para o objetivo a alcançar.

Os testes feitos na época do plano diretor, com as limitações de escala e equipamento acima mencionadas, permitiram as conclusões que constam na Tabela 3, onde pode ser observado, na segunda linha, as indicações que motivaram parte dos experimentos desenvolvidos nesta tese, qual seja a mistura de $17,5 \%$ de cal em peso com as tortas de lodo em pistas construídas dentro do pátio da ETE.

Tabela 3: Experiências anteriores de mistura de tortas de lodo com materiais diversos e rendimento obtidos

\begin{tabular}{|c|c|c|c|c|c|}
\hline $\begin{array}{l}\text { Teor de MS dos } \\
\text { lodos }\end{array}$ & $\begin{array}{l}\text { Material de } \\
\text { mistura }\end{array}$ & $\begin{array}{c}\text { Melhor } \\
\text { proporção em } \\
\text { peso }\end{array}$ & Coesão final & Densidade & $\begin{array}{c}\text { Rendimento no } \\
\text { aterro }\end{array}$ \\
\hline$\%$ & & & $\mathrm{~kg} / \mathrm{cm} 2$ & $\mathrm{t} / \mathrm{m} 3$ & ts lodo/m3 \\
\hline 40 & solos locais & $1: 2,00$ & 0,5 & 1,72 & 0,23 \\
\hline 40 & cal vingem & $1: 0,175$ & 0,72 & 1,27 & 0,434 \\
\hline 40 & lodo a $90 \%$ & $1: 0,7$ & 0,4 & 1,23 & 0,752 \\
\hline 40 & cal e lodo a $90 \%$ & $1: 0,125: 0,79\left(^{*}\right)$ & $\approx 0,7$ & 1,23 & 0,717 \\
\hline 32 & solos locais & $1: 2,50\left(^{*}\right)$ & 0,5 & 1,77 & 0,662 \\
\hline 32 & cal virgem & $1: 0,25\left(^{*}\right)$ & 0,7 & 1,35 & 0,346 \\
\hline
\end{tabular}

Nota: grifo em cal virgem é do presente documento.

Fonte: Sabesp, 1996 - Quadro 4.2

Para possibilitar a construção das pistas experimentais foram recebidas $22 \mathrm{t}$ de cal virgem em 22 big-bags, descarregados e abrigados no pátio da estação como se observa nas Figuras 5, 6 e 7. 


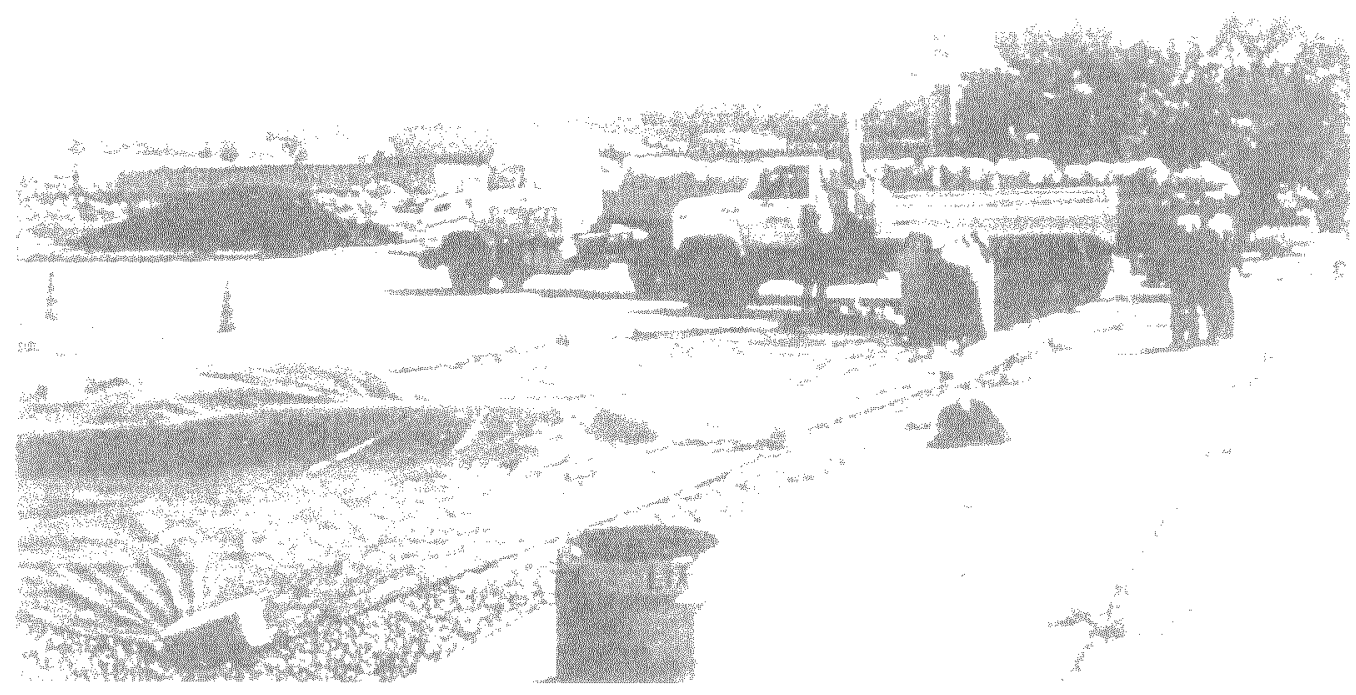

Figura 5 Caminhões de cal virgem ao fundo e pista protegida com lonas plásticas em primeiro plano

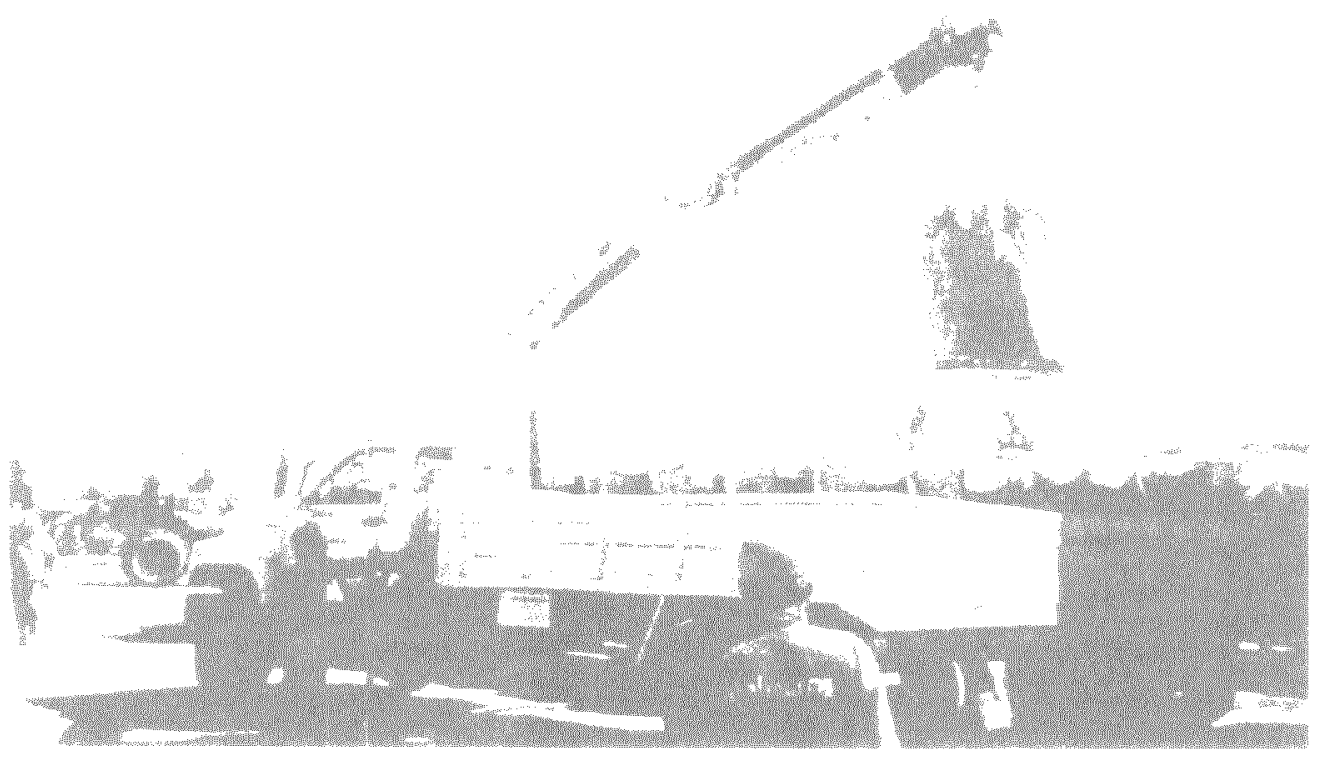

Figura 6 Descarga do 'big-bag' de cal do caminhão 


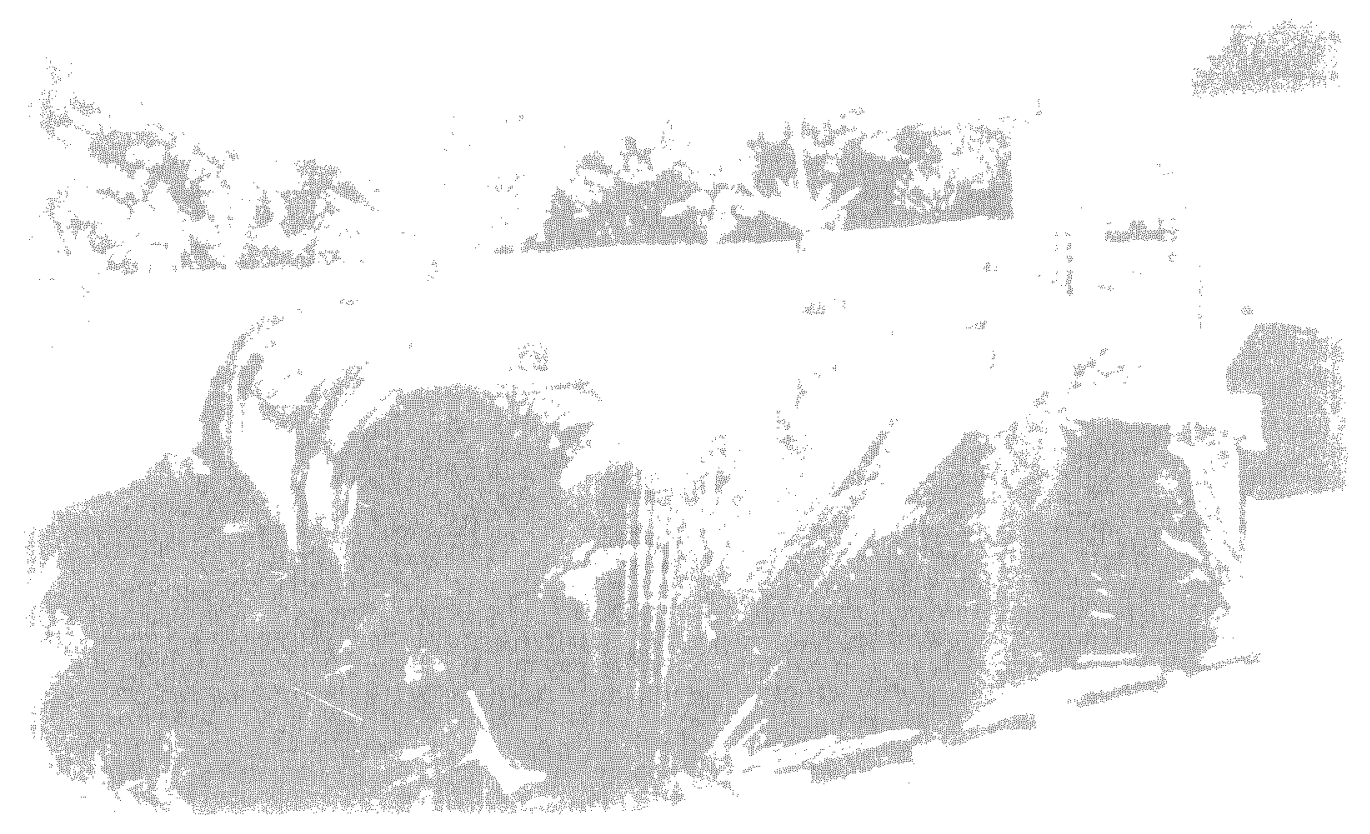

Figura $7 \quad$ Big-bags de cal virgem, apoiados em pallets, e cobertos por lona plástica.

\subsubsection{Equipamento de mistura de aditivos na torta de lodo para construção da pista}

Para acréscimo e mistura dos aditivos minerais (cal em pós-adição à torta desidratada e Absorsol) foi utilizado o equipamento da empresa contratada pela Sabesp, a Alphageos Geologia, Geotecnia e Comércio Ltda. As fotos mostram o misturador-dosador que foi utilizado, um equipamento verdadeiramente apropriado para trabalhar com produtos com alta viscosidade e plasticidade, como sabidamente é o caso de tortas de lodo com concentrações em torno de $50 \%$ de sólidos (considerando-se a perda adicional de umidade pela manipulação no pátio).

As fotos seguintes mostram a carga e descarga nos equipamento misturador empregado. 


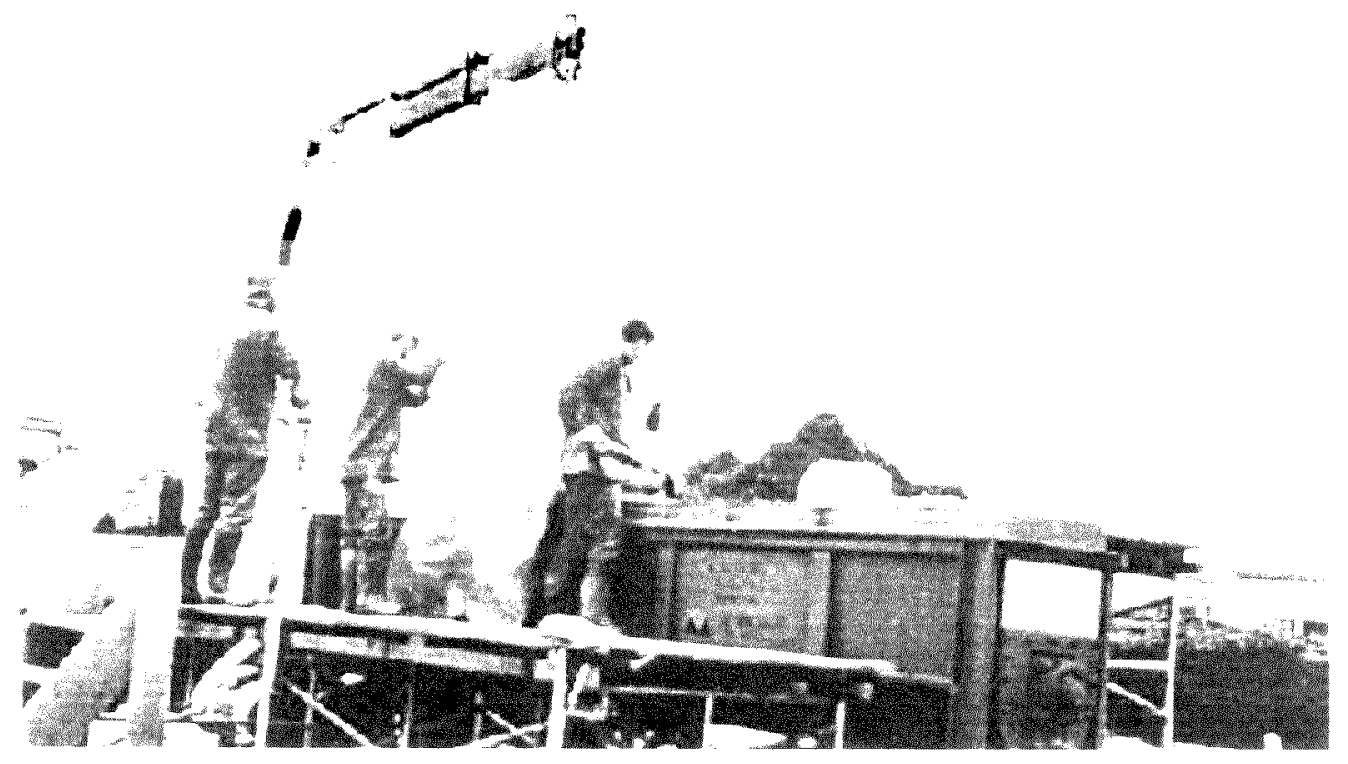

Figura 8 Equipamento para mistura de aditivos na torta de lodo

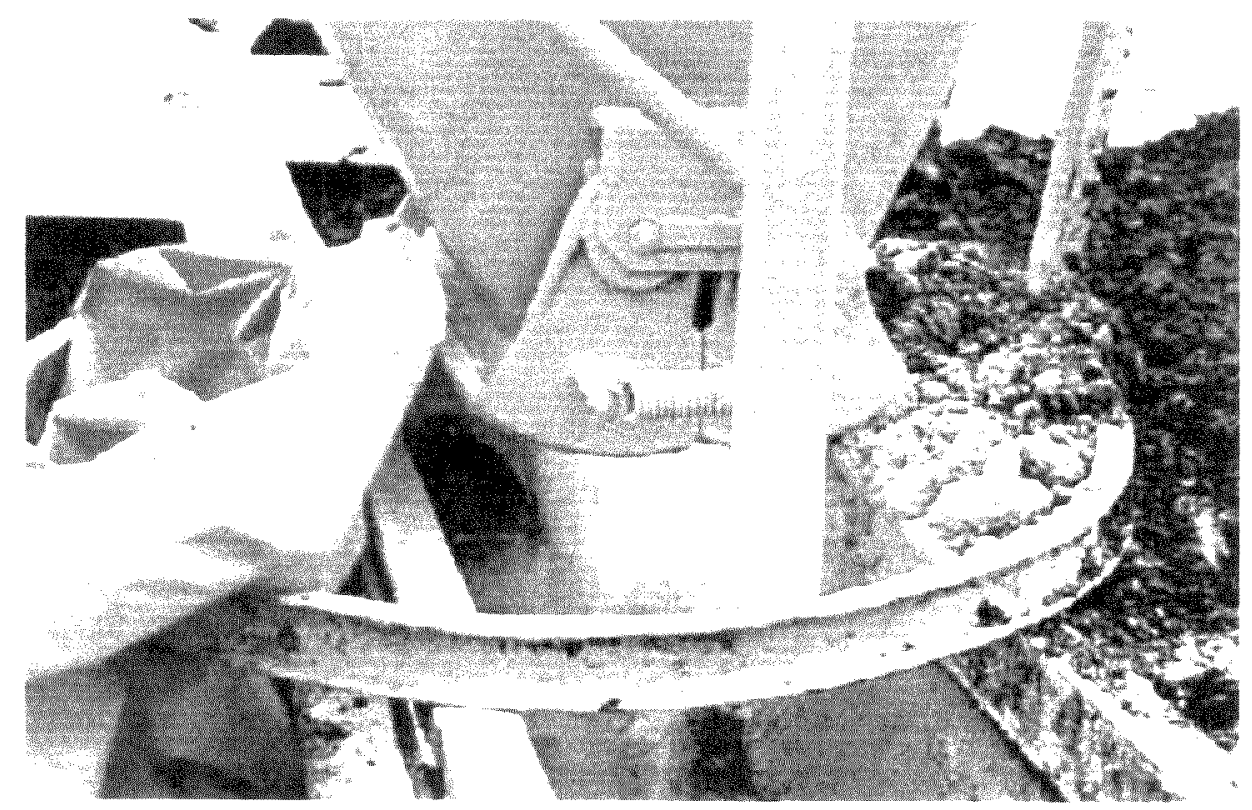

Figura 9 Detalhe do alimentador de rosca 


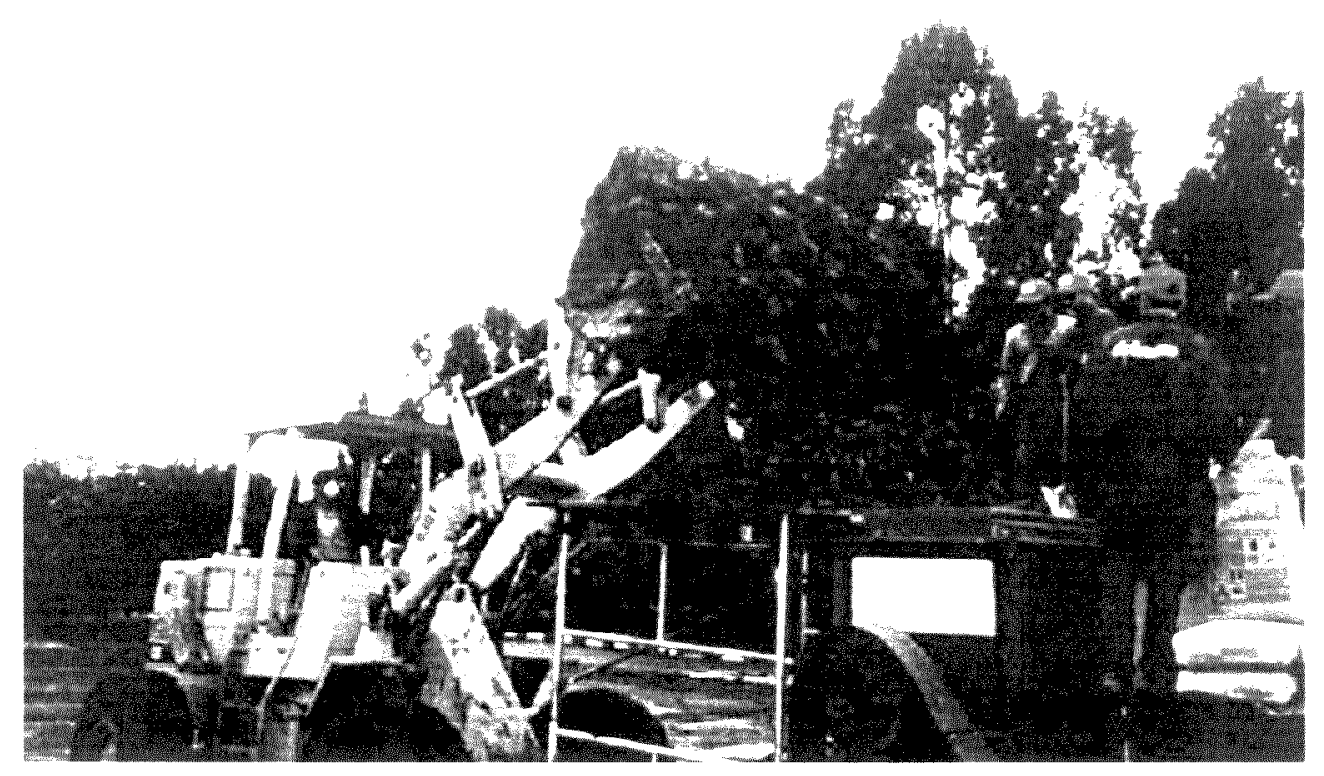

Figura 10 Descarga da torta do filtro na plataforma do misturador de aditivos, vendo o saco de Absorsol a direita da foto

\subsubsection{Ensaio do Índice Suporte Califórnia (ISC)}

A medida mais utilizada em todo o mundo para o dimensionamento de pavimentos é o CBR ("Califórnia Bearing Ratio"), ou ISC (Índice de Suporte Califórnia). O CBR mede a resistência de um dado material (solo ou brita) à carga. Ele reflete a ação do tráfego sobre a superficie ou base em uma situação extrema, a imersão (saturação por água).

É usado na seleção de material e controle de sub-leitos. Pode ser realizado em todos os tipos de solo e é baseado na resistência de penetração do solo testado comparado com a de um pedregulho teórico.

Compacta-se a amostra de solo, num cilindro de $15 \mathrm{~cm}$ de diâmetro de $17 \mathrm{~cm}$ de altura, na umidade ótima, até atingir a massa específica aparente seca que se deseja. Após a compactação inunda-se o corpo de prova, sob pressão ou não, durante 4 dias, a fim de se 
procurar atingir a sua saturação. Sob a amostra em saturação é colocado um peso de $5 \mathrm{~kg}$ para simular a resistência que o peso do pavimento impõe a sua expansão. Aproveita-se a saturação para se medir por meio de um deflectômetro a expansão que a amostra sofre ao saturar-se. Assim preparado o corpo de prova, dá-se inicio ao ensaio. Por meio de um macaco hidráulico reagindo contra uma armação metálica, faz-se pressão sobre o corpo de prova com um punção cilíndrico de $5 \mathrm{~cm}$ de diâmetro. Um manômetro dá a pressão aplicada e um deflectômetro mede as deformações com as quais se traça o gráfico pressão x deformação (Pattrol, 2002)

Define-se o Índice de Suporte California (CBR) como sendo:

$C B R=\frac{P}{70} \times 100$

onde P é a pressão de punção para uma deformação de $2.5 \mathrm{~mm} \mathrm{em} \mathrm{kgf} / \mathrm{cm}^{2}$.

$\mathrm{O}$ valor $70 \mathrm{kgf} / \mathrm{cm}^{2}$ corresponde á máxima resistência do ISC que se espera de um solo bom, onde ele será estabilizado e terá características ótimas para uma base de pavimento rodoviário. (Pattrol, 2002)

\subsubsection{Uso do ISC na avaliação das pistas experimentais}

O ensaio ISC consta das especificações do método do DNER-ME 049/94. A especificação de serviço da prefeitura municipal de Curitiba, por exemplo, estipula que turfas e argilas não são admissiveis para compactação em aterros, bem como fixa os limites aceitáveis para os resultados do ISC, que para o corpo do aterro não deverá ser inferior a 2\%. A mesma especificação de serviço (PMC-ES 015/99) menciona como equipamentos de terraplenagem para construção dos aterros rodoviários os caminhões pipa, os caminhões basculantes, as motoniveladoras com escarificadores, os rolos estáticos e/ou vibratórios, lisos ou pé-de-carneiro, as grades de disco, a pá carregadeira (ou pá mecânica) e a retroescavadeira. Evidentemente ISC deve não só permitir a 
aprovação de uma compactação que suporte o trafego desses equipamentos como, principalmente, suportar a base, a pista de rolamento e o próprio tráfego da futura rodovia.

A interpretação dos resultados do ISC para os aterros exclusivos de lodo deve levar em conta que o único tráfego que eles precisam suportar são os necessários para sua construção, uma vez que o terreno recomposto não se prestará de forma alguma ao trafego rodoviário habitual. Esta distinção é importante quando se lembra que nem ao menos turfas ou argilas são admissiveis na construção de aterros rodoviários, como anteriormente afirmado. Pode também ser reforçada pela definição de aterro rodoviário, como consta na norma DNER-ES 282/97: "Aterros: segmentos de rodovia cuja implantação requer depósito de materiais provenientes de cortes, e/ou de empréstimos no interior dos limites das seções de projeto ("off-sets") que definem o corpo estradal."

Pontos de semelhança entre as duas obras podem ser vistos nos métodos construtivos de ambas, como se depreende das descrições a seguir.

Das especificações de serviço para aterros rodoviários (PMC-ES 015/99):

b) O lançamento do material na compactação dos aterros deve ser feito em camadas sucessivas, em toda a largura da seção transversal. A espessura da camada compactada não deverá ultrapassar $0,30 \mathrm{~m}$ no corpo do aterro. Para a camada final, a espessura não deverá ultrapassar 0,20m;

c) Para o corpo de aterro será exigido um Grau de Compactação de $95 \%$, com umidade ótima de $\pm 3 \%$. Para a camada final, o Grau de Compactação será de $100 \%$;

d) As áreas de acesso próximas aos encontros de pontes, o enchimento de covas das fundações e as trincheiras de bueiros, bem como todas as áreas de dificil acesso ao equipamento usual de compactação, serão 
compactadas mediante a utilização de equipamentos adequados, como soquetes manuais, sapos, placas vibratórias e rolos de pequeno porte, na umidade ótima descrita para o corpo dos aterros;

e) Para a determinação da massa específica aparente de cada camada do material compactado, utilizar o método de ensaio "in situ" (Método DNER ME-092/94);

f) A compactação deverá evoluir longitudinalmente, iniciando no bordo mais baixo e progredindo no sentido do bordo mais alto da seção transversal ou meia seção transversal, exigindo-se que em cada passada do equipamento seja recoberta, no mínimo, a metade da largura da faixa anteriormente comprimida. (PMC-ES 015/99, p.2)

Este método construtivo apresenta semelhanças com a concepção do aterro multinivel para lodos no que diz respeito à construção dos diques intermediários que, quando superpostos, constituirão os limites das diversas células de deposição do lodo (veja seções transversais, típica e das camadas componentes do aterro, nas Figuras 1 e 3) e também, evidentemente, com a do maciço da barragem de terra que conterá toda obra a jusante. Apenas com a finalidade de identificar as semelhanças e diferenças entre as naturezas das duas obras, reproduzem-se as descrições constantes do item 4.10.1, "Concepção Geral, Barragem e Diques", e 4.10.12.4, "Análises e Estabilidade" (Sabesp,1995):

Do item 4.10.1, Concepção Geral, Barragem e Diques:

....No ponto baixo da bacia erguer-se-á uma barragem de terra que, unindo as encostas da bacia natural, conformará a bacia de disposição.

O volume assim definido será subdividido em células, formadas por diques de terra compactada de seis metros de altura, nas quais serão dispostos os residuos 
Cada célula que for sendo preenchida, receberá um selo de solo compactado

Após o preenchimento de todas células de uma mesma fase ou nivel, a barragem será alteada de seis metros, criando um novo volume, que será ocupado por novas células, sobrepostas às da fase anterior, e assim sucessivamente.

...A barragem terá a função estrutural de fechamento da bacia dando estabilidade a toda a massa de lodos. Terá taludes $\mathrm{I}(\mathrm{V})$ : 1,5(H), a montante e 1: 2,5 , a jusante.

Embora os lodos venham a ser compactados, como se desconhece o seu comportamento quanto a adensamento a longo prazo, os diques serão construídos sempre sobre os diques da fase anterior ou sobre terreno natural e sobre eles circularão os caminhões e máquinas da operação.

Do item 4.10.12.4, Análises e Estabilidade (Sabesp,1995):

a) Maciço da barragem

A estabilidade do talude da barragem foi verificada apenas para sua face de jusante, em vista de o talude de montante apresentar sempre alturas de 6,0 m, conforme processo executivo do Aterro Exclusivo.

Para esta condição foram considerados dois tipos de seções transversais de aterro da barragem, ambos com fundações sobre solo bastante resistente, isto $\dot{e}$, admitindo removida toda camada de 
sedimento aluvionar, e remoção com recompactação do horizonte de solo de alteração de rocha que apresenta baixa consistÊncia. As seções foram analisadas com taludes de $1: 2.5(\mathrm{~V}: \mathrm{H})$ e $1: 3(\mathrm{~V}: \mathrm{H})$ e, nestas condições, foram estabelecidos, para efeito de análise de estabilidade, os seguintes parâmetros médios de solo:

$$
\begin{aligned}
& C_{1}=5,0 \mathrm{tf} / \mathrm{m}^{2} \\
& \varnothing=25^{\circ} \mathrm{C} \\
& \gamma=1,9 \mathrm{tf} / \mathrm{m}^{3}
\end{aligned}
$$

(Observação: a recomendação mínima para aceitação da resistência ao tráfego sobre o aterro exclusivo foi de $0,4 \mathrm{kgf} / \mathrm{cm}^{2}$. Nota-se que $\mathrm{C}=5,0 \mathrm{tf} / \mathrm{m}^{2}=0,5 \mathrm{kgf} / \mathrm{cm}^{2}$. Notar também os coeficientes de segurança implícitos na hipótese - indicados logo abaixo)

Os valores dos coeficientes de segurança, resultaram em:

$$
\begin{aligned}
& 1: 2,5-F S=1,8 \\
& 1: 3,0-F S=1,95
\end{aligned}
$$

Em vista destes resultados, optou-se pelo primeiro caso.

b) Diques

A estabilidade dos diques foi estudada em sua situação mais crítica que é aquela apoiada parcialmente na mistura lodo-cal da célula do nível inferior.

Nestas condições foram adotados para o dique os mesmos valores utilizados para a barragem. No caso do lodo foram analisados não 
somente os resultados recentes realizados com a mistura lodo-cal, mas estimado também a aquisição de algum atrito com esse tratamento.

Foram adotados os seguintes parâmetros para a mistura lodo-cal:

$\mathrm{C}=5,0 \mathrm{tf} / \mathrm{m}^{2}$

$\varnothing=10^{\circ} \mathrm{C}$

$\gamma=1,2 \mathrm{tf} / \mathrm{m}^{3}$

c) Taludes Críticos dos Cortes

(como é um item que analisa a caracterização geológica da área deixa de ser transcrito pois fica prejudicado pela mudança de local - da margem da rodovia Castelo Branco para margem da rodovia Anhanguera).

d) Recalques

Os recalques decorrentes do processo de adensamento da mistura com lodo somente ocorrerão quando este pacote, submetido a percolação de águas pluviais precipitadas durante o preenchimento da célula, sofrer carregamento por meio de sua própria carga ou pela superposição de niveis superiores.

Quando se completar o preenchimento de uma célula e antes da colocação do nível imediatamente superior estará se processando adensamento nas partes inferiores; inicialmente haverá um descarregamento, em termos de pressões efetivas, da camada inferior. Nestas condições os recalques serão muito pequenos, podendo ser insignificantes para efeito de cálculo. 
Entretanto com a disposição de células superiores, o carregamento fará acelerar os recalques do lodo da célula abaixo. Para efeito da estimativa dos recalques esperados com esses carregamentos sucessivos, está previsto realizar ensaios de adensamento edométrico em amostras de misturas compactadas nas condições naturais e com saturação.

As células terão dimensões básicas, no fundo, de $50 \mathrm{~m} \times 100 \mathrm{~m}$. As paredes laterais terão inclinação de $1,0(\mathrm{~V}): 1,5(\mathrm{H})$, ou seja, de 33 graus.

$\mathrm{Na}$ borda superior as células terão dimensões de $68 \mathrm{~m} \times 118 \mathrm{~m}$.. Estas dimensões expressam as células regulares. As células localizadas nas bordas de cada nivel deverão conformar-se às irregularidades da superficie do terreno natural; por isso terão dimensões variadas. As células regulares terão uma capacidade útil unitária para disposição de rejeitos de $28.490 \mathrm{~m}^{3}$

...Dos $6 \mathrm{~m}$ de altura de cada célula, 4,6 m serão ocupados pelo lodo, que será lançado compactado; ...os $0,9 \mathrm{~m}$ superiores serão ocupados pelo selo de solo, sob o qual haverá uma camada de $0,3 \mathrm{~m}$ de areia na qual serão recolhidos os gases. Os $0,2 \mathrm{~m}$ inferiores da célula serão ocupados por uma camada de areia através da qual escoará o lixiviado. (Sabesp, 1995, pl10-111)

Os equipamentos empregados para a realização do ISC, conforme a norma do DNER 049/94 foram os que constam na relação seguinte e em parte aparecem nas fotos das Figuras 40 a 44, mais adiante: 
- Balança tipo Roberval, com capacidade de $20 \mathrm{~kg}$, com jogo de pesos, modelo 620

- Balde galvanizado, graduado, com capacidade de 20 litros

- Disco espaçador de diâmetro 2,5"

- Extensômetro com curso de $10 \mathrm{~mm}$ e sensibilidade de $0,01 \mathrm{~mm}$

- Extrator de amostra manual com adaptação para cilindro ISC, Proctor e Marshall

- Molde cilíndrico ISC, com colar e base

- Papel filtro com diâmetro de $15 \mathrm{~cm}$

- Peso anelar de $5 \mathrm{~kg}$

- Prato perfurado com haste ajustável

- Prensa ISC de funcionamento elétrico/manual, completa, com conjunto de dinamômetro $110 / 220 \mathrm{~V}$

- Soquete compactador para ISC de $10 \mathrm{lb}$ com protetor de mão modelo DER/MG

- Tripé com porta-extensômetro de ferro fundido.

\subsubsection{Ensaios de compressão simples e outros ensaios}

O ensaio de compressão simples consiste em submeter-se um corpo de prova cilindrico, cuja altura seja no mínimo o dobro do diâmetro, a uma carga crescente que provoca tensões axiais de compressão causadoras de deformações no corpo de prova. Estas deformações são medidas marcando-se graficamente as curvas de pressão deformação até a ruptura. Em solos arenosos compactos ou nas argilas friáveis a ruptura se dá depois de uma deformação especifica pequena e as pressões necessárias para continuar deformando o material são menores do que as de ruptura. Nas areias fofas ou argilas moles as pressões requeridas para a deformação do corpo de prova aumentam continuamente até a ruptura, prosseguindo constantes daí por diante para qualquer deformação.(Globo, 1957; Tsutiya et al, 2001) 
Uma estimativa da coesão ou resistência interna do solo pode ser feita pelo teste da palheta (Vane Test), determinando-se a tensão de cisalhamento máxima do solo ensaiado. $O$ ensaio de compressão simples pode ser considerado como capaz de dar uma indicação qualitativa da coesão dos solos (Tsutiya et al, 2001).

Outros ensaios e cálculos a partir de ensaios podem ajudar a prever as deformações das obras de terra e seu comportamento mecânico, como o ensaio de compressão triaxial, e o cálculo do coeficiente de Poisson, estimado a partir do ensaio de compressão simples (Globo, 1957). Em estudos geotécnicos anteriores com o lodo da ETE Barueri, sem a consideração do Absorsol, foram utilizados como indicadores da futura resistência de suporte do aterro exclusivo ao tráfego, o ISC e o ensaio de compressão simples. Concluiu-se que o lodo pré-condicionado com polímeros tende a ter sua capacidade de suporte diminuída com o tempo, tal não tendo sido observado quando a cal foi empregada no précondicionamento da filtragem. (Tsutiya et al, 2001) 


\subsection{Metodologia}

\subsubsection{Coleta de amostras para tortas précondicionadas com cal}

O ANEXO B traz um diagrama com um desenho esquemático que ilustra as diversas coletas de amostras e os destinos das partidas de lodo amostradas durante os trabalhos. Para as amostras précondicionadas com cal, foi ajustada a seguinte metodologia com a equipe de operação da ETE para a coleta:

1. As amostras seriam retiradas de cada descarga do filtro-prensa.

2. Para cada cinco descargas do filtro-prensa (ou 100t), seria feita uma pilha segregada do restante da produção, formando-se assim quatro pilhas designadas como A, B, C e D, cada qual com 100 t, para investigação quanto ao seu possivel uso agrícola. Seriam também formadas as pilhas E e F para construção das pistas experimentais, as quais seriam analisadas antes e depois de aditivos em diversas proporções, como será detalhado mais adiante. Toda metodologia aqui descrita em detalhes para as pilhas A a D seria praticada para formação das pilhas $\mathrm{E}$ e F.

3. De cada uma das pilhas de 100t seria retirada uma amostra .

4. As quatro amostras das quatro pilhas seriam misturadas para formar uma amostra única designada pela letra $R$, 'Representativa' das $400 t$

Como resultado da amostragem foram portanto obtidas cinco amostras: R, A, B, C e D, inicialmente.

A amostra $\mathrm{R}$ foi enviada ao laboratório para exames fisico-químicos e microbiológicos referentes respectivamente às normas: 
- NBR 10.004, da Associação Brasileira de Normas Técnicas - ABNT, para classificação dos resíduos sólidos quanto aos seus riscos potenciais ao meio ambiente e a saúde pública e,

- 40 CFR 503 Part 503, da agência de proteção ambiental dos Estados Unidos (Usepa), tendo-se em vista a aplicação ou disposição do lodo de esgotos no solo. (A Norma 40 CFR part 503 - significa Code of Federal Regulations $n^{\circ} 40$, part 503 - "Standards for the Use and Disposal of Sewage Sludge").

$\mathrm{Na}$ época das análises, anterior a dezembro de 1999, a Cetesb ainda não havia publicado sua norma P 4230, embora já se soubesse que ela se constituiria numa adaptação da norma da USEPA. Diferenças significativas entre ambas são comentadas neste trabalho no que se refere às classificações $\mathrm{A}$ ou $\mathrm{B}$ do biossólido produzido em Barueri. Quanto às análises fisico-químicas, inexiste distinção significativa entre ambas normas.

Nas amostras retiradas de cada descarga dos filtros-prensa (para formação das pilhas A, B, C e D) foram também retiradas uma amostra de cada, pesando $200 \mathrm{~g}$, para fins de determinação de sua massa seca no laboratório.

Quanto à análise da amostra $\mathrm{R}$, a metodologia seguida foi a de realizar um quarteamento com $30 \mathrm{~kg}$ de lodo de cada uma de suas pilhas formadoras, A, B C e D.

- De cada uma das quatro pilhas de $100 \mathrm{t}$ foi retirado lodo para encher quatro recipientes com $30 \mathrm{~kg}$ de torta cada. Estas amostras de $30 \mathrm{~kg}$ foram formadas a partir da própria descarga do filtro, coletando-se 500/700 gramas a cada 2 minutos até formar $6 \mathrm{~kg}$ de amostra por descarga. As amostras de 5 descargas formaram então os $30 \mathrm{~kg}$ de cada recipiente, cada parcela desse peso extraída portanto das mesmas tortas formadoras das pilhas A, B, C e D. 
- Dos quatro recipientes de $30 \mathrm{~kg}$, representativos das pilhas $\mathrm{A}, \mathrm{B} \mathrm{C} \mathrm{e} \mathrm{D,} \mathrm{foram}$ retiradas duas parcelas de lodo, uma para o laboratório e a outra para mistura com a homóloga das outras pilhas, representando-se após a mistura, da forma mais fiel possivel, a amostra $\mathrm{R}$ das $400 \mathrm{t}$.

Desta maneira foram formadas as cinco amostras seguintes:

- Amostra A - representativa da pilha A.

- Amostra B - representativa da pilha B.

- Amostra C - representativa da pilha C.

- Amostra D - representativa da pilha D.

- Amostra R - representativa da média das quatro pilhas ou das $400 t$ de torta de lodo.

A Figura 11 mostra o aspecto das tortas de lodo pré-condicionadas com cal, no momento em que eram descarregadas no pátio a partir da esteira rolante situada no piso térreo do edificio de filtração. 


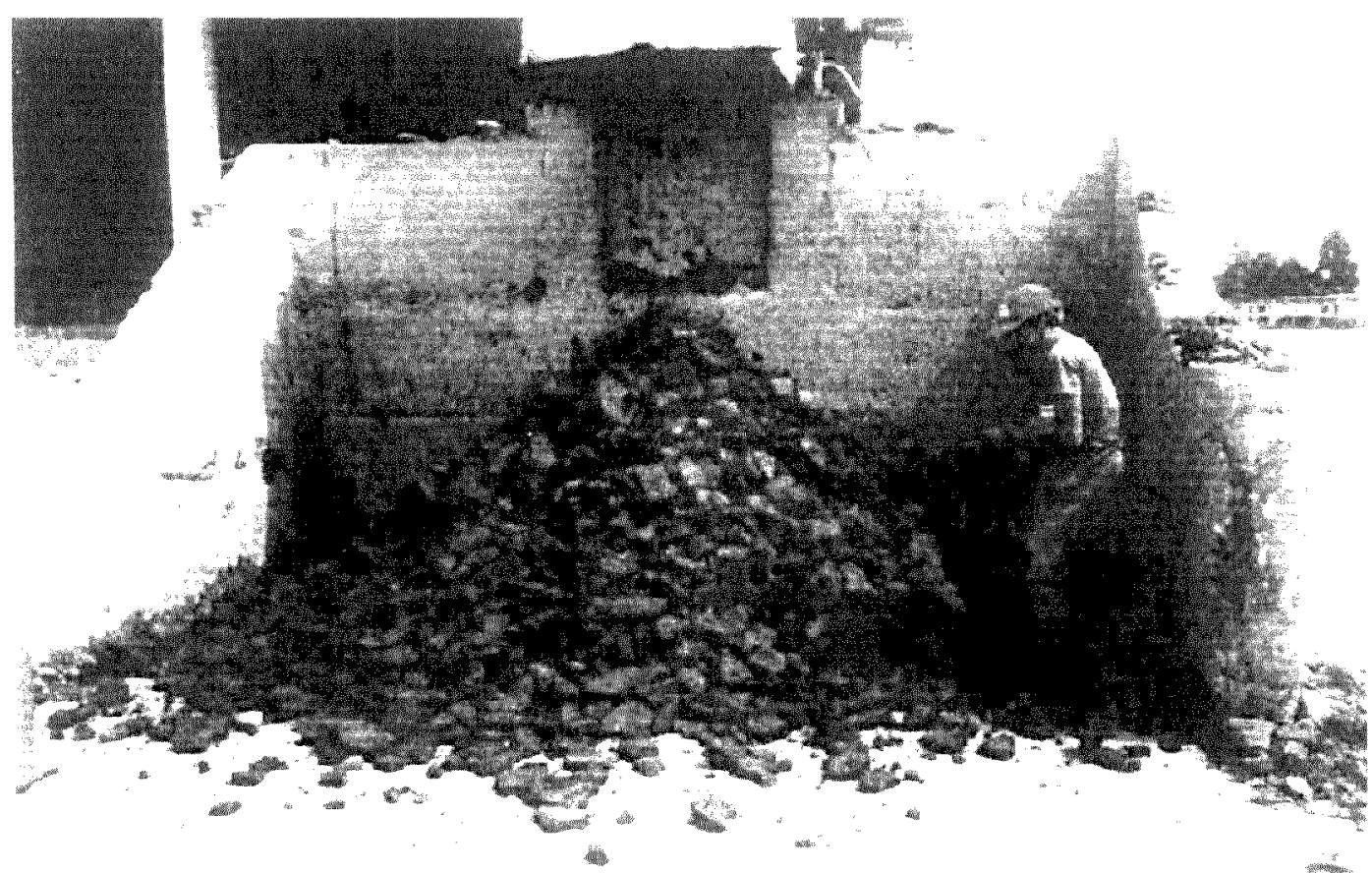

Figura 11: Descarga das tortas de lodo e coleta das amostras para as pilhas A, B, C e D

Os recipientes com $30 \mathrm{~kg}$ de amostras e o conteúdo de um deles aparece nas fotos seguintes. Simultaneamente à formação dessas amostras, como mencionado, a cada descarga do filtro foi também retirada uma amostra de cerca de $200 \mathrm{~g}$ e enviada ao laboratório em frasco fechado, exclusivamente para determinação da massa seca (vide Anexo B com esquema ilustrativo da coleta) 


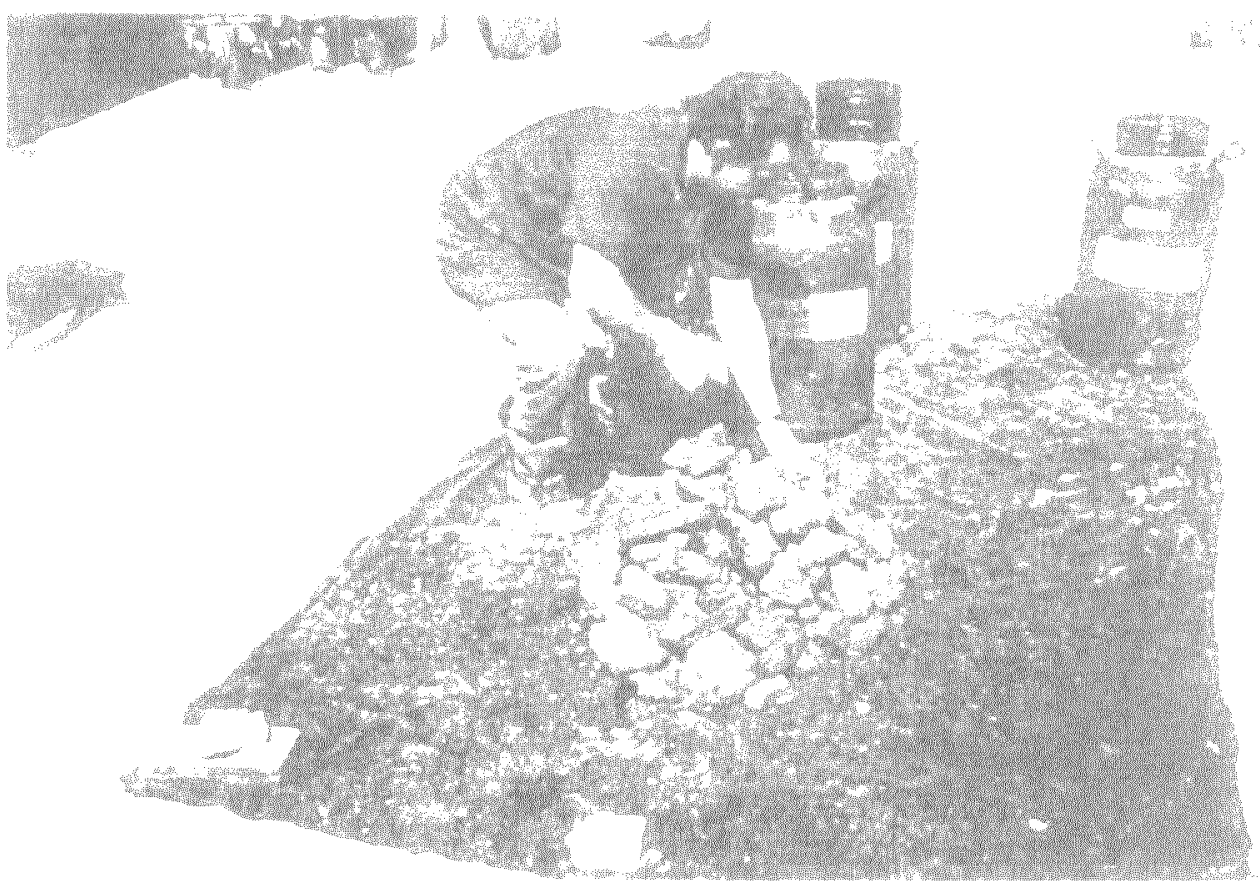

Figura 12: Recipientes para amostras A,B, C, D e amostra C fora do seu recipiente.

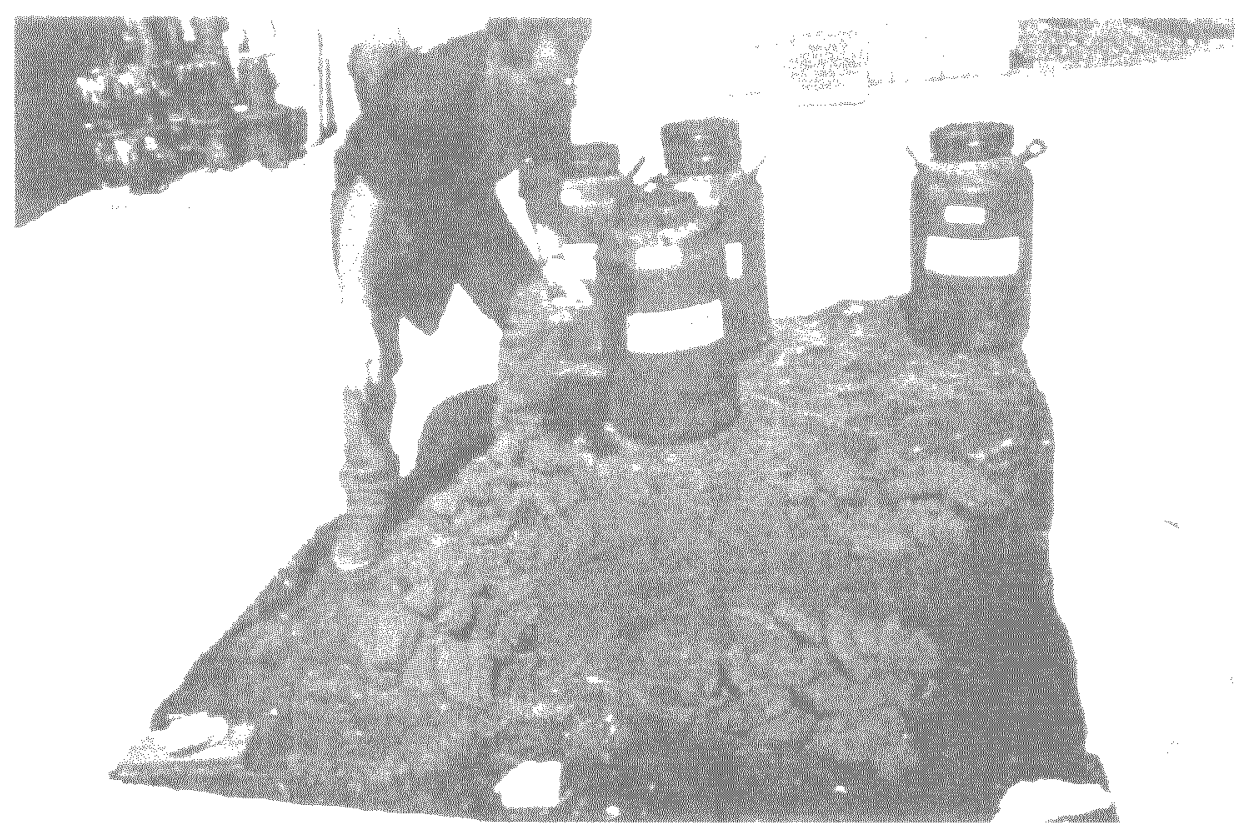

Figura 13: Quarteamento das amostras e eliminação de duas frações, conforme a NBR 10007 - Amostragem de Resíduos 
A operação retratada acima para a amostra $C$ foi também feita para as amostras $A, B$ e D. Para cada uma dessas amostras foram obtidas duas parcelas, como mostrado na foto da Figura 13 para a amostra C. Uma das parcelas de cada amostra foi remetida ao laboratório e a outra, de cada amostra, foi misturada com as equivalentes das outras pilhas, gerando a amostra $R$, representativa das $400 t(4 \times 100 t=A+B+C+D)$.

\subsubsection{Formação das pilhas para execução das pistas experimentais e análises para uso agrícola do biossólido (précondicionamento: cal)}

No espaço do pátio da ETE Barueri entre o edificio dos filtros e a cerca que delimita a propriedade ao longo do canal do rio Tietê, o terreno foi raspado, nivelado e preparado, para receber as pistas que iriam simular o comportamento das tortas sob o tráfego de veículos nos aterros reais. A Figura 14 mostra a área onde seriam construídas as pistas com as pilhas $\mathrm{E}$ e $\mathrm{F}$, como detalhado posteriormente.

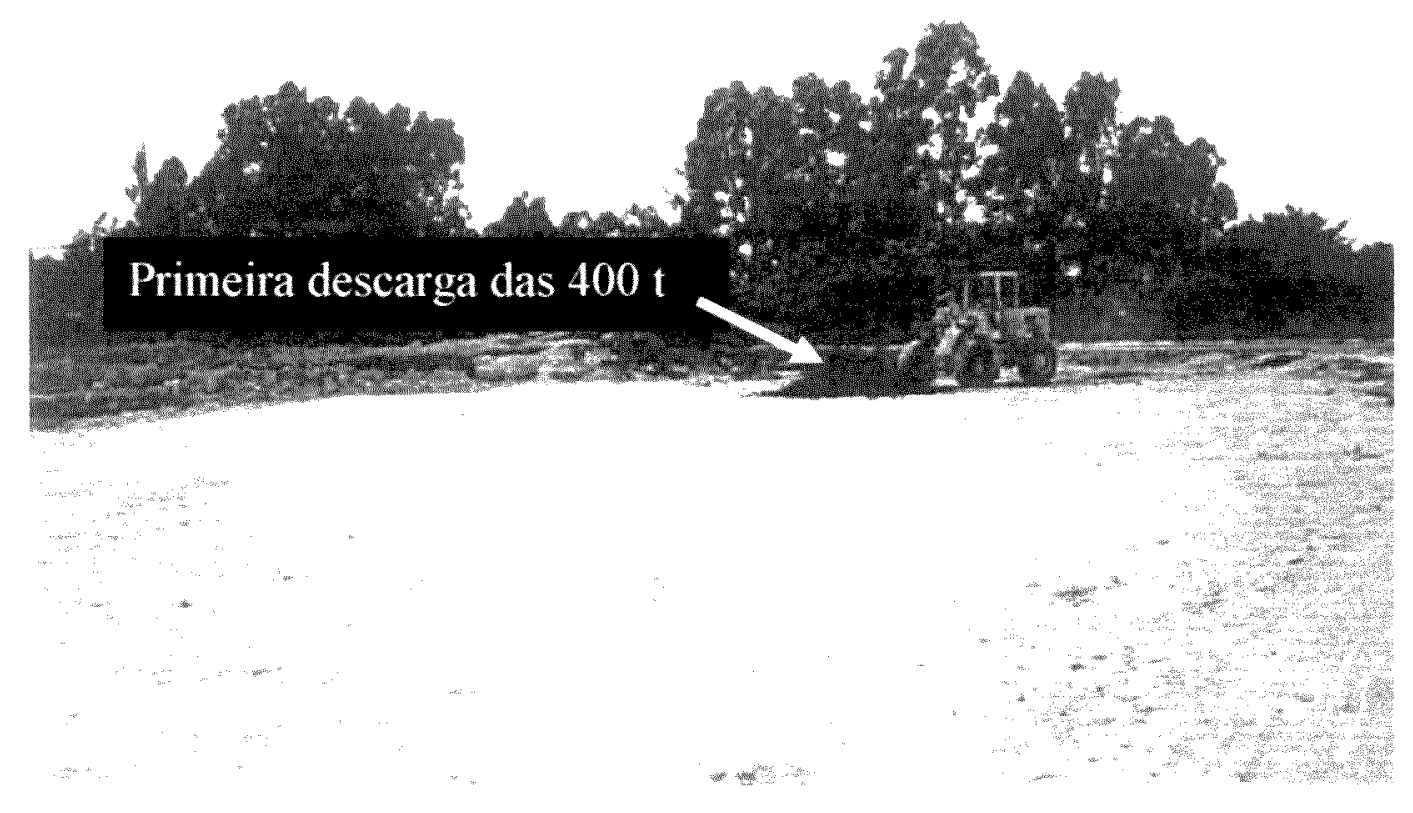

Figura 14 Pá mecânica de pneus descarregando a torta no terreno da pista 


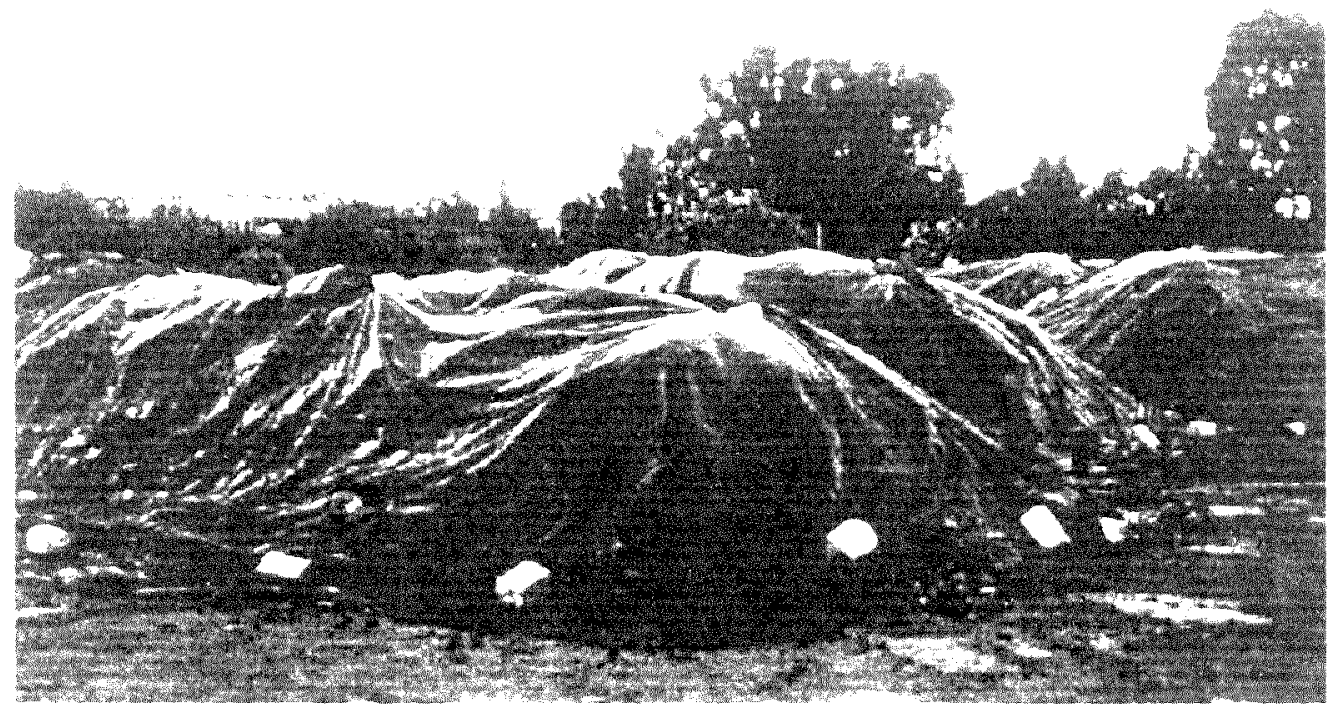

Figura 15 Pilhas A, B, C, D formadas e protegidas com plástico contra chuva. Abaixo, a pilha B foi descoberta e removida parcialmente.

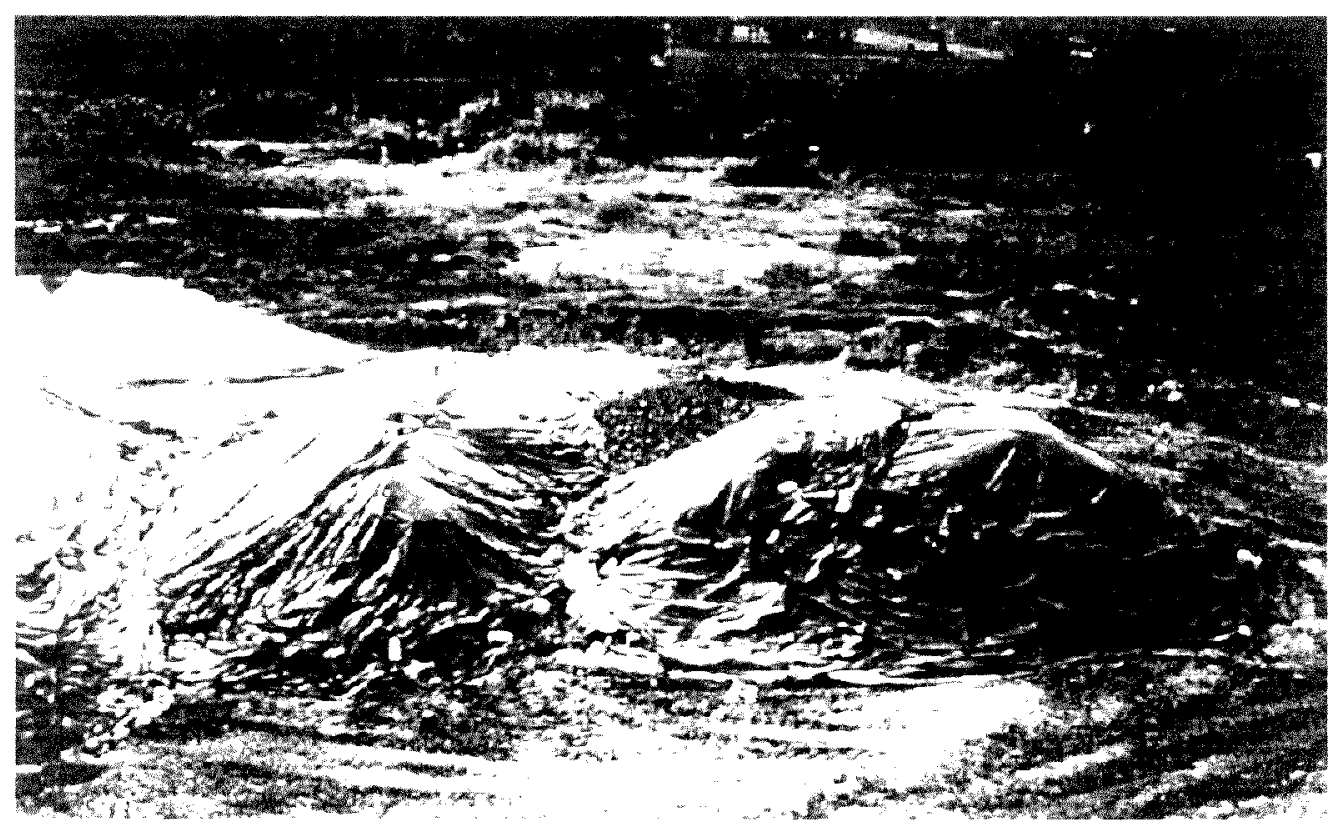




\subsubsection{Critérios normativos para avaliação dos resultados das análises tendo em vista o uso agricola das tortas}

Foi examinada a adequação do lodo para o uso agrícola verificando-se se as concentrações de poluentes estavam dentro dos limites para a Classe II - resíduo não inerte pelos critérios da NBR 10.004 e se as concentrações de metais estavam abaixo das estipulados pela norma 40 CFR - Parte 503 - USEPA (ou P 4230 da Cetesb).

A presença de fenóis não é considerada pelas normas norte-americanas ou da Cetesb como critério impeditivo do uso agricola. Verificou-se que a adição complementar de cal virgem à torta para fins de construção da pista CAL-01 e CAL-03 (vide Tabelas $14 \mathrm{e}$

18) revelou concentrações de fenóis respectivamente de $16,2 \mathrm{mg} / \mathrm{kg}$ e $15,86 \mathrm{mg} / \mathrm{kg}$, acima portanto dos $10 \mathrm{mg} / \mathrm{kg}$ admissiveis pela NBR 10004 , donde o residuo passou a ser classe I. O mesmo ocorreu para a pista ABS + CAL 01 (vide Tabela 22), que recebeu a mistura de cal mais Absorsol, nas proporções respectivas de 8 e $4 \%$ e que liberou 15,43 $\mathrm{mg} / \mathrm{kg}$ fenóis.

Conclui-se que haveria necessidade de consulta específica à Cetesb antes de usá-lo como condicionador de solos, se por algum motivo as tortas que tivessem recebido cal adicional não fossem efetivamente para o aterro exclusivo.

\subsubsection{Resultados das análises físico-químicas e microbiológicas na amostra $R$}

As tortas formadoras das pilhas A, B, C e D foram provenientes de quaisquer dos filtros, com duas retiradas de manhã e duas à tarde de cada dia, para determinação da concentração média de sólidos de cada pilha. Para cada uma foram tabelados os dados de data, hora, filtro contribuinte, concentração de sólidos de três pontos diferentes da descarga e concentração da descarga, como indicado na Tabela 4. 
Tabela 4: Datas de coleta e concentração de sólidos das tortas

(Amostra R $=\mathrm{A}+\mathrm{B}+\mathrm{C}+\mathrm{D})$

\begin{tabular}{|c|c|c|c|c|c|c|c|}
\hline \multirow{2}{*}{ Pilha } & \multirow{2}{*}{$\begin{array}{c}\text { Ano } \\
1998 \\
24 / a b r\end{array}$} & \multirow{2}{*}{$\begin{array}{l}\text { Hora } \\
11: 50\end{array}$} & \multirow{2}{*}{$\begin{array}{r}\text { Filtro } \\
2\end{array}$} & \multicolumn{3}{|c|}{ Teor de MS em \% } & \multirow{2}{*}{$\begin{array}{c}\begin{array}{c}\text { TS \% } \\
\text { médio }\end{array} \\
37,0\end{array}$} \\
\hline & & & & 37,2 & 36,9 & 37,0 & \\
\hline & $24 / a b r$ & $12: 10$ & 3 & 34,3 & 34,8 & 35,0 & 34,7 \\
\hline \multirow[t]{5}{*}{$A$} & 24/abr & $13: 20$ & 1 & 36,1 & 34,9 & 36,3 & 35,8 \\
\hline & $24 / a b r$ & $16: 00$ & 2 & 32,4 & 33,5 & 33,8 & 33,1 \\
\hline & $27 / \mathrm{abr}$ & $13: 50$ & 3 & 35,2 & 35,2 & 36,1 & 35,5 \\
\hline & 27/abr & $14: 20$ & 1 & 36,2 & 36,6 & 36,1 & 36,3 \\
\hline & $27 / a b r$ & $15: 20$ & 2 & 35,0 & 35,0 & 35,0 & 35,0 \\
\hline \multirow[t]{5}{*}{$\mathrm{B}$} & $28 / a b r$ & $09: 40$ & 3 & 32,7 & 32,2 & 37,7 & 34,2 \\
\hline & 28/abr & $11: 00$ & 2 & 33,5 & 33,7 & 34,0 & 33,7 \\
\hline & $28 / a b r$ & $13: 00$ & 1 & 35,7 & 35,7 & 35,5 & 35,6 \\
\hline & $28 / a b r$ & $14: 45$ & 3 & 36,0 & 36,6 & 36,5 & 36,4 \\
\hline & 28/abr & $15: 30$ & 2 & 36,2 & 35,9 & 36,0 & 36,0 \\
\hline \multirow[t]{5}{*}{$\mathrm{C}$} & 28/abr & $17: 20$ & 1 & 34,1 & 34,9 & 34,1 & 34,4 \\
\hline & $28 / a b r$ & 19:00 & 3 & 35,0 & 35,6 & 35,9 & 35,5 \\
\hline & $28 / a b r$ & $19: 50$ & 2 & 40,0 & 40,4 & 39,8 & 40,1 \\
\hline & 29/abr & $12: 20$ & 1 & 36,7 & 36,8 & 36,8 & 36,8 \\
\hline & 29/abr & $13: 30$ & 2 & 36,6 & 36,9 & 37,0 & 36,8 \\
\hline \multirow[t]{3}{*}{$\mathrm{D}$} & 29/abr & $13: 50$ & 3 & 35,5 & 35,3 & 34,8 & 35,2 \\
\hline & $29 / a b r$ & $15: 50$ & 1 & 33,4 & 33,7 & 33,3 & 33,5 \\
\hline & 29/abr & $17: 05$ & 2 & 34,3 & 33,6 & 34,4 & 34,1 \\
\hline
\end{tabular}

Com o lodo da amostra $\mathrm{R}$, formada como explicado, inicialmente foram realizados os exames fisicos químicos previstos na NBR 10.004 determinando-se em $50 \mathrm{~g}$ da amostra:

- $\mathrm{O} \mathrm{pH}$ inicial e final

- A umidade da amostra

- Os seguintes resultados em $\mathrm{mg} / \mathrm{Kg}$ na massa bruta: 
Óleos e graxas, aluminio, arsênio, bário, berilio, cádmio, chumbo, cobre, cromo total, cromo hexavalente, manganês, mercuirio, prata, selênio, sódio, zinco, niquel, ferro, cianetos, cloretos, fenóis, vanádio, surfactantes, cobalto, antimônio e molibdênio.

- Os seguintes resultados em $\mathrm{mg} / \mathrm{L}$ de uma solução $0,5 \mathrm{~N}$ de $200 \mathrm{~mL}$ do lixiviado após 24 horas:

Arsênio, bário, cádmio, chumbo, cromo total, mercuirio, prata, selênio e fluoretos

- Análises parasitológicas e microbiológicas :

NMP/100 g de coliformes totais, NMP/100 g de coliformes fecais, Salmonellas sp.em $25 \mathrm{~g}$, UFC/100 g de colifagos e pesquisa da presença e viabilidade de ovos de helmintos.

Os resultados encontram-se nas Tabelas 5 e 6. 
Tabela 5: $\quad$ Análises físico-químicas na amostra R (NBR 10.004)

Umidadc: $60,80 \%$. Laboratório Puriquima Ltda

Laudo: 12/5/1998 - Amostra 9643

\begin{tabular}{|c|c|c|c|c|c|}
\hline \multirow[b]{2}{*}{ Parâmctros } & \multicolumn{2}{|c|}{ Massa Bruta } & \multicolumn{2}{|c|}{ Lixiviado } & \multirow[b]{2}{*}{$\begin{array}{l}\text { Ensaio de } \\
\text { Lixiviação }\end{array}$} \\
\hline & $\begin{array}{l}\text { Resultados } \\
\mathrm{mg} / \mathrm{kg}\end{array}$ & $\begin{array}{l}\mathrm{VMP} \\
\mathrm{mg} / \mathrm{kg}\end{array}$ & $\begin{array}{c}\text { Resultados } \\
\mathrm{mg} / \mathrm{l}\end{array}$ & $\begin{array}{l}\mathrm{VMP} \\
\mathrm{mg} / \mathrm{l}\end{array}$ & \\
\hline Óleos e Graxas & $1,3 \%$ & $5 \%$ & $\mathrm{x}$ & - & \multirow{3}{*}{$\begin{array}{c}\mathrm{pH} \text { Inicial } \\
11,61\end{array}$} \\
\hline Alumínio & $\mathrm{x}$ & - & $\mathrm{x}$ & - & \\
\hline Arsĉnio & $<5$ & 1000 & $<0,5$ & 5 & \\
\hline Bário & 274 & - & 7,1 & 100 & \multirow{3}{*}{$\begin{array}{c}\text { pH Final } \\
6,33\end{array}$} \\
\hline Berilio & $<2$ & 100 & $x$ & -- & \\
\hline Cádmio & 4 & - & $<0,02$ & 0,5 & \\
\hline Chumbo & 82 & $\star \star *$ & $<0,05$ & 5 & \multirow{6}{*}{$\begin{array}{c}\text { Massa da } \\
\text { Amostra } \\
50 \mathrm{~g} \\
\text { (base seca) }\end{array}$} \\
\hline Cobre & 180 & - & $x$ & -- & \\
\hline Cromo Total & 200 & - & $<0,02$ & 5 & \\
\hline Cromo Hexav. & 4 & 100 & $x$ & - & \\
\hline Manganês & $x$ & - & $x$ & - & \\
\hline Mercúrio & 0,5 & 100 & $<0,001$ & 0,1 & \\
\hline Prata & 18 & - & $<0,01$ & 5 & \multirow{5}{*}{$\begin{array}{c}\text { Volume Hac } \\
0,5 \mathrm{~N} \\
200 \mathrm{ml}\end{array}$} \\
\hline Selênio & $<1$ & 100 & $<0,5$ & 1 & \\
\hline Sódio & $\mathrm{x}$ & - & $x$ & -- & \\
\hline Zinco & 720 & - & $\mathrm{x}$ & - & \\
\hline Niquel & 92 & - & $\mathrm{x}$ & - & \\
\hline Ferro & $x$ & - & $\mathrm{x}$ & - & \multirow{14}{*}{$\begin{array}{c}\text { Tempo de } \\
\text { ensaio } \\
24 \mathrm{~h}\end{array}$} \\
\hline Cianetos & $<0,02$ & 1000 & $\mathrm{x}$ & - & \\
\hline Cloretos & $x$ & - & $\mathrm{x}$ & - & \\
\hline Dureza & $x$ & - & $x$ & $\ldots$ & \\
\hline Fenóis & 2,03 & 10 & $x$ & - & \\
\hline Fluoretos & $x$ & - & 0,1 & 150 & \\
\hline Vanádio & 18 & 1000 & $\mathrm{x}$ & $\ldots$ & \\
\hline Nitratos & $\mathrm{x}$ & - & $\mathrm{x}$ & - & \\
\hline Sulfatos & $x$ & - & $x$ & - & \\
\hline Surfactantes & $\mathrm{x}$ & $-\cdots$ & $\mathrm{x}$ & - & \\
\hline & & & & & \\
\hline Cobalto & 8 & -- & $\mathrm{x}$ & - & \\
\hline Antimônio & $<5$ & - & $\mathrm{x}$ & - & \\
\hline Molibdênio & 8 & - & $\mathrm{x}$ & - & \\
\hline
\end{tabular}

1- $\left({ }^{* *}\right)=$ Limite para o chumbo em composto orgânicos $=100 \mathrm{mg} \mathrm{Pb} / \mathrm{kg}$.

2- $\mathrm{VMP}=$ Valores máximos permitidos. 
Os resultados da caracterização microbiológica da amostra R encontram-se na tabela 5 .

Tabela 6: $\quad$ Análises microbiológicas na amostra $\mathbf{R}$

Laboratório Puriquima Ltda

Laudo: 12/5/1998 - LP 689-98

\begin{tabular}{|c|c|c|c|c|}
\hline $\begin{array}{c}\text { Coliforme } \\
\text { Total } \\
\text { NMP/ } 100 \mathrm{~g}\end{array}$ & $\begin{array}{c}\text { Coliforme } \\
\text { Fecal } \\
\text { NMP/ } 100 \mathrm{~g}\end{array}$ & $\begin{array}{c}\text { Salmonela cm } \\
25 \mathrm{~g}\end{array}$ & $\begin{array}{c}\text { Pesquisa de ovos } \\
\text { de Helmintos }\end{array}$ & $\begin{array}{c}\text { Colifagos } \\
\text { UFC/100g }\end{array}$ \\
\hline & & & & \\
\hline & 43 & 0 & Ausente & Ausente \\
\hline
\end{tabular}

NMP - número mais provável; UFC - unidade formadora de colônia.

$17^{\text {th }} \mathrm{ed}$. "STANDARD METHODS For the Examination of Water and Wastewater", APHA, AWWA, EPCF. 


\subsubsection{Formação e análises da pilha $E$ antes do acréscimo de aditivos}

Com os mesmos procedimentos de amostragem e controles utilizados para as pilhas $\mathrm{A}, \mathrm{B}, \mathrm{C} \mathrm{e}$, foi formada a pilha de torta do filtro-prensa E, com cerca de 100t. para posterior acréscimo do aditivo Absorsol e também cal virgem $\mathrm{cm}$ várias proporções.

O equipamento utilizado para fazcr a mistura $\mathrm{c} \mathrm{cm}$ que proporção a mistura foi feita encontramse descritos mais adiante. juntamente com a descrição da construção das pistas.

$O$ presente item traz os resultados das análises da pilha $E$ com a torta précondicionada com cal e cloreto férrico ainda sem aditivos adicionais.

Tabela 7: Datas de coleta e concentração de sólidos das tortas

(Amostra $E=$ antes do acréscimo de Absorsol/cal adicional)

\begin{tabular}{cccccccc}
\hline Pilha & $\begin{array}{c}\text { Ano } \\
\text { 1998 }\end{array}$ & Hora & Filtro & \multicolumn{2}{c}{ Teor de MS em \% } & $\begin{array}{c}\text { TS \% } \\
\text { médio }\end{array}$ \\
\hline \multirow{4}{*}{ E } & $04 / 05$ & $12: 30$ & 2 & 35,3 & 35,0 & 34,9 & 35,1 \\
& $04 / 05$ & $13: 30$ & 1 & 34,5 & 34,7 & 34,4 & 34,5 \\
& $04 / 05$ & $14: 20$ & 3 & 38,7 & 38,6 & 38,8 & 38,7 \\
& $04 / 05$ & $17: 00$ & 2 & 32,4 & 32,6 & 32,5 & 32,5 \\
& $04 / 05$ & $17: 30$ & 1 & 31,6 & 31,7 & 31,7 & 31,7 \\
\hline
\end{tabular}


Tabcla 8: Análises físico-químicas na amostra E (NBR 10.004)

Umidade: $55,92 \%$. Laboratório Puriquima Lida

Laudo: 26/5/1998 - Amostra 9809

\begin{tabular}{|c|c|c|c|c|c|} 
Parâmetros & $\begin{array}{c}\text { Massa Bruta } \\
\text { Resultados }\end{array}$ & $\begin{array}{c}\text { VMP } \\
\text { mg/kg }\end{array}$ & Resultados & VMP & Ensaio de \\
Lixiviaça
\end{tabular}

1- $\left({ }^{* *}\right)=$ Limite para o chumbo $\mathrm{cm}$ composto orgânicos $=100 \mathrm{mg} \mathrm{Pb} / \mathrm{kg}$.

2- $\mathrm{VMP}=$ Valores máximos permitidos. 
Os resultados da caracterização microbiológica da amostra $\mathrm{E}$ encontram-se na Tabela 8.

\section{Tabcla 9: Análises microbiológicas na amostra $\mathbf{E}$ Laboratório Puriquima Lida Laudo: 25/5/1998 - LP: 763 I-98}

\begin{tabular}{|c|c|c|c|c|}
\hline $\begin{array}{c}\text { Coliforme } \\
\text { Total } \\
\text { NMP/100g }\end{array}$ & $\begin{array}{c}\text { Coliforme } \\
\text { Fecal } \\
\text { NMP/100g }\end{array}$ & $\begin{array}{c}\text { Salmonela } \\
\mathrm{cm} \\
25 \mathrm{~g}\end{array}$ & $\begin{array}{c}\text { Pesquisa de } \\
\text { ovos } \\
\text { de Helmintos }\end{array}$ & $\begin{array}{c}\text { Colifagos } \\
\text { UFC } / 100 \mathrm{~g}\end{array}$ \\
\hline 4300 & $<3$-Ausente & 0 & Ausente & Ausente \\
\hline
\end{tabular}

NMP - número mais provável; UFC - unidade formadora de colônia. $17^{\text {th }} \mathrm{ed}$ "STANDARD METHODS For the Examination of Water and Wastewater", APHA, AWWA, EPCF.

\subsubsection{Formação e análises da pilha $F$ antes do acréscimo de aditivos}

Novamente seguindo a metodologia anterior (pilhas A a D e E), foi formada a pilha de torta do filtro-prensa $\mathrm{F}$, com cerca de 100t para posterior acréscimo de cal virgem em várias proporções.

O mesmo equipamento utilizado anteriormente para misturar o Absorsol foi usado para fazer a mistura do material da Pilha $\mathrm{F}$ com cal virgem. Detalhes desta operação $\mathrm{e} \mathrm{cm}$ que proporção a mistura foi feita cncontram-se no itcm 4.2.3.

$\mathrm{O}$ presente item traz os resultados das análises da pilha $\mathrm{F}$ com a torta précondicionada com cal e cloreto férrico, ainda sem aditivos adicionais. 
Tabela 10 Datas de coleta e concentração de sólidos das tortas (Amostra $F=$ antes do acréscimo adicional de cal virgem)

\begin{tabular}{cccccccc}
\hline Pilha & $\begin{array}{c}\text { Ano } \\
\text { 1998 }\end{array}$ & Hora & Filtro & \multicolumn{2}{c}{ Teor de MS em \% } & $\begin{array}{c}\text { TS \% } \\
\text { médio }\end{array}$ \\
\hline \multirow{4}{*}{ F } & $05 / 05$ & $16: 45$ & 1 & 33.3 & 33,4 & 33,1 & 33,3 \\
& $05 / 05$ & $12: 20$ & 2 & 32,2 & 32,3 & 32,3 & 32.3 \\
& $06 / 05$ & $10: 50$ & 1 & 27,4 & 27,8 & 27,7 & 27,6 \\
& $06 / 05$ & $17: 00$ & 2 & 33,3 & 32,9 & 33,8 & 33,3 \\
& $07 / 05$ & $07: 45$ & 2 & 35.4 & 35,0 & 35.2 & 35,2 \\
\hline
\end{tabular}


Tabela 11: Análises físico-químicas na amostra F (NBR 10.004)

Umidade: $61.58 \%$ Laboratório Puriquima Ltda

Laudo: 26/5/1998 - Amostra 9810

\begin{tabular}{|c|c|c|c|c|c|}
\hline \multirow[b]{2}{*}{ Parâmetros } & \multicolumn{2}{|c|}{ Massa Bruta } & \multicolumn{2}{|c|}{ Lixiviado } & \multirow[b]{2}{*}{$\begin{array}{l}\text { Ensaio de } \\
\text { Lixiviação }\end{array}$} \\
\hline & $\begin{array}{l}\text { Rcsultados } \\
\mathrm{mg} / \mathrm{kg}\end{array}$ & $\begin{array}{l}\text { VMP } \\
\mathrm{mg} / \mathrm{kg}\end{array}$ & $\begin{array}{c}\text { Resultados } \\
\mathrm{mg} / \mathrm{l}\end{array}$ & $\begin{array}{l}\text { VMP } \\
\mathrm{mg} / 1\end{array}$ & \\
\hline Olcos e Graxas & $0.96 \%$ & $5 \%$ & $x$ & - & \multirow{2}{*}{$\begin{array}{c}\mathrm{pH} \text { Inicial } \\
10,93\end{array}$} \\
\hline $\begin{array}{l}\text { Aluminio } \\
\text { Arsênio }\end{array}$ & $\begin{array}{l}x \\
<5\end{array}$ & $\overline{1000}$ & $\begin{array}{c}x \\
<0,5\end{array}$ & $\overline{5}$ & \\
\hline Bário & 220 & - & 2,0 & 100 & \multirow{3}{*}{$\begin{array}{c}\text { pH Final } \\
6,33\end{array}$} \\
\hline Berilio & $<2$ & 100 & $\mathrm{x}$ & - & \\
\hline Cádmio & 2.8 & $\ldots$ & $<0,02$ & 0.5 & \\
\hline Chumbo & 60 & $* *$ & 0,30 & 5 & \multirow{6}{*}{$\begin{array}{c}\text { Massa da } \\
\text { Amostra } \\
50 \mathrm{~g} \\
\text { (base seca) }\end{array}$} \\
\hline Cobre & 154 & - & $\mathrm{x}$ & - & \\
\hline Cromo Total & 160 & - & $<0,02$ & 5 & \\
\hline Cromo Hexay & 2 & 100 & $x$ & - & \\
\hline Manganês & $x$ & - & $\mathrm{x}$ & - & \\
\hline Mercúrio & 0.4 & 100 & $<0,001$ & 0,1 & \\
\hline Prata & 14 & - & $<0,01$ & 5 & \multirow{19}{*}{$\begin{array}{c}\text { Volume Hac } \\
0,5 \mathrm{~N} \\
200 \mathrm{ml}\end{array}$} \\
\hline Selênio & $<1$ & 100 & $<0,5$ & 1 & \\
\hline Sódio & $x$ & $-\ldots$ & $\mathrm{x}$ & - & \\
\hline Zinco & 660 & - & $\mathrm{x}$ & - & \\
\hline Níquel & 68 & - & $\mathrm{x}$ & -- & \\
\hline Ferro & $\mathrm{x}$ & -- & $x$ & - & \\
\hline Cianetos & 0.099 & 1000 & $\mathrm{x}$ & - & \\
\hline Cloretos & $x$ & - & $x$ & $\ldots$ & \\
\hline Dureza & $x$ & $\ldots$ & $\mathrm{x}$ & $\ldots$ & \\
\hline Fenóis & 3.373 & 10 & $\mathrm{x}$ & -- & \\
\hline Fluoretos & $\mathrm{x}$ & $-\cdots$ & 0.4 & 150 & \\
\hline Vanádio & 14 & 1000 & $x$ & - & \\
\hline Nitratos & $x$ & - & $\mathbf{x}$ & $\ldots$ & \\
\hline Sulfatos & $\mathrm{x}$ & - & $\mathrm{x}$ & -- & \\
\hline Surfactantes & $\mathrm{x}$ & $\ldots$ & $\mathrm{x}$ & $\ldots$ & \\
\hline & & & & & \\
\hline Antimônio & $<2$ & & & & \\
\hline Cobalto & 4 & - & $\mathrm{x}$ & - & \\
\hline Molibdênio & 6 & - & $x$ & -- & \\
\hline
\end{tabular}

1- $\left({ }^{* *}\right)=$ Limitc para o chumbo $\mathrm{em}$ composto orgânicos $=100 \mathrm{mg} \mathrm{Pb} / \mathrm{kg} . \mathrm{E}$ em compostos mincrais $=1000 \mathrm{mg} \mathrm{Pb} / \mathrm{kg}$

2- $\mathrm{VMP}=$ Valores máximos permitidos. 
Os resultados da caracterização microbiológica da amostra $\mathrm{E}$ encontram-se na Tabela 11.

Tabcla 12: Análises microbiológicas na amostra F

Laboratório Puriquima Ltda

Laudo: 25/5/1998 LP-763 2-98

\begin{tabular}{|c|c|c|c|c|}
\hline $\begin{array}{c}\text { Coliforme } \\
\text { Total } \\
\text { NMP/100g }\end{array}$ & $\begin{array}{c}\text { Coliforme } \\
\text { Fecal } \\
\text { NMP/100g }\end{array}$ & $\begin{array}{c}\text { Salmonela } \\
\text { em } \\
25 \mathrm{~g}\end{array}$ & $\begin{array}{c}\text { Pesquisa de } \\
\text { ovos } \\
\text { de Helmintos }\end{array}$ & $\begin{array}{c}\text { Colifagos } \\
\text { UFC/100g }\end{array}$ \\
\hline & & & \\
\hline
\end{tabular}

NMP - número mais provável; UFC - unidade formadora de colônia.

$17^{\text {th }} \mathrm{ed}$. "STANDARD METHODS For the Examination of Water and Wastewater", APHA, AWWA, EPCF. 


\subsubsection{Conceito das pistas com tortas das pilhas E e F. Planejamento das análises de caracterização do lodo das pistas após recebimento dos aditivos (précondicionamento: cal)}

As tortas de filtro-prensa das pilhas $\mathrm{E}$ e F, pré-condicionadas com cal e cloreto férrico, receberam os aditivos minerais cal e Absorsol e foram transportadas cerca de $300 \mathrm{~m}$ dentro da área da ETE - Barueri para construção de pistas medindo aproximadamente $30 \mathrm{~m} \times 7 \mathrm{~m} \times 0,5 \mathrm{~m}$, após o espalhamento.

A dosagem de Absorsol nas $100 \mathrm{t}$ da pilha $\mathrm{E}$ foi feita com fundamento no peso capaz de ser carregado pela pá mecânica $(2.000 \mathrm{~kg})$ e no peso do saco de Absorsol $(20 \mathrm{~kg})$. A proporção de adição na torta resultou na concentração de 7\% em peso de Absorsol. Para a pilha $F$, a mistura com a cal virgem foi feita na dosagem recomendada pelo plano diretor (17,5\% em peso, vide Tabela 3$)$, tendo sido utilizado o mesmo misturador ilustrado no item 4.1.3, Figuras 8 e 9.

Foram construidas as seguintes pistas:

- Lodo da pilha E misturado com 7\% de Absorsol ou "Pista ABS"

- Lodo da pilha F misturado com 17,5\% de cal virgem ou "Pista CAL-17,5"

- Lodo da pilha F com 5\% de cal virgem ou "Pista CAL-5"

- Lodo da pilha F com $8 \%$ de cal e com 4\% de Absorsol ou "Pista ABS +CAL"

Para caracterização físico-quimica e microbiológica do lodo após recebimento dos aditivos, foram retiradas amostras das pistas ABS, CAL-17,5 e ABS + CAL. A pista CAL-5 foi construida apenas para ensaios geotécnicos. Foram realizadas análises físicoquímicas na massa bruta, ensaios de lixiviação e exames microbiológicos para coliformes e Salmonellas sp. nas amostras retiradas a 5, 10 e 15 dias do lançamento das tortas para construção das seguintes pistas: 
- Pista de torta do filtro-prensa mais 7\% de Absorsol ou Pista ABS

As amostras retiradas aos 5,10 e 15 dias do lançamento das tortas seriam respectivamente designadas por Amostra pista ABS 1, Amostra pista ABS $2 e$ Amostra pista ABS 3. Entretanto, durante os ensaios geotécnicos na ABS 1, verificou-se que o acréscimo exclusivamente de Absorsol não viabilizava a construção. Resolveu-se então construir a pista $\mathrm{ABS}+\mathrm{CAL} 1$ e 2, como explicado na seqüência, cancelando-se as duas últimas acima (ABS 2 e 3).

- Pista de torta do filtro-prensa mais 17,5\% de cal ou Pista CAL 17,5 identificada no laboratório de química simplesmente como Pista $\mathrm{CAL}$

Semelhantemente e para os mesmos períodos após o lançamento identificadas como Amostra pista CAL 1, Amostra pista CAL 2 e Amostra pista CAL 3.

- Pista de torta do filtro-prensa mais $8 \%$ de cal mais 4\% de Absorsol ou pista Pista $\mathrm{ABS}+\mathrm{CAL}$, que substituíram as pistas exclusivamente com Absorsol como acima explicado, tendo sido designadas por Amostra pista $A B S+C A L 1 \mathrm{e}$ Amostra pista $A B S+C A L 2$.

Em resumo as pistas e o intervalo de coleta das amostras foram os seguintes:

Amostra da pista Intervalo em dias após lançamento do lodo
CAL - 1
CAL - 2 10
CAL - 3 15
ABS - 1 5
$\mathrm{ABS}+\mathrm{CAL} 1$ 5
ABS + CAL 2 10 
Os resultados de laboratório referem-se as amostras coletadas nos dias seguintes:

Tabela 13: Datas das retiradas de amostras das pistas para caracterização físico-química e microbiológica do material da plataforma

\begin{tabular}{|c|c|c|c|c|c|}
\hline Pista & $\begin{array}{l}\text { Dias } \\
\text { após } \\
\text { lanc }^{\text {to. }} \text {. }\end{array}$ & Tabela & Data & $\begin{array}{c}\% \% \\
\text { Umidade }\end{array}$ & $\begin{array}{c}\% \% \\
\text { Sólidos }\end{array}$ \\
\hline $\mathrm{C}_{3 \mathrm{l}-01}$ & 5 & & & & \\
\hline Fisico-quimica & & 14 & $04 / 06 / 1998$ & 51,11 & 48,89 \\
\hline Microbiológica & & 15 & $29 / 05 / 1998$ & & \\
\hline & & & & & \\
\hline Cal-02 & 10 & & & & \\
\hline Físico-química & & 16 & $15 / 06 / 1998$ & 50,11 & 49,89 \\
\hline Microbiológica & & 17 & $15 / 06 / 1998$ & & \\
\hline Cal-03 & 15 & & & & \\
\hline Físico-química & & 18 & $24 / 06 / 1998$ & 47,07 & 52,93 \\
\hline Microbiológica & & 19 & $24 / 06 / 1998$ & & \\
\hline ABS-01 & 5 & & & & \\
\hline Físico-química & & 20 & $04 / 06 / 1998$ & 58,24 & 41,76 \\
\hline Microbiológica & & 21 & $29 / 05 / 1998$ & & \\
\hline $\mathrm{ABS}+\mathrm{Cal} 01$ & 5 & & & & \\
\hline Físico-química & & 22 & $15 / 06 / 1998$ & 42,53 & 57,47 \\
\hline Microbiológica & & 23 & $15 / 06 / 1998$ & & \\
\hline $\mathrm{ABS}+\mathrm{Cal} 02$ & 10 & & & & \\
\hline Físico-química & & 24 & $24 / 06 / 1998$ & 58,05 & 41,95 \\
\hline Microbiológica & & 25 & $24 / 06 / 1998$ & & \\
\hline
\end{tabular}

Nota: em negrito as concentrações de sólidos mínima e máxima (ambas coincidiram com pistas que receberam o Absorsol). 
4.2.3.1 Resultados das análises físico-químicas e microbiológicas de amostras de lodo das pistas

Tabcla 14: Análises fisico-químicas na amostra da pista Cal-01 (NBR 10.004) Umidade: $51,11 \%$ Laboratório Puriquima Ltda Laudo: 4/6/1998 - Amostra 9841

\begin{tabular}{|c|c|c|c|c|c|}
\hline \multirow[b]{2}{*}{ Parâmetros } & \multicolumn{2}{|c|}{ Massa Bruta } & \multicolumn{2}{|c|}{ Lixiviado } & \multirow[b]{2}{*}{$\begin{array}{l}\text { Ensaio de } \\
\text { Lixiviação }\end{array}$} \\
\hline & $\begin{array}{c}\text { Resultados } \\
\mathrm{mg} / \mathrm{kg}\end{array}$ & $\begin{array}{l}\text { VMP } \\
\mathrm{mg} / \mathrm{kg}\end{array}$ & $\begin{array}{c}\text { Resultados } \\
\mathrm{mg} / \mathrm{l}\end{array}$ & $\begin{array}{l}\text { VMP } \\
\mathrm{mg} / \mathrm{l}\end{array}$ & \\
\hline Ólcos c Graxas & $1,00 \%$ & $5 \%$ & $\mathrm{x}$ & - & \multirow{3}{*}{$\begin{array}{c}\mathrm{pH} \text { Inicial } \\
12,62\end{array}$} \\
\hline Aluminio & $x$ & $-\ldots$ & $x$ & - & \\
\hline Arsênio & $<5$ & 1000 & $<0,5$ & 5 & \\
\hline Báno & 254 & - & 5,2 & 100 & \multirow{3}{*}{$\begin{array}{c}\text { pH Final } \\
12,31\end{array}$} \\
\hline Berilio & $<2$ & 100 & $\mathrm{x}$ & - & \\
\hline Cádmio & 3,2 & - & 0,06 & 0,5 & \\
\hline Chumbo & 62 & $* \star$ & $<0,05$ & 5 & \multirow{6}{*}{$\begin{array}{c}\text { Massa da } \\
\text { Amostra } \\
50 \mathrm{~g} \\
\text { (base seca) }\end{array}$} \\
\hline Cobre & 156 & - & $\mathrm{x}$ & - & \\
\hline Cromo Total & 156 & $\ldots$ & $<0,02$ & 5 & \\
\hline Cromo Hexav. & 5 & 100 & $x$ & $\cdots$ & \\
\hline Manganês & $\mathrm{x}$ & - & $\mathrm{x}$ & - & \\
\hline Mercúrio & 0,5 & 100 & $<0.01$ & 0,1 & \\
\hline Prata & 13 & - & $<0,01$ & 5 & \multirow{5}{*}{$\begin{array}{c}\text { Volume HAc } \\
0,5 \mathrm{~N} \\
200 \mathrm{ml}\end{array}$} \\
\hline Selênio & $<1$ & 100 & $<0,5$ & 1 & \\
\hline Sódio & $x$ & - & $x$ & - & \\
\hline Zinco & 680 & - & $\mathrm{x}$ & - & \\
\hline Niquel & 60 & - & $\mathrm{x}$ & - & \\
\hline Ferro & $x$ & - & $\mathrm{x}$ & - & \multirow{13}{*}{$\begin{array}{c}\text { Tempo de } \\
\text { ensaio } \\
24 \mathrm{~h}\end{array}$} \\
\hline Cianctos & 0,195 & 1000 & $x$ & - & \\
\hline Cloretos & $x$ & - & $\mathrm{x}$ & $\ldots$ & \\
\hline Dureza & $x$ & - & $x$ & $\cdots$ & \\
\hline Fenóis & 16,2 & 10 & $x$ & - & \\
\hline Fluoretos & $x$ & - & $<0,1$ & 150 & \\
\hline Vanádio & 20 & 1000 & $x$ & $-\cdots$ & \\
\hline Nitratos & $\mathrm{x}$ & - & $\mathrm{x}$ & - & \\
\hline Sulfatos & $\mathrm{x}$ & - & $x$ & - & \\
\hline Surfactantes & $\mathrm{x}$ & - & $\mathrm{x}$ & $\ldots$ & \\
\hline Antimônio & $<2$ & -- & $\mathrm{x}$ & -- & \\
\hline Cobalto & 4 & $\cdots$ & $\mathrm{x}$ & - & \\
\hline Molibdênio & 6 & -- & $\mathrm{x}$ & - & \\
\hline
\end{tabular}

1- $\left({ }^{* *}\right)=$ Limite para o chumbo $\mathrm{em}$ composto orgânicos $=100 \mathrm{mg} \mathrm{Pb/kg.} \mathrm{c}$ em compostos minerais $=1000 \mathrm{mg} \mathrm{Pb} / \mathrm{kg}$

2- $\mathrm{VMP}=$ Valores máximos permitidos. 
Tabcla 15: Análises microbiológicas na amostra da pista de Cal -01

Laboratóno Puriquima Ltda

Laudo: 29/5/1998 LP-781/1-98

\begin{tabular}{|c|c|c|c|}
\hline Amostra & $\begin{array}{c}\text { Coliforme } \\
\text { Total } \\
\text { NMP/100g }\end{array}$ & $\begin{array}{c}\text { Coliforme } \\
\text { Fecal } \\
\text { NMP/100g }\end{array}$ & $\begin{array}{c}\text { Salmoncla } \\
\mathrm{cm} \\
25 \mathrm{~g}\end{array}$ \\
\hline
\end{tabular}

NMP - númcro mais provável: UFC - unidade formadora de colônia. $17^{\text {th }} \mathrm{ed}$. "STANDARD METHODS For the Examination of Water and Wastewater", APHA, AWWA, EPCF.

A torta na data da amostragem de $12 / 5 / 1998$, foi considerada resíduo perigoso pelo laudo do Laboratório Puriquima de 6/6/1998 (LP: 781/1-98) devido à liberação de fenóis. Transcreve-se:

[...] ]o resíduo não atende os limites impostos pela norma 10.004 , na massa bruta dos seguintes parâmetros:

MASSA BRUTA: fenol

Classificação:

$O$ resíduo devido suas características obtidas nas análises fisico-químicos dos ensaios realizados conforme a norma NBR 10.004 pode ser classificado como Classe I - resíduo sólido perigoso"

Disposição:

$O$ residuo deve ser acondicionado em tambores ou caçambas fechadas e identificadas como RESÍDUO SÓLIDO PERIGOSO e disposto em ATERRO INDISTRIAL Classe I ou INCINERADO, OU RECICLADO. 
Tabcla 16: Análises físico-químicas na amostra da pista Cal-02 (NBR 10.004)

Umidade: $50,11 \%$ Laboratório Puriquima Ltda

Laudo: 15/6/1998 - Amostra 10095

\begin{tabular}{|c|c|c|c|c|c|}
\hline \multirow[b]{2}{*}{ Parâmetros } & \multicolumn{2}{|c|}{ Massa Bruta } & \multicolumn{2}{|c|}{ Lixiviado } & \multirow[b]{2}{*}{$\begin{array}{l}\text { Ensaio de } \\
\text { Lixiviação }\end{array}$} \\
\hline & $\begin{array}{l}\text { Resultados } \\
\mathrm{mg} / \mathrm{kg}\end{array}$ & $\begin{array}{l}\mathrm{VMP} \\
\mathrm{mg} / \mathrm{kg}\end{array}$ & $\begin{array}{c}\text { Resultados } \\
\mathrm{mg} / \mathrm{l}\end{array}$ & $\begin{array}{l}\text { VMP } \\
\mathrm{mg} / \mathrm{l}\end{array}$ & \\
\hline Óleos e Graxas & $0.54 \%$ & $5 \%$ & $x$ & - & \multirow{6}{*}{$\begin{array}{c}\text { pH Inicial } \\
12,67\end{array}$} \\
\hline Aluminio & $x$ & - & $x$ & - & \\
\hline Arsênio & $<5$ & 1000 & $<0,5$ & 5 & \\
\hline Bário & 460 & - & 14,9 & 100 & \\
\hline Berilio & $<2$ & 100 & $x$ & - & \\
\hline Cádmio & 3.2 & - & $<0,02$ & 0,5 & \\
\hline Chumbo & 146 & $* \star$ & $<0.05$ & 5 & \multirow{6}{*}{$\begin{array}{l}\text { Massa da } \\
\text { Amostra } \\
50 \mathrm{~g} \\
\text { (base seca) }\end{array}$} \\
\hline Cobre & 122 & $\ldots$ & $x$ & $\ldots$ & \\
\hline Cromo Total & 148 & -- & 2,4 & 5 & \\
\hline Cromo Hexav. & $<1$ & 100 & $\mathrm{x}$ & -- & \\
\hline Manganês & $x$ & $-\ldots$ & $x$ & - & \\
\hline Mercúno & $<0.1$ & 100 & $<0,001$ & 0,1 & \\
\hline Prata & 12 & - & $<0,01$ & 5 & \multirow{4}{*}{$\begin{array}{c}\text { Volume HAc } \\
0,5 \mathrm{~N} \\
200 \mathrm{ml}\end{array}$} \\
\hline Selênio & $<1$ & 100 & $<0,5$ & 1 & \\
\hline Sódio & $\mathrm{x}$ & - & $x$ & -- & \\
\hline Zinco & 580 & -- & $x$ & - & \\
\hline Níquel & 68 & - & $\mathrm{x}$ & - & \multirow{15}{*}{$\begin{array}{c}\text { Tempo de } \\
\text { ensaio } \\
24 h\end{array}$} \\
\hline Ferro & $\mathrm{x}$ & -- & $\mathrm{x}$ & - & \\
\hline Cianetos & 0,158 & 1000 & $\mathrm{x}$ & -- & \\
\hline Cloretos & $x$ & $\ldots$ & $x$ & - & \\
\hline Dureza & $x$ & - & $x$ & -- & \\
\hline Fenóis & 6.088 & 10 & $x$ & $\cdots$ & \\
\hline Fluoretos & $x$ & $-\ldots$ & $<0,1$ & 150 & \\
\hline Vanádio & 20 & 1000 & $x$ & - & \\
\hline Nitratos & $\mathrm{x}$ & - & $x$ & - & \\
\hline Sulfatos & $\mathrm{x}$ & - & $\mathrm{x}$ & $\cdots-$ & \\
\hline Surfactantes & $\mathrm{x}$ & $\ldots$ & $\mathrm{x}$ & - & \\
\hline & & & & & \\
\hline Antimônio & $<2$ & - & $\mathrm{x}$ & - & \\
\hline Cobalto & 4 & - & $\mathrm{x}$ & - & \\
\hline Molibdênio & 16 & $\cdots$ & $\mathrm{x}$ & $\cdots$ & \\
\hline
\end{tabular}

1- $\left({ }^{* *}\right)=$ Limite para o chumbo em composto orgânicos $=100 \mathrm{mg} \mathrm{Pb} / \mathrm{kg}$. e $\mathrm{em}$ compostos minerais $=1000 \mathrm{mg} \mathrm{Pb} / \mathrm{kg}$

2- $\mathrm{VMP}=$ Valores máximos permitidos. 
Tabcla 17: Análises microbiológicas na amostra da pista de Cal -02

Laboratório Puriquima Lida

Laudo: $15 / 6 / 1998$ LP-867/1-98

\begin{tabular}{|c|c|c|c|}
\hline Amostra & $\begin{array}{c}\text { Coliforme } \\
\text { Total } \\
\text { NMP/100g }\end{array}$ & $\begin{array}{c}\text { Coliforme } \\
\text { Fecal } \\
\text { NMP/100g }\end{array}$ & $\begin{array}{c}\text { Salmonela } \\
\mathrm{cm} \\
25 \mathrm{~g}\end{array}$ \\
\hline 10095 & $<3$ Ausente & $<3$ Ausentc & Auscnte \\
\hline
\end{tabular}

NMP - número mais provável: UFC - unidade formadora de colônia.

$17^{\text {th }} \mathrm{ed}$. "STANDARD METHODS For the Examination of Water and Wastewater". APHA, AWWA, EPCF. 
Tabcla 18: Análises físico-químicas na amostra da pista Cal-03 (NBR 10.004) Umidade: $47,07 \%$ Laboratório Puriquima Lida Laudo: 24/6/1998 - Amostra 10200

\begin{tabular}{|c|c|c|c|c|c|}
\hline \multirow[b]{2}{*}{ Parâmctros } & \multicolumn{2}{|c|}{ Massa Bruta } & \multicolumn{2}{|c|}{ Lixiviado } & \multirow[b]{2}{*}{$\begin{array}{l}\text { Ensaio de } \\
\text { Lixiviação }\end{array}$} \\
\hline & $\begin{array}{c}\text { Resultados } \\
\mathrm{mg} / \mathrm{kg}\end{array}$ & $\begin{array}{l}\text { VMP } \\
\mathrm{mg} / \mathrm{kg}\end{array}$ & $\begin{array}{c}\text { Resultados } \\
\mathrm{mg} / \mathrm{l}\end{array}$ & $\begin{array}{l}\text { VMP } \\
\mathrm{mg} / \mathrm{l}\end{array}$ & \\
\hline Óleos c Graxas & $1,06 \%$ & $5 \%$ & $\mathrm{x}$ & -- & \multirow{3}{*}{$\begin{array}{c}\mathrm{pH} \text { Inicial } \\
12,91\end{array}$} \\
\hline Alumínio & $x$ & - & $x$ & $\cdots$ & \\
\hline Arsĉnio & $<5$ & 1000 & $<0.5$ & 5 & \\
\hline Bário & 300 & $-\ldots$ & 13.0 & 100 & \multirow{3}{*}{$\begin{array}{c}\text { pH Final } \\
12,97\end{array}$} \\
\hline Berilio & $<2$ & 100 & $x$ & $\ldots$ & \\
\hline Cádmio & 3,6 & $-\ldots$ & $<0,02$ & 0,05 & \\
\hline Chumbo & 58 & - & $<0,05$ & 5 & \multirow{6}{*}{$\begin{array}{l}\text { Massa da } \\
\text { Amostra } \\
50 \mathrm{~g} \\
\text { (base seca) }\end{array}$} \\
\hline Cobre & 134 & - & $x$ & - & \\
\hline Cromo Total & 158 & - & $<0,02$ & 5 & \\
\hline Cromo Hexav. & 2 & 100 & $x$ & $\ldots$ & \\
\hline Manganês & $\mathrm{x}$ & - & $\mathrm{x}$ & $\cdots$ & \\
\hline Mercúrio & 0,4 & 100 & $<0,001$ & 0,1 & \\
\hline Prata & 14 & - & $<0,01$ & 5 & \multirow{5}{*}{$\begin{array}{c}\text { Volume HAc } \\
0,5 \mathrm{~N} \\
200 \mathrm{ml}\end{array}$} \\
\hline Selênio & $<1$ & 100 & $<0,5$ & 1 & \\
\hline Sódio & $x$ & $-\ldots$ & $\mathrm{x}$ & $\ldots$ & \\
\hline Zinco & 660 & - & $x$ & -- & \\
\hline Niquel & 70 & - & $x$ & $\ldots$ & \\
\hline Ferro & $x$ & $\ldots$ & $\mathrm{x}$ & - & \multirow{13}{*}{$\begin{array}{l}\text { Tempo de } \\
\text { ensaio } \\
24 \mathrm{~h}\end{array}$} \\
\hline Cianetos & $<0.02$ & 1000 & $\mathrm{x}$ & -- & \\
\hline Cloretos & $\mathrm{x}$ & $-\ldots$ & $\mathrm{x}$ & - & \\
\hline Dureza & $\mathrm{x}$ & - & $\mathrm{x}$ & $\cdots$ & \\
\hline Fenóis & 15,86 & 10 & $x$ & $\ldots$ & \\
\hline Fluoretos & $x$ & $-\cdots$ & $<0,1$ & 150 & \\
\hline Vanádio & 24 & 1000 & $x$ & $\ldots$ & \\
\hline Nitratos & $x$ & $--\ldots$ & $\mathrm{x}$ & - & \\
\hline Sulfatos & $x$ & - & $x$ & - & \\
\hline Surfactantes & $\mathrm{x}$ & - & $\mathrm{x}$ & $-\cdots$ & \\
\hline Antimônio & 40 & & & & \\
\hline Cobalto & 8 & - & $\frac{x}{x}$ & $\cdots$ & \\
\hline Molibdenio & 14 & - & $x$ & - & \\
\hline
\end{tabular}

1- $\left({ }^{* *}\right)=$ Limite para o chumbo em composto orgânicos $=100 \mathrm{mg} \mathrm{Pb} / \mathrm{kg}$. e em compostos minerais $=1000 \mathrm{mg} \mathrm{Pb} / \mathrm{kg}$

2- $\mathrm{VMP}=$ Valores máximos permitidos 
Tabcla 19: Análises microbiológicas na amostra da pista de Cal -03

Laboratório Puriquima Lida

Laudo: 24/6/1998 LP-981/1-98

\begin{tabular}{|c|c|c|}
\hline \multirow{3}{*}{ Amostra } & Coliforme & Salmoncla \\
& Fecal & $\mathrm{cm}$ \\
& NMP/100g & $25 \mathrm{~g}$ \\
\hline
\end{tabular}

\begin{tabular}{|l|l|l|}
\hline 10200 & $<3$ Ausentc & Ausente \\
\hline
\end{tabular}

NMP - numcro mais prováıcl: UFC - unidade formadora de colônia.

$17^{\text {th }} \mathrm{cd}$. "STANDARD METHODS For the Examination of Water and Wastewater". APHA, AWWA. EPCF.

A torta na data da amostragem de 29/5/1998, foi considerada residuo perigoso pelo laudo do Laboratório Puriquima de 24/6/1998 (LP:918/1-98) devido à liberação de fenóis. Transcreve-se:

[...]Os seguintes parâmetros ultrapassaram os valores máximo permitidos pela Norma 10004. Massa bruta: fenóis [...] o resíduo, devido suas características obtidas nas análises fisico-químicas dos ensaios realizados conforme norma 10.004 , pode ser calssificado como:

\section{Classe I RESÍDUO SOLIDO PERIGOSO}

Disposição:

O residuo deve ser acondicionado em tambores ou caçambas fechadas e identificadas como RESIDUO SÓLIDO PERIGOSO e disposto em ATERRO INDUSTRIAL Classe I ou INCINERADO, OU RECICLADO. 
Tabela 20: Análises físico-químicas na amostra da pista ABS-01 (NBR 10.004) Umidadc: $58.24 \%$ Laboratório Puriquima Lida

Laudo: 4/6/1998 - Amostra 9842

\begin{tabular}{|c|c|c|c|c|c|}
\hline \multirow[b]{2}{*}{ Parâmctros } & \multicolumn{2}{|c|}{ Massa Bruta } & \multicolumn{2}{|c|}{ Lixiviado } & \multirow[b]{2}{*}{$\begin{array}{l}\text { Ensaio de } \\
\text { Lixiviação }\end{array}$} \\
\hline & $\begin{array}{l}\text { Resultados } \\
\mathrm{mg} / \mathrm{kg}\end{array}$ & $\begin{array}{l}\text { VMP } \\
\mathrm{mg} / \mathrm{kg}\end{array}$ & $\begin{array}{l}\text { Resultados } \\
\mathrm{mg} / \mathrm{l}\end{array}$ & $\begin{array}{l}\text { VMP } \\
\text { mg/l }\end{array}$ & \\
\hline Olcos c Graxas & $1.23 \%$ & $5 \%$ & $x$ & -- & \multirow{6}{*}{$\begin{array}{c}\mathrm{pH} \text { Inicial } \\
12,62\end{array}$} \\
\hline Aluminio & $x$ & $\cdots$ & $x$ & $\cdots$ & \\
\hline Arsçnio & $<5$ & 1000 & $<0.5$ & 5 & \\
\hline Bário & 200 & -- & 3.7 & 100 & \\
\hline Berilio & $<2$ & 100 & $\mathrm{x}$ & $\cdots$ & \\
\hline Cádmio & 3.6 & $\cdots$ & 0,04 & 0.5 & \\
\hline Chumbo & 58 & $* *$ & 0.3 & 5 & \multirow{6}{*}{$\begin{array}{c}\text { Massa da } \\
\text { Amostra } \\
50 \mathrm{~g} \\
\text { (base seca) }\end{array}$} \\
\hline Cobre & 144 & - & $x$ & -.. & \\
\hline Cromo Total & 152 & $\cdots$ & $<0,20$ & 5 & \\
\hline Cromo Hexay & 2 & 100 & $x$ & $\cdots$ & \\
\hline Manganês & $x$ & $\cdots$ & $x$ & $\cdots$ & \\
\hline Mercúrio & 0,7 & 100 & $<0,001$ & 0.1 & \\
\hline Prata & 13 & $\ldots$ & $<0,01$ & 5 & \multirow{4}{*}{$\begin{array}{c}\text { Volume HAc } \\
0,5 \mathrm{~N} \\
200 \mathrm{ml}\end{array}$} \\
\hline Selênio & $<1$ & 100 & $<0,5$ & 1 & \\
\hline Sódio & $x$ & $\ldots$ & $x$ & $\ldots$ & \\
\hline Zinco & 640 & $\cdots$ & $\mathrm{x}$ & $\cdots$ & \\
\hline Niquel & 60 & $\cdots$ & $\mathrm{x}$ & $\cdots$ & \multirow{15}{*}{$\begin{array}{c}\text { Tempo de } \\
\text { ensaio } \\
24 \mathrm{~h}\end{array}$} \\
\hline Ferro & $x$ & $\ldots$ & $\mathrm{x}$ & $\cdots$ & \\
\hline Cianetos & $<0,02$ & 1000 & $\mathrm{x}$ & $\cdots$ & \\
\hline Cloretos & $x$ & $\ldots$ & $x$ & $\cdots$ & \\
\hline Dureza & $x$ & $\cdots$ & $x$ & $\cdots$ & \\
\hline Fenóis & 9.851 & 10 & $x$ & $\ldots$ & \\
\hline Fluoretos & $x$ & $\cdots$ & $<0.1$ & 150 & \\
\hline Vanádio & 24 & 1000 & $x$ & $\cdots$ & \\
\hline Nitratos & $x$ & $\cdots$ & $\mathrm{x}$ & $\ldots$ & \\
\hline Sulfatos & $\mathrm{x}$ & $\cdots$ & $\mathrm{x}$ & $\cdots$ & \\
\hline Surfactantes & $\mathrm{x}$ & $\cdots$ & $x$ & $\cdots$ & \\
\hline & & & & & \\
\hline Antimônio & $<2$ & & & & \\
\hline Cobalto & 4 & -- & $\mathrm{x}$ & $\cdots$ & \\
\hline Molibdênio & 8 & $\cdots$ & $x$ & $\cdots$ & \\
\hline
\end{tabular}

1- $\left({ }^{* *}\right)=$ Limite para o chumbo $\mathrm{cm}$ composto orgânicos $=100 \mathrm{mg} \mathrm{Pb} / \mathrm{kg}$. e em compostos minerais $=1000 \mathrm{mg} \mathrm{Pb} / \mathrm{kg}$

2. $\mathrm{VMP}=$ Valores máximos permitidos. 
Tabcla 21: Análises microbiológicas na amostra da pista de ABS -01

Laboratório Puriquima Lida

Laudo: 29/5/1998 LP-781/2-98

\begin{tabular}{|c|c|c|c|}
\hline Amostra & $\begin{array}{c}\text { Coliforme } \\
\text { Total } \\
\text { NMP/100g }\end{array}$ & $\begin{array}{c}\text { Coliforme } \\
\text { Fecal } \\
\text { NMP/100g }\end{array}$ & $\begin{array}{c}\text { Salmonela } \\
\mathbf{c m} \\
25 \mathrm{~g}\end{array}$ \\
\hline 9842 & 110.000 & $<3$ Auscnte & Ausente \\
\hline
\end{tabular}

NMP - número mais provável: UFC - unidade formadora de colônia. $17^{\text {th }}$ ed. "STANDARD METHODS For the Examination of Water and Wastewater", APHA, AWWA, EPCF. 
Tabcla 22: Análises físico-químicas na amostra da pista ABS+Cal-01

(NBR 10.004)

Umidade: $42,53 \%$ Laboratório Puriquima Ltda

Laudo: 15/6/1998 - Amostra 10096

\begin{tabular}{|c|c|c|c|c|c|}
\hline \multirow[b]{2}{*}{ Parâmetros } & \multicolumn{2}{|c|}{ Massa Bruta } & \multicolumn{2}{|c|}{ Lixiviado } & \multirow[b]{2}{*}{$\begin{array}{l}\text { Ensaio de } \\
\text { Lixiviação }\end{array}$} \\
\hline & $\begin{array}{l}\text { Resultados } \\
\mathrm{mg} / \mathrm{kg}\end{array}$ & $\begin{array}{l}\text { VMP } \\
\mathrm{mg} / \mathrm{kg}\end{array}$ & $\begin{array}{c}\text { Resultados } \\
\mathrm{mg} / \mathrm{l}\end{array}$ & $\begin{array}{l}\text { VMP } \\
\mathrm{mg} / 1\end{array}$ & \\
\hline Óleos c Graxas & $1,04 \%$ & $5 \%$ & $x$ & - & \multirow{3}{*}{$\begin{array}{c}\mathrm{pH} \text { Inicial } \\
12,67\end{array}$} \\
\hline Aluminio & $\mathrm{x}$ & - & $x$ & - & \\
\hline Arsênio & $<5$ & 1000 & $<0,5$ & 5 & \\
\hline Bário & 580 & - & 15,9 & 100 & \multirow{3}{*}{$\begin{array}{c}\text { pH Final } \\
11,13\end{array}$} \\
\hline Berilio & $<2$ & 100 & $\mathrm{x}$ & - & \\
\hline Cádmio & 4,0 & - & $<0,02$ & 0,5 & \\
\hline Chumbo & 46 & $\star *$ & 0,60 & 5 & \multirow{6}{*}{$\begin{array}{c}\text { Massa da } \\
\text { Amostra } \\
50 \mathrm{~g} \\
\text { (base seca) }\end{array}$} \\
\hline Cobre & 154 & - & $\mathrm{x}$ & - & \\
\hline Cromo Total & 140 & - & $<0,02$ & 5 & \\
\hline Cromo Hexav. & $<1$ & 100 & $x$ & - & \\
\hline Manganês & $x$ & - & $\mathrm{x}$ & - & \\
\hline Mercúrio & $<0,1$ & 100 & $<0,001$ & 0,1 & \\
\hline Prata & 13 & - & $<0,01$ & 5 & \multirow{4}{*}{$\begin{array}{c}\text { Volume HAc } \\
0,5 \mathrm{~N} \\
200 \mathrm{ml}\end{array}$} \\
\hline Selênio & $<1$ & 100 & $<0,5$ & 1 & \\
\hline Sódio & $x$ & - & $\mathrm{x}$ & - & \\
\hline Zinco & 640 & - & $\mathrm{x}$ & - & \\
\hline Niquel & 80 & - & $\mathrm{x}$ & - & \multirow{14}{*}{$\begin{array}{c}\text { Tempo de } \\
\text { ensaio } \\
24 \mathrm{~h}\end{array}$} \\
\hline Ferro & $x$ & - & $\mathrm{x}$ & -- & \\
\hline Cianetos & 0258 & 1000 & $x$ & - & \\
\hline Cloretos & $\mathrm{x}$ & - & $\mathrm{x}$ & - & \\
\hline Dureza & $x$ & - & $\mathrm{x}$ & - & \\
\hline Fenóis & 15,43 & 10 & $x$ & - & \\
\hline Fluoretos & $\mathrm{x}$ & - & $<0,1$ & 150 & \\
\hline Vanádio & 20 & 1000 & $x$ & - & \\
\hline Nitratos & $x$ & -1 & $\mathrm{x}$ & - & \\
\hline Sulfatos & $\mathrm{x}$ & - & $\mathrm{x}$ & - & \\
\hline Surfactantes & $\mathrm{x}$ & - & $\mathrm{x}$ & - & \\
\hline Antimônio & $<2$ & & & & \\
\hline Cobalto & 4 & - & $\mathrm{x}$ & - & \\
\hline Molibdênio & 10 & -- & $\mathrm{x}$ & $\cdots$ & \\
\hline
\end{tabular}

1- $\left({ }^{* *}\right)=$ Limite para o chumbo em composto orgânicos $=100 \mathrm{mg} \mathrm{Pb} / \mathrm{kg}$. e em compostos minerais $=1000 \mathrm{mg} \mathrm{Pb} / \mathrm{kg}$

2- $\mathrm{VMP}=$ Valores máximos permitidos 
Tabcla 23: Análises microbiológicas na amostra da pista de ABS + Cal -01 Laboratório Puriquima Lida

Laudo: 15/6/1998 LP-867/2-98

\begin{tabular}{|c|c|c|c|}
\hline Amostra & $\begin{array}{c}\text { Coliforme } \\
\text { Total } \\
\text { NMP/100g }\end{array}$ & $\begin{array}{c}\text { Coliforme } \\
\text { Fecal } \\
\text { NMP/100g }\end{array}$ & $\begin{array}{c}\text { Salmonela } \\
\mathrm{cm} \\
25 \mathrm{~g}\end{array}$ \\
\hline & & \\
\hline & $<3$ Ausente & $<3$ Ausentc & Ausente \\
\hline
\end{tabular}

NMP - número mais provável: UFC - unidade formadora de colônia. $17^{\text {th }} \mathrm{cd}$. "STANDARD METHODS For the Examination of Water and Wastewater", APHA, AWWA, EPCF.

A torta na data da amostragem de 27/5/1998, foi considerada residuo perigoso pelo laudo do Laboratório Puriquima de 6/6/1998 (LP: 867/2-98) devido à liberação de fenóis. Transcreve-se:

[...]o resíduo não atende os limites impostos pela norma 10.004 , na massa bruta com relação ao parâmetro fenol

Classificação:

$O$ residuo devido suas características obtidas nas análises físico-químicos dos ensaios realizados conforme a norma NBR 10.004 pode ser classificado como Classe I - residuo sólido perigoso"

Disposição:

O residuo deve ser acondicionado em tambores ou caçambas fechadas e identificadas como RESÍDUO SÓLIDO PERIGOSO e disposto em ATERRO INDISTRIAL Classe I ou INCINERADO, OU RECICLADO. 
Tabela 24: Análises físico-químicas na amostra da pista ABS + Cal-02

(NBR 10.004)

Umidade: $58,08 \%$ Laboratório Puriquima Ltda

Laudo: 24/6/1998 - Amostra 10201

\begin{tabular}{|c|c|c|c|c|c|}
\hline \multirow[b]{2}{*}{ Parâmetros } & \multicolumn{2}{|c|}{ Massa Bruta } & \multicolumn{2}{|c|}{ Lixiviado } & \multirow[b]{2}{*}{$\begin{array}{l}\text { Ensaio dc } \\
\text { Lixiviação }\end{array}$} \\
\hline & $\begin{array}{c}\text { Resultados } \\
\mathrm{mg} / \mathrm{kg}\end{array}$ & $\begin{array}{l}\mathrm{VMP} \\
\mathrm{mg} / \mathrm{kg}\end{array}$ & $\begin{array}{c}\text { Resultados } \\
\mathrm{mg} / 1\end{array}$ & $\begin{array}{l}\text { VMP } \\
\mathrm{mg} / \mathrm{I}\end{array}$ & \\
\hline Ólcos e Graxas & $1,07 \%$ & $5 \%$ & $\mathrm{x}$ & - & \multirow{3}{*}{$\begin{array}{c}\mathrm{pH} \text { Inicial } \\
12,91\end{array}$} \\
\hline Alumínio & $x$ & - & $x$ & $\cdots$ & \\
\hline Arsênio & $<5$ & 1000 & $<0,5$ & 5 & \\
\hline Báno & 220 & - & 10,0 & 100 & \multirow{3}{*}{$\begin{array}{c}\text { pH Final } \\
12,97\end{array}$} \\
\hline Berilio & $<2$ & 100 & $\mathrm{x}$ & - & \\
\hline Cádmio & 3,6 & - & $<0,02$ & 0,05 & \\
\hline Chumbo & 130 & - & $<0.05$ & 5 & \multirow{6}{*}{$\begin{array}{l}\text { Massa da } \\
\text { Amostra } \\
50 \mathrm{~g} \\
\text { (base seca) }\end{array}$} \\
\hline Cobre & 142 & - & $\mathrm{x}$ & - & \\
\hline Cromo Total & 150 & - & $<0,02$ & 5 & \\
\hline Cromo Hexav. & 2 & 100 & $\mathrm{x}$ & - & \\
\hline Manganês & $\mathrm{x}$ & - & $\mathrm{x}$ & $\cdots$ & \\
\hline Mercúro & 0,3 & 100 & $<0,001$ & 0,1 & \\
\hline Prata & 14 & - & $<0,01$ & 5 & \multirow{5}{*}{$\begin{array}{c}\text { Volume HAc } \\
0,5 \mathrm{~N} \\
200 \mathrm{ml}\end{array}$} \\
\hline Selênio & $<1$ & 100 & $<0,5$ & 1 & \\
\hline Sódio & $x$ & $-\ldots$ & $x$ & - & \\
\hline Zinco & 600 & $-\ldots$ & $\mathrm{x}$ & - & \\
\hline Niquel & 64 & - & $x$ & - & \\
\hline Ferro & $\mathrm{x}$ & - & $x$ & - & \multirow{13}{*}{$\begin{array}{c}\text { Tempo de } \\
\text { ensaio } \\
24 \mathrm{~h}\end{array}$} \\
\hline Cianetos & 0,116 & 1000 & $x$ & - & \\
\hline Cloretos & $\mathrm{x}$ & - & $x$ & -- & \\
\hline Dureza & $\mathrm{x}$ & - & $\mathrm{x}$ & - & \\
\hline Fenóis & 6,324 & 10 & $\mathrm{x}$ & -- & \\
\hline Fluoretos & $\mathrm{x}$ & - & $<0,1$ & 150 & \\
\hline Vanádio & 12 & 1000 & $x$ & - & \\
\hline Nitratos & $\mathrm{x}$ & - & $x$ & -- & \\
\hline Sulfatos & $\mathrm{x}$ & - & $\mathrm{x}$ & - & \\
\hline Surfactantes & $\mathrm{x}$ & $\cdots$ & $\mathrm{x}$ & - & \\
\hline Antimônio & 40 & & & & \\
\hline Cobalto & 6 & - & $\mathrm{x}$ & - & \\
\hline Molibdênio & 10 & - & $\mathrm{x}$ & - & \\
\hline
\end{tabular}

1- $\left({ }^{* *}\right)=$ Limite para o chumbo $\mathrm{cm}$ composto orgânicos $=100 \mathrm{mg} \mathrm{Pb} / \mathrm{kg}$. e em compostos minerais $=1000 \mathrm{mg} \mathrm{Pb} / \mathrm{kg}$

2- $\mathrm{VMP}=$ Valores máximos permitidos. 
Tabela 25: Análises microbiológicas na amostra da pista de ABS + Cal-02 Laboratório Puriquima Ltda

Laudo: 24/6/1998 LP-918/2-98

\begin{tabular}{|c|c|c|} 
Amostra & $\begin{array}{c}\text { Coliforme } \\
\text { Fecal } \\
\text { NMP/100g }\end{array}$ & $\begin{array}{c}\text { Salmonela } \\
\mathrm{cm} \\
25 \mathrm{~g}\end{array}$ \\
\hline & & \\
\hline 10201 & $<3$ Ausente & Ausente \\
\hline
\end{tabular}

NMP - número mais provável: UFC - unidade formadora de colônia. $17^{\text {th }} \mathrm{cd}$. "STANDARD METHODS For the Examination of Water and Wastewater", APHA, AWWA, EPCF. 


\subsubsection{Construção das pistas experimentais com as tortas de filtro-prensa précondicionadas com cal e cloreto férrico}

Como indicado no item 4.1.3, as dosagens de 7\% de Absorsol para as pistas ABS a partir das 100 toneladas de torta da pilha $\mathrm{E}$ e de $17,5 \%$ de cal para as pistas $\mathrm{CAL}$ a partir das $100 \mathrm{t}$ da pilha $\mathrm{F}$ foram feitas com auxilio do misturador ilustrado nas fotos 7 a 9 daquele item.

As fotos das Figuras 16 a 18 mostram detalhes da descarga da torta já misturada ao Absorsol ou a cal, no momento da saida do equipamento misturador de aditivos no lodo.

Nas Figuras 19, 21 e 23 pode ser notado o desprendimento de amônia no lodo descarregado. Como já mencionado no item 3.1, o gás de amônia pode ser sufocante e de extrema irritação aos olhos, garganta e trato respiratório, podendo ocorrer desde suaves irritações a severas lesões devido a sua ação cáustica alcalina. Exposições a altas concentrações - a partir de $2500 \mathrm{ppm}$ por um período de $30 \mathrm{~min}$. - podem ser fatais. (Total Quimica, 2001).

A Figura 20 mostra como a adição de $17,5 \%$ de cal acelera a secagem do lodo, comparando a coloração de duas pilhas, antes e após o acréscimo do aditivo.

As Figuras 21 e 22 mostram o inicio do espalhamento das tortas para formar as pistas e as duas pistas já concluídas, uma tendo recebido Absorsol e a outra cal.

A Figura 23 torna a mostrar o desprendimento da amônia quando da construção da pista com $17,5 \%$ de cal virgem adicional na torta. 


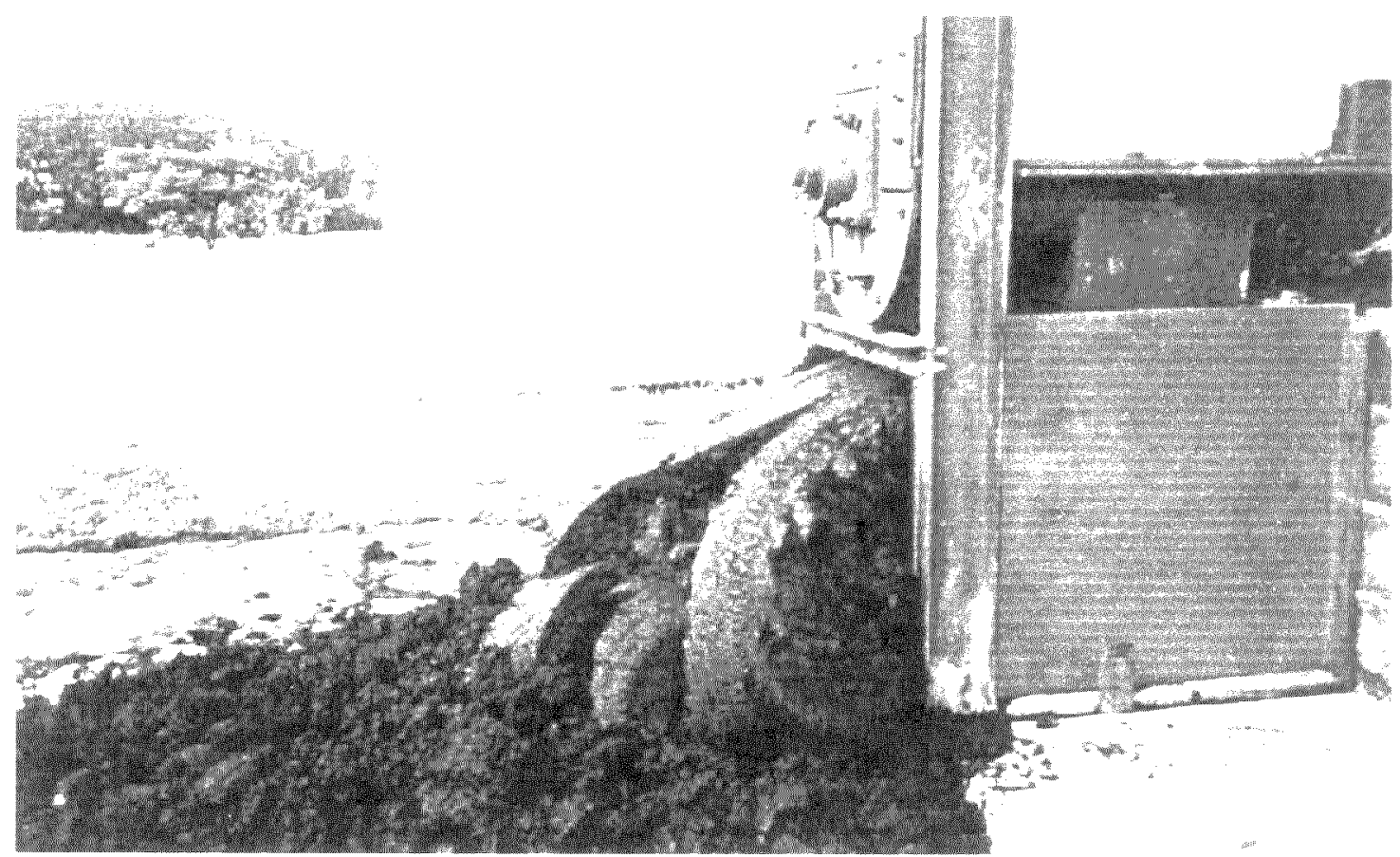

Figura 16 Descarga da torta mais Absorsol do misturador especial

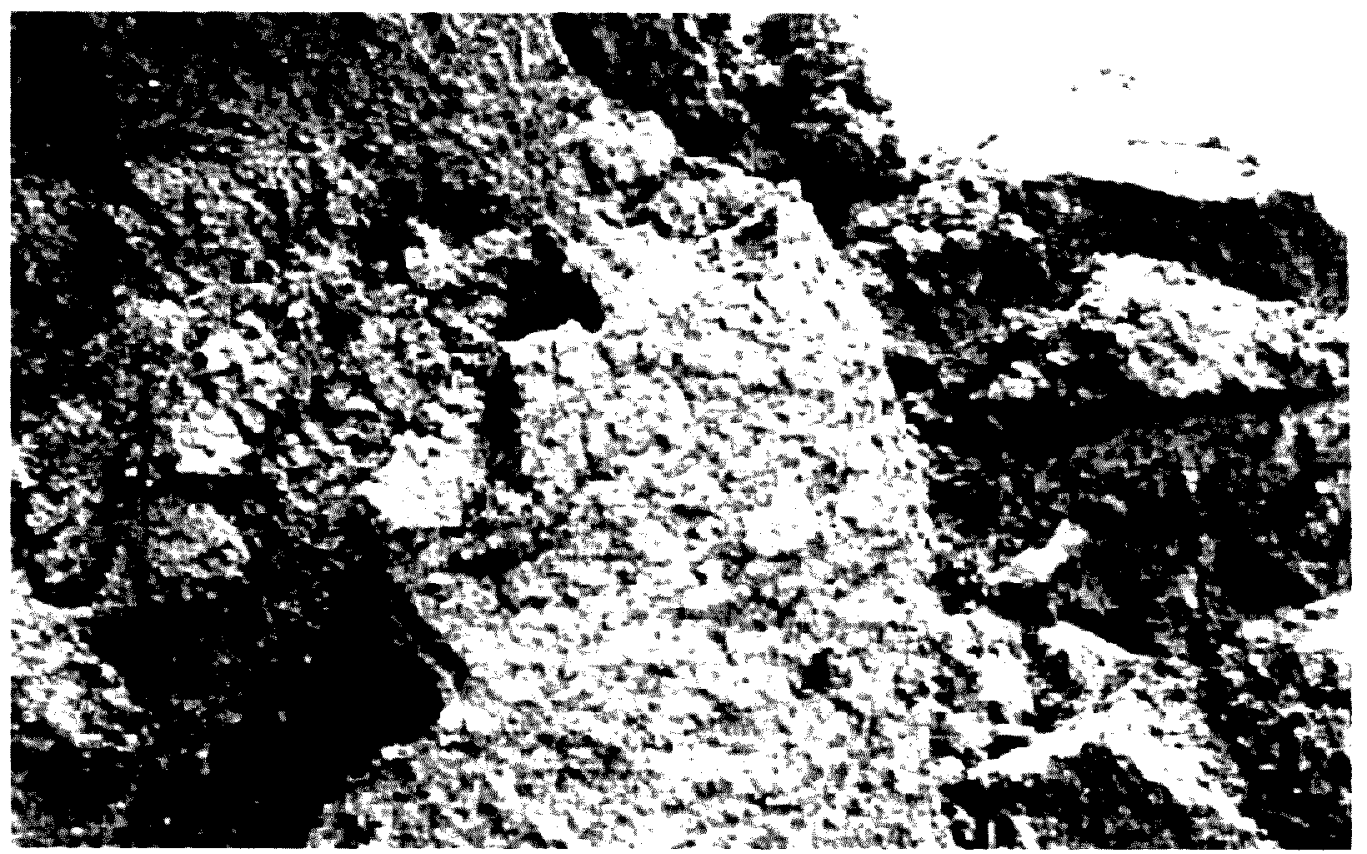

Figura 17 Aspecto da torta misturada com o aditivo mineral logo após a descarga do misturador 


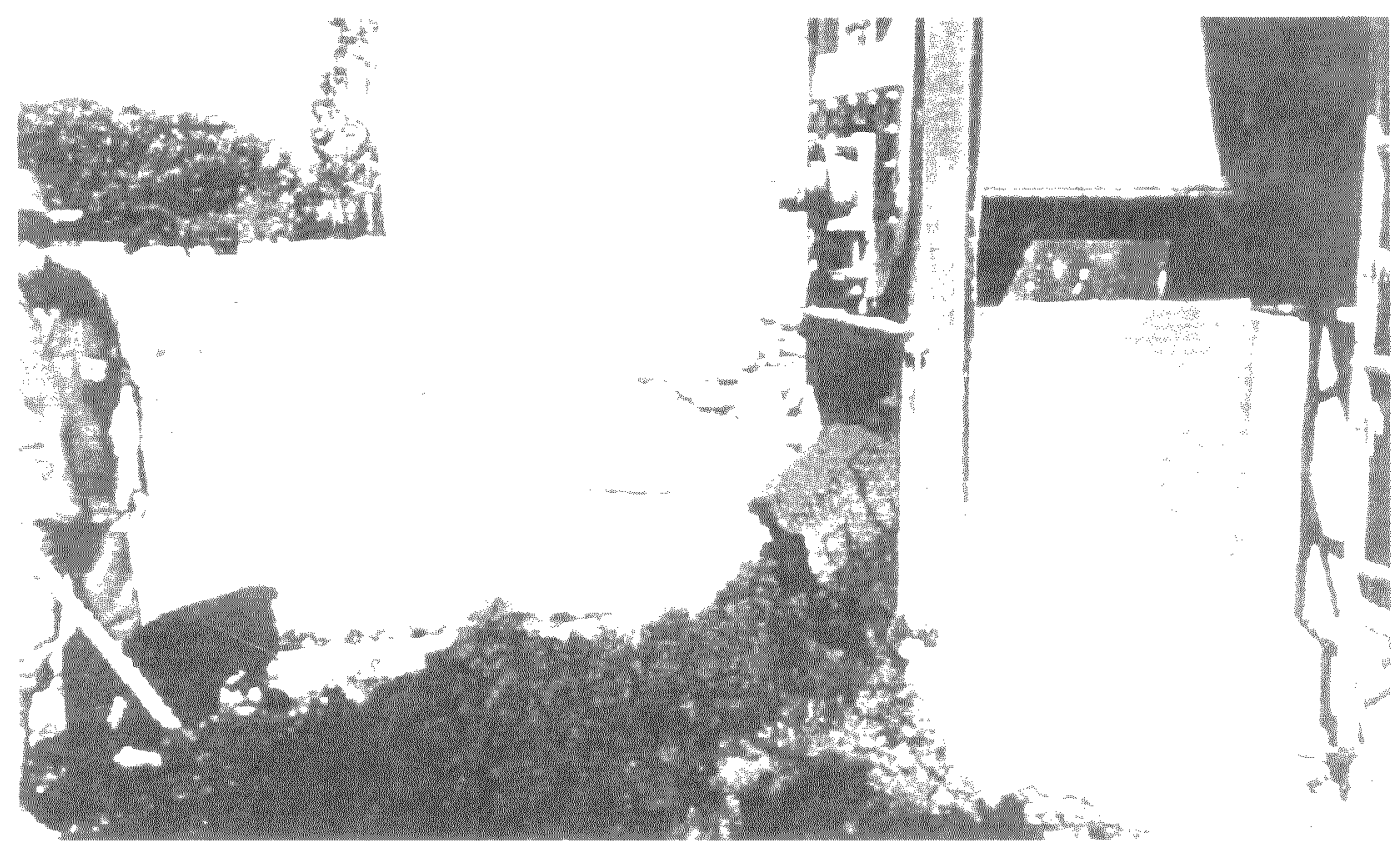

Figura 18: Descarga da torta misturada com $17,5 \%$ de cal no misturador.

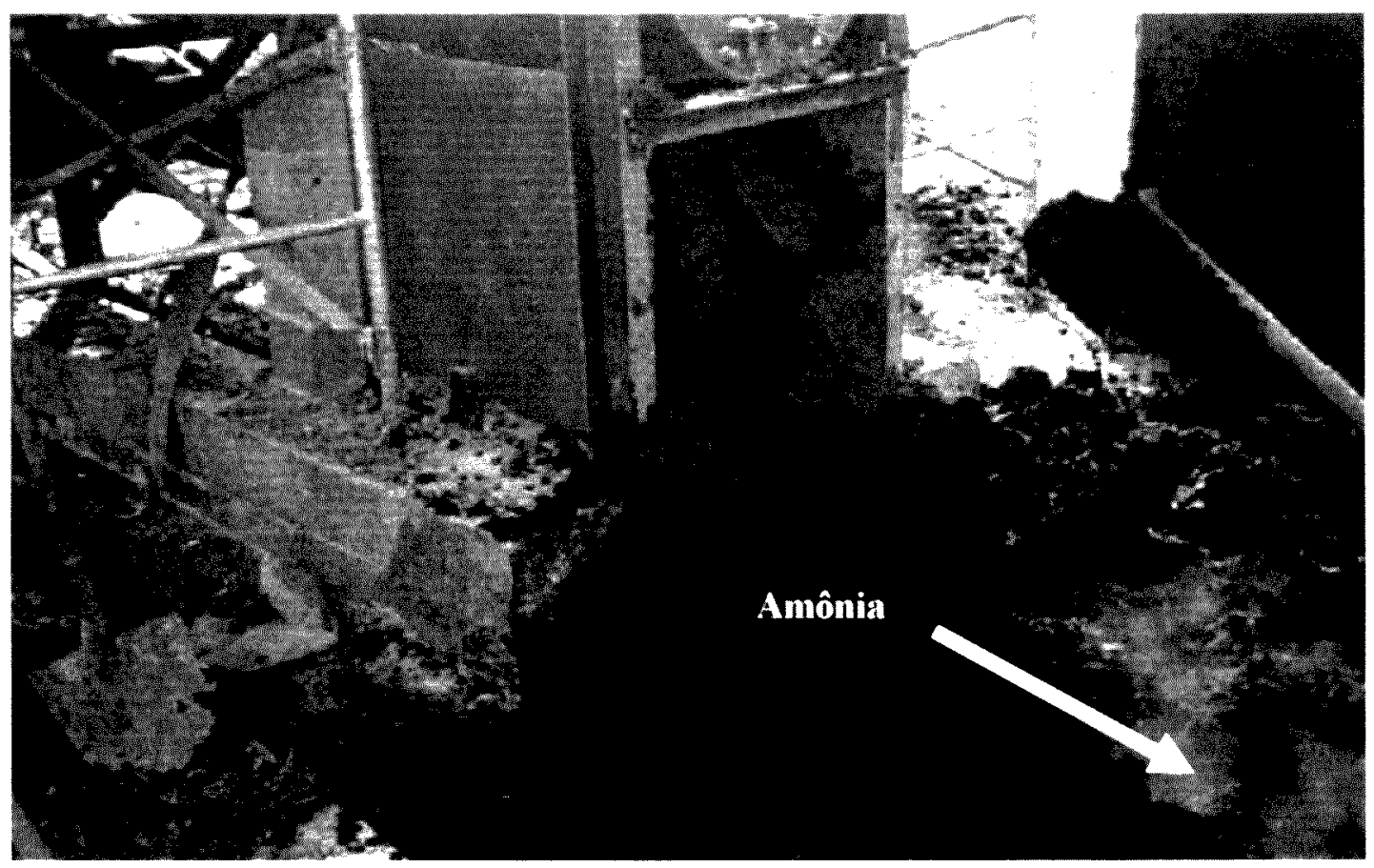

Figura 19: Lodo com 17,5\% de cal virgem notando-se desprendimento de amônia onde indicado, após cerca de 15 minutos da mistura. 


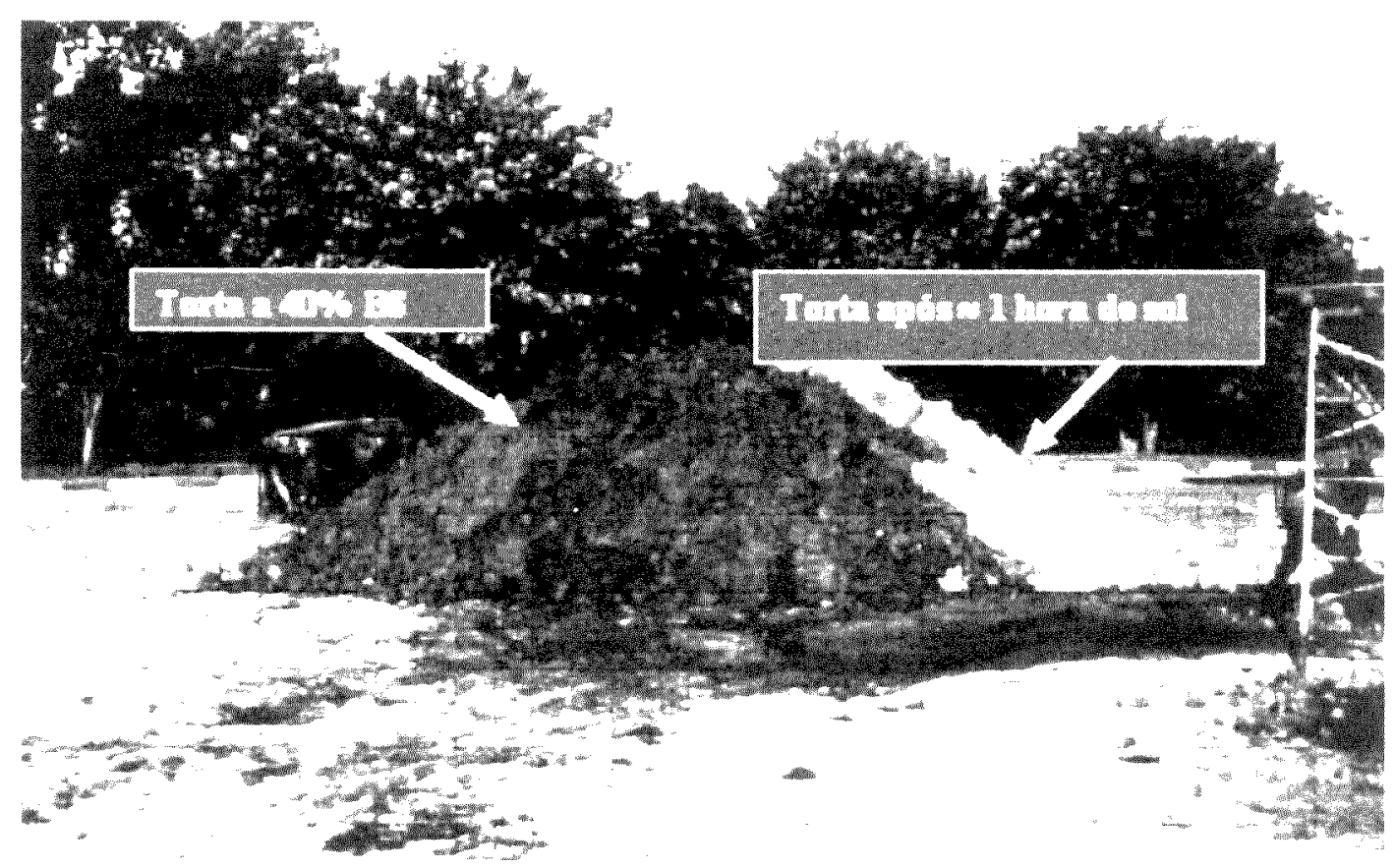

Figura 20: Mistura com $17,5 \%$ de cal. Notar, pela diferença de coloração, a rápida secagem (cerca de 1 hora)

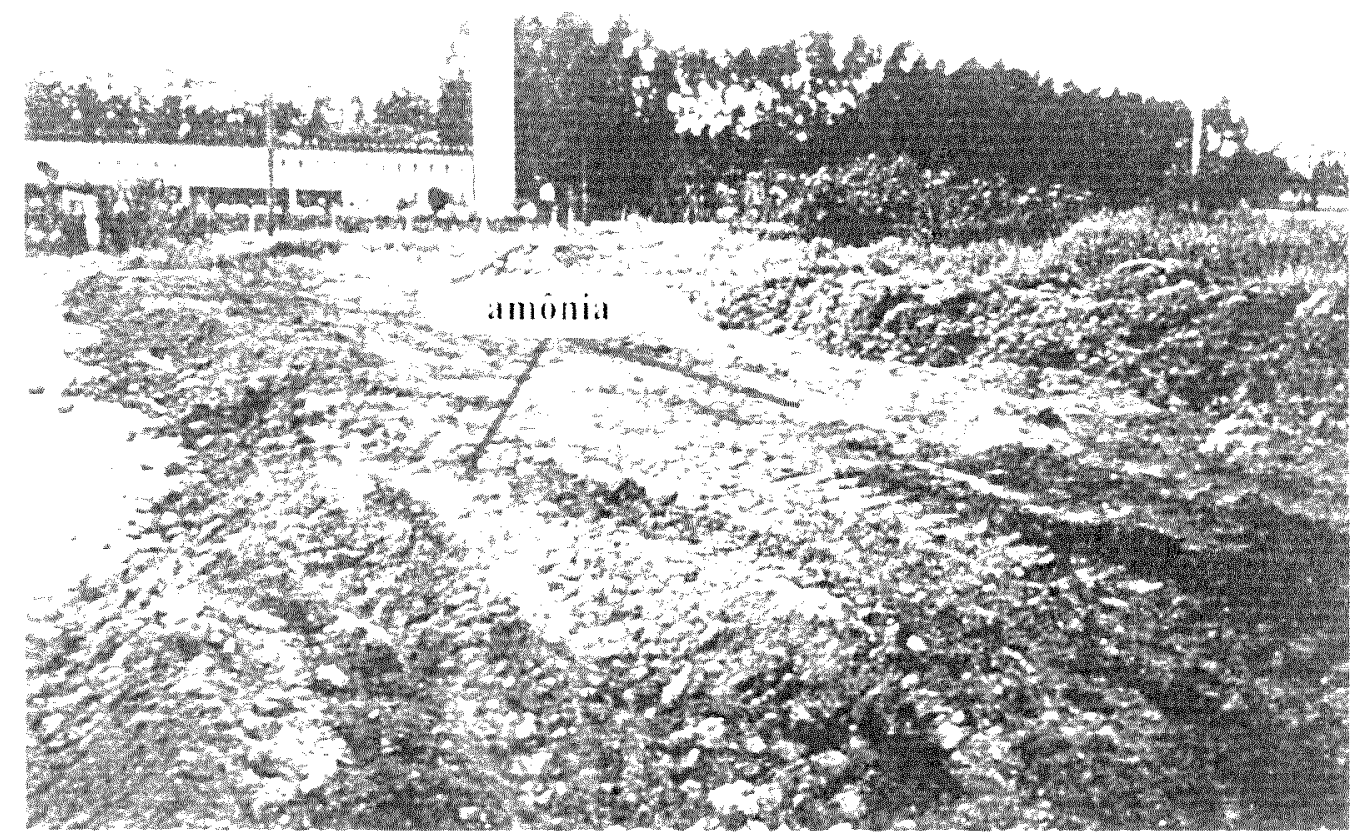

Figura 21: Espalhamento do lodo no inicio de construção das pistas 


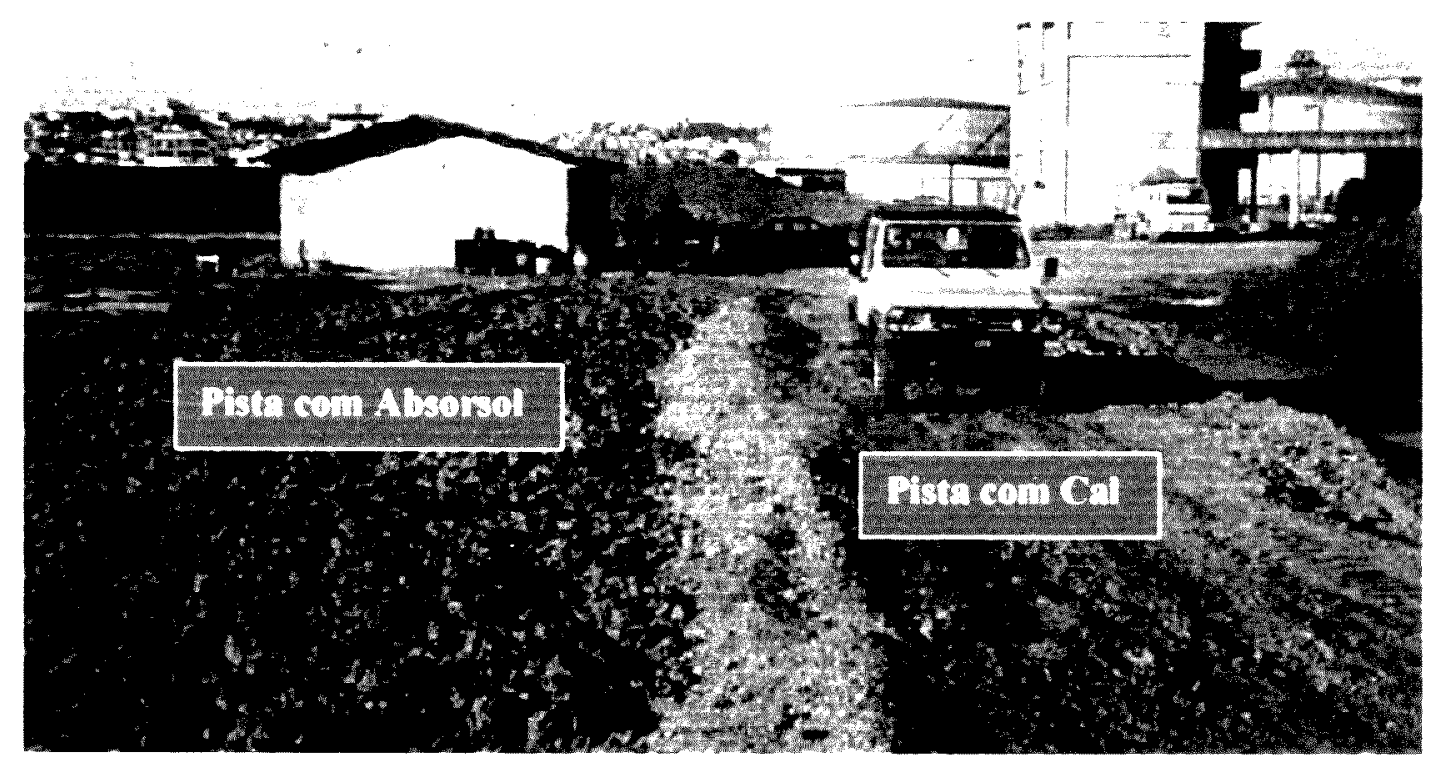

Figura 22: Aspecto das pistas construidas com as pilhas E e F, respectivamente à esquerda e a direita da foto.

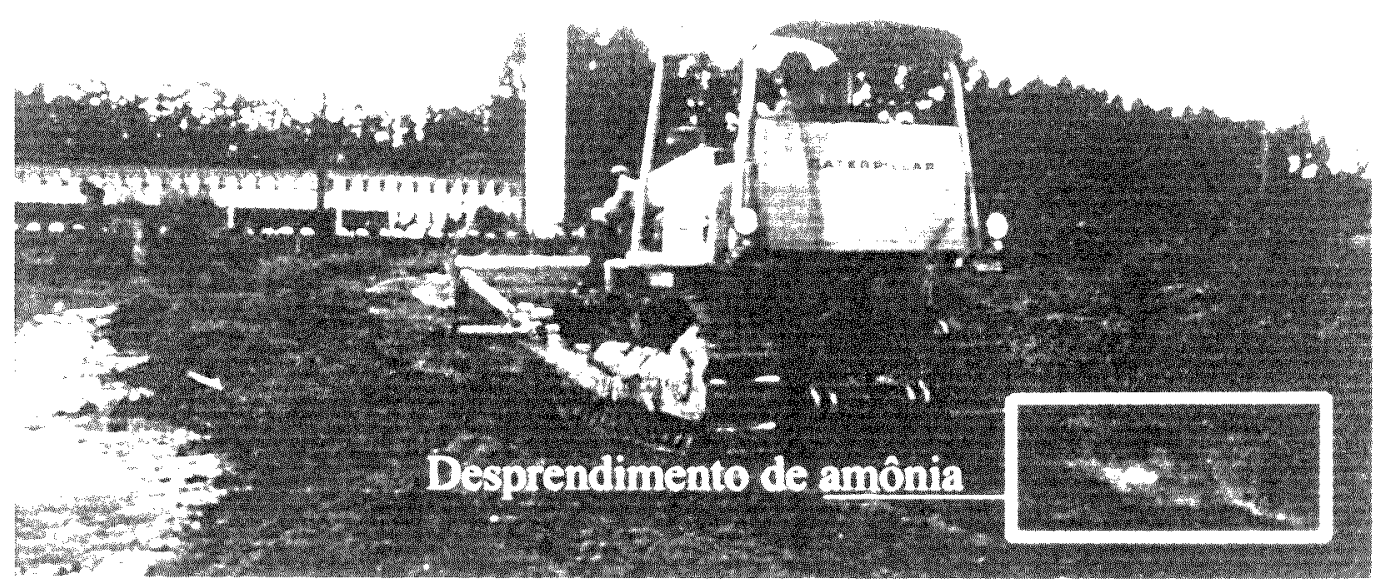

Figura 23: Pista experimental com torta de filtro prensa e $17,5 \%$ de cal virgem notando-se desprendimento de amônia após passagem do trator de esteira D-4. 


\subsubsection{Estudos geotécnicos nas pistas feitas a partir das tortas de lodo précondicionadas com cal e cloreto férrico}

O principal objetivo dos estudos geotécnicos foi o de obter uma avaliação do comportamento mecânico da torta de filtro-prensa após diversos condicionamentos, visando sua disposição e compactação em camadas sucessivas e sobrepostas, ou seja, na construção de aterro exclusivo previsto no plano diretor de lodos.

A partir de amostras retiradas das pistas foram realizados ensaios de resistência à compressão simples (CS), Índice de Suporte Califómia (ISC) e percentual de massa seca (MS) representando-se graficamente os resultados que forem obtidos.

As pistas foram compactadas com sapo mecânico e um mês após o lançamento suportavam o tráfego de veiculos sem deformação. Uma pequena deformação durante o lançamento foi interpretada como uma compactação desejável durante a construção, e tida como aceitável visto que não foi exagerada.

\subsubsection{Ensaios de resistência à compressão simples}

As amostras para o ensaio de compressão simples foram retiradas antes do espalhamento do lodo pelo trator, escavando-se as tortas descarregadas para preenchimento dos cilindros como indicam as Figuras 24 e 25. 


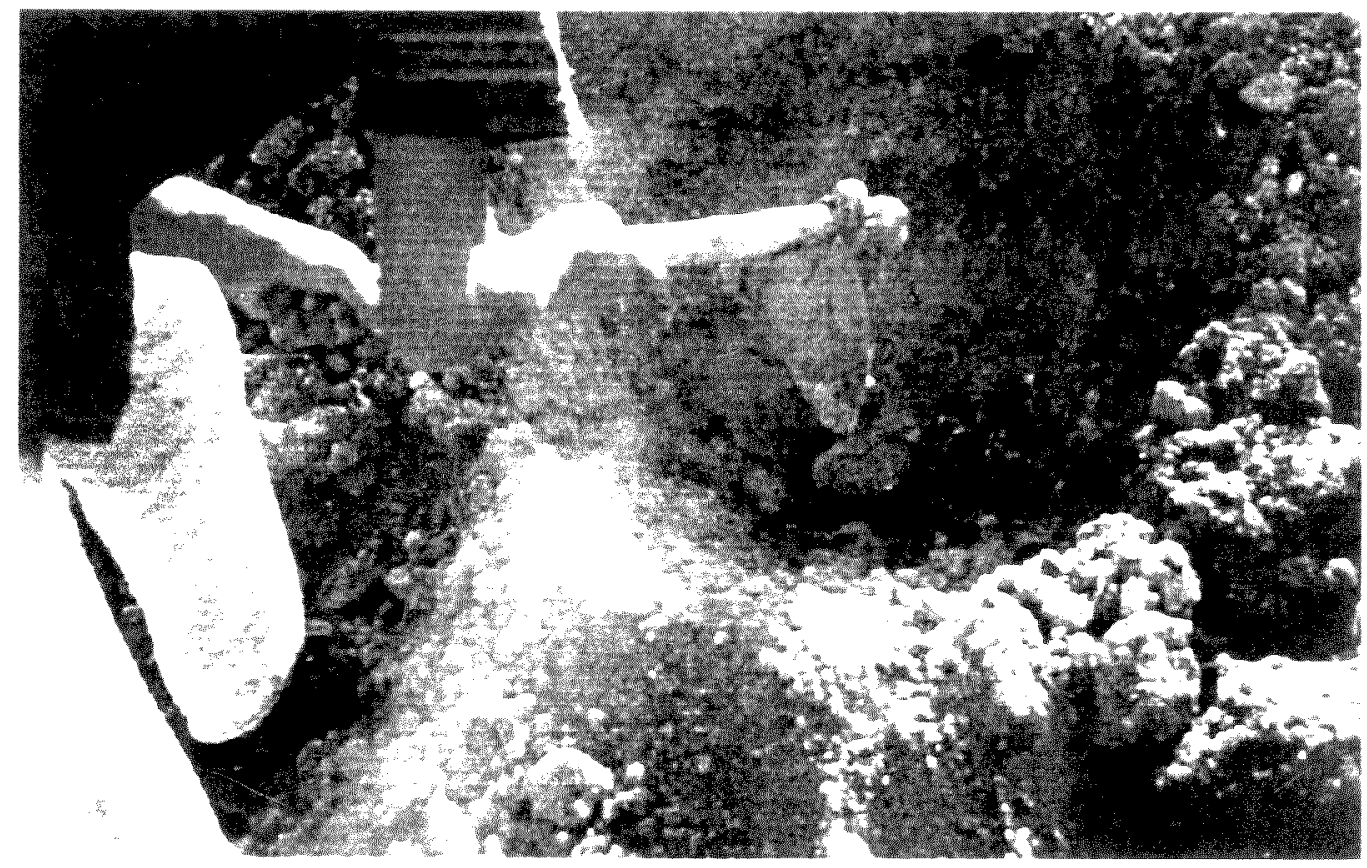

Figura 24: Retirada de amostra para ensaio de compressão simples antes do espalhamento da pista lodo $+17,5 \%$ de cal (temperatura $\pm 80^{\circ} \mathrm{C}$ )

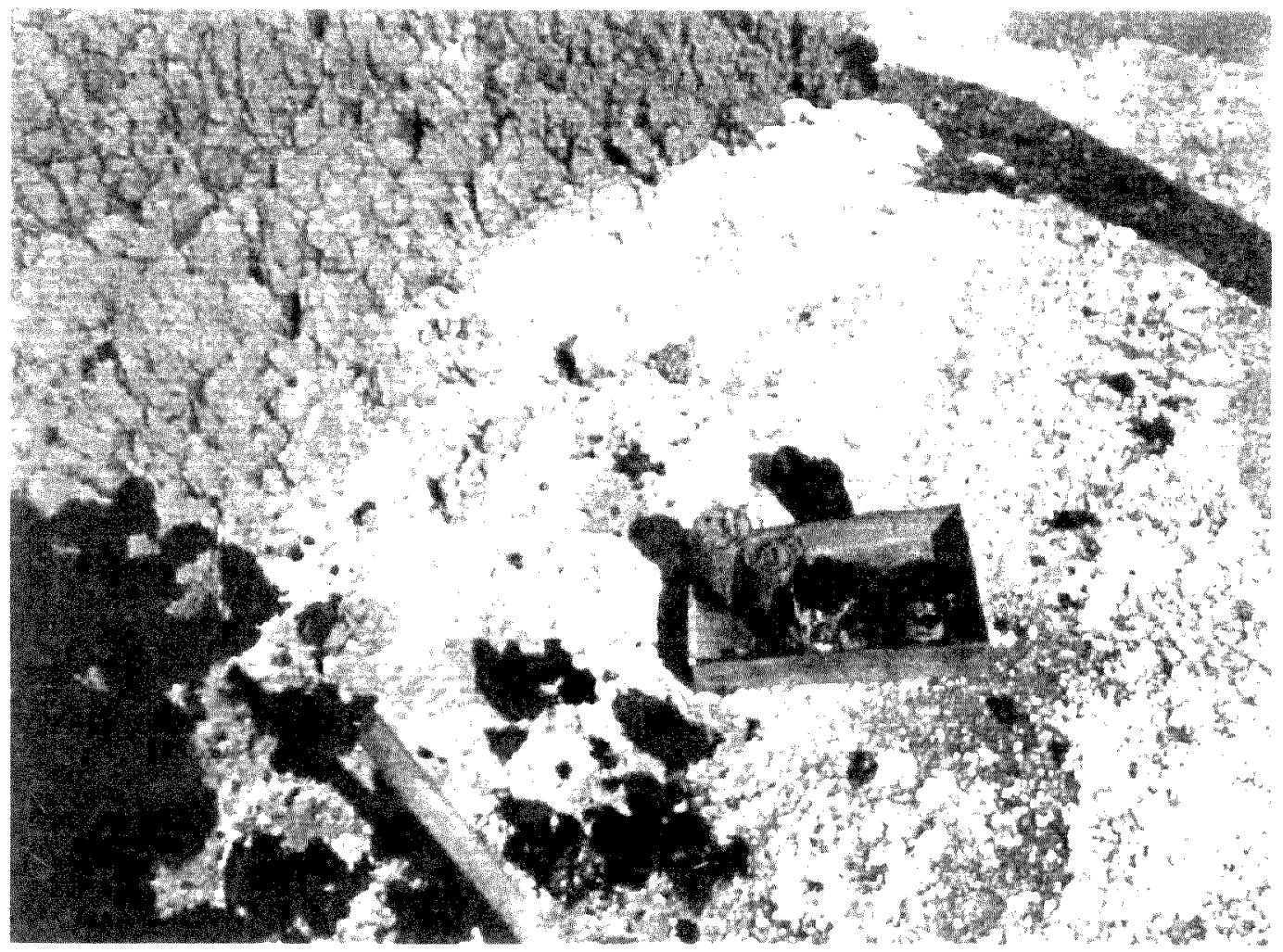

Figura 25: Cilindros para envio ao laboratório de solos 
A Figura 26 mostra como variou a resistência a compressão simples no intervalo de 0 a 40 dias para as quatro pistas experimentais construídas.

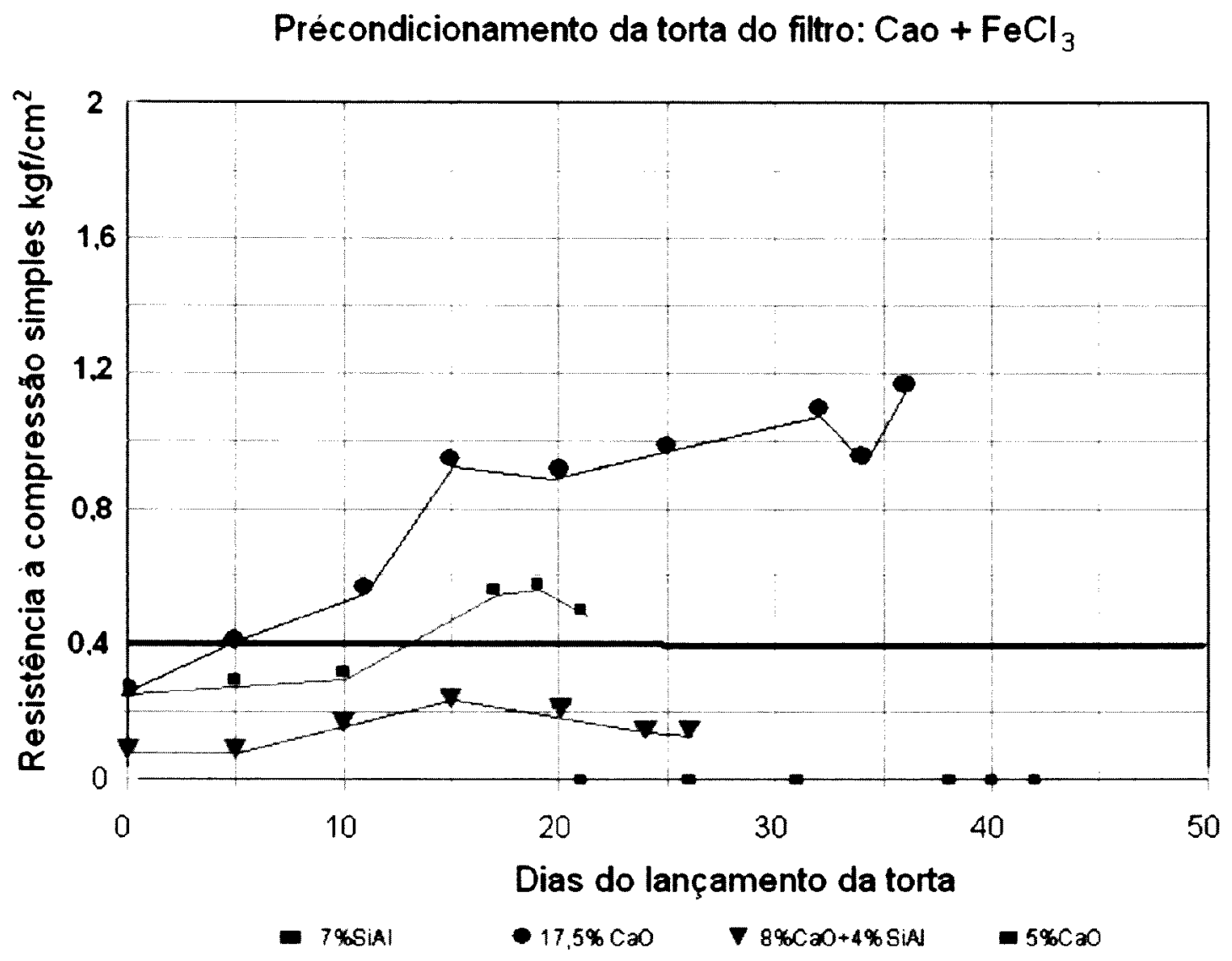

Figura 26: Variação da resistência à compressão simples de 0 a 40 dias

Fonte: Adaptado de Alphageos, 1998

Durante o período de recompactação seguido de amostragem geotécnica, os resultados mais favoráveis de resistência à compressão simples foram obtidos na pista construída com a mistura da torta precondicionada com cal que recebeu $17,5 \%$ de cal adicional. Usando-se Absorsol como único aditivo os resultados de resistência à compressão simples foram nulos, mesmo após 40 dias da recompactação da pista. 


\subsubsection{Ensaios de determinação do Índice Suporte Califórnia}

As Figuras 27 e 28 mostram como foi feita a coleta de amostra para o Ensaio do Índice Suporte Califómia após espalhamento pelo D-4, seguindo as recomendações da NBR 9.895 de 1.987 , para as pistas construidas com as quatro dosagens e aditivos já mencionados. 


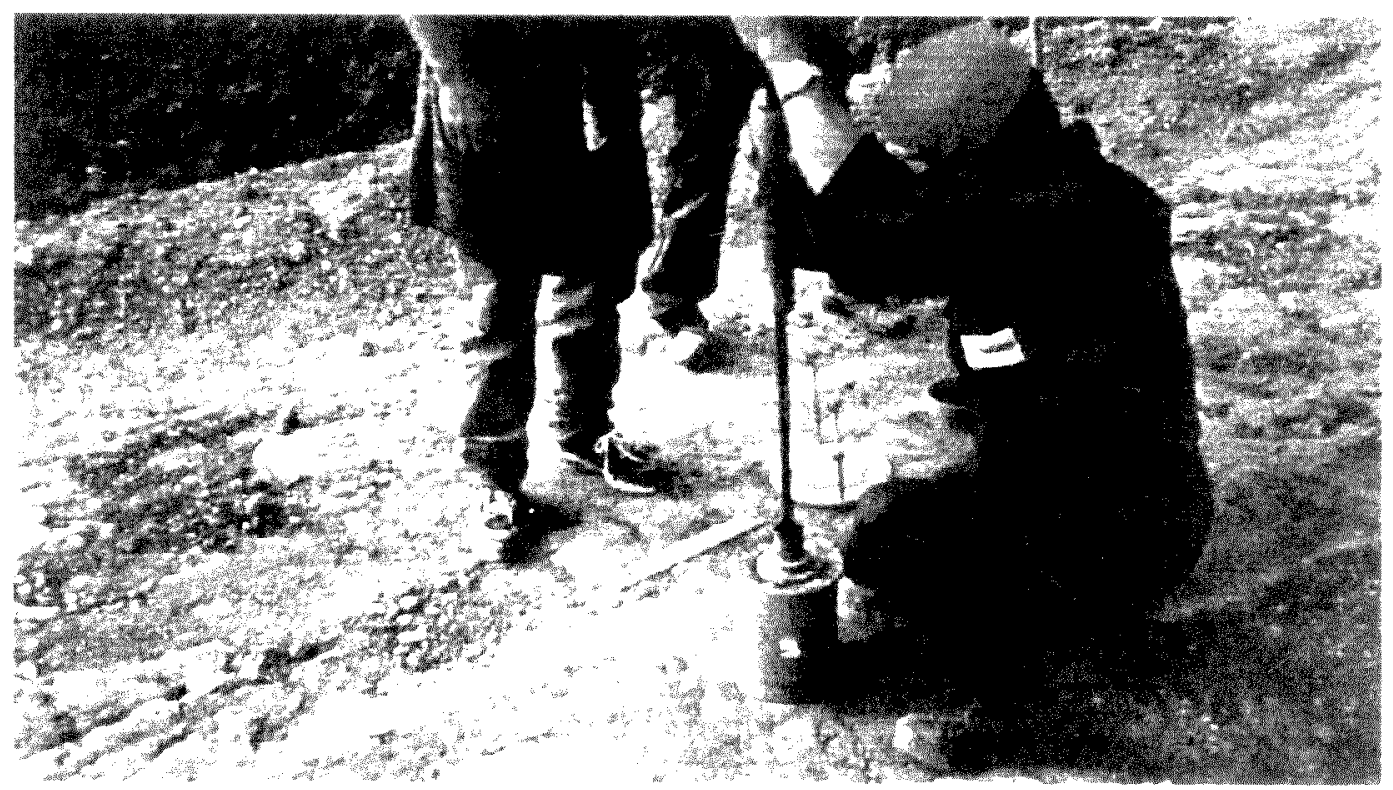

Figura 27: Coleta de amostra da pista com 17,5\% de cal, após espalhamento da torta pelo $\mathrm{D}-4$, para o ensaio de ISC.

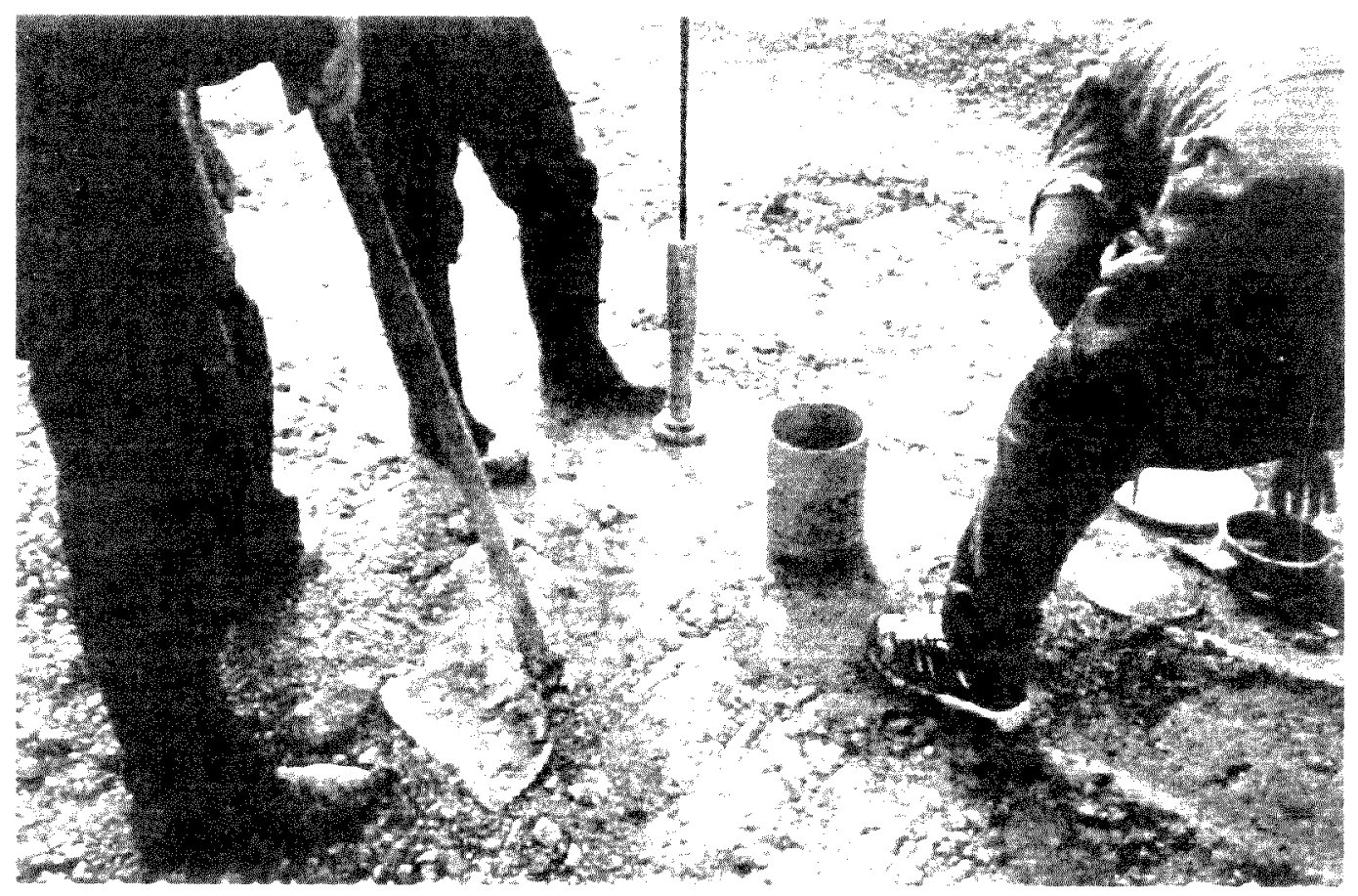

Figura 28: Coleta de amostra para o ensaio de ISC 
A Figura 29 mostra, desde de 0 até 40 dias, como variou o índice suporte Califórnia nas quatro pistas

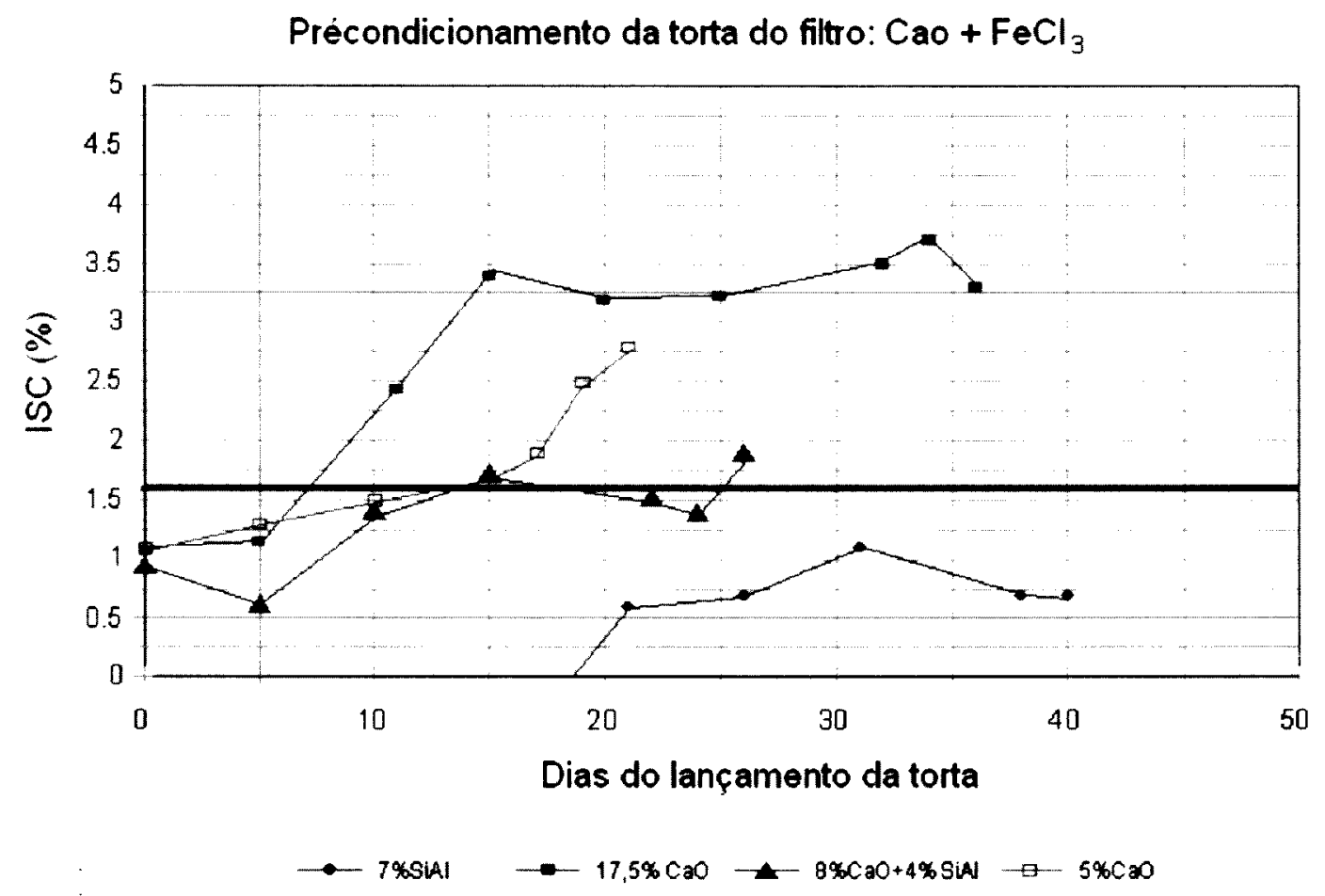

Figura 29: Variação do ISC de 0 a 40 dias

Fonte: Adaptado de Alphageos, 1998

Os ISC obtidos mostram que os melhores resultados foram os da pista construída com $17,5 \%$ de cal, uma vez que conseguiram resultados aceitáveis após 7 dias da construção. Mostram também que resultados aceitáveis poderiam ser conseguidos a um custo menor com sacrificio do prazo, usando-se apenas $5 \%$ de cal ou $8 \%$ de cal e $4 \%$ de Absorsol, ambos oferecendo resultados aceitáveis após cerca de 17 dias e tendência de resultados cada vez mais favoráveis em prazos maiores, para a primeira mistura de forma continua e para a segunda, ISC maiores após 23 dias. O uso exclusivo do Absorsol não ofereceu resultados favoráveis. 
A Figura 30 mostra o acompanhamento da umidade das pistas, de 0 a 40 dias.

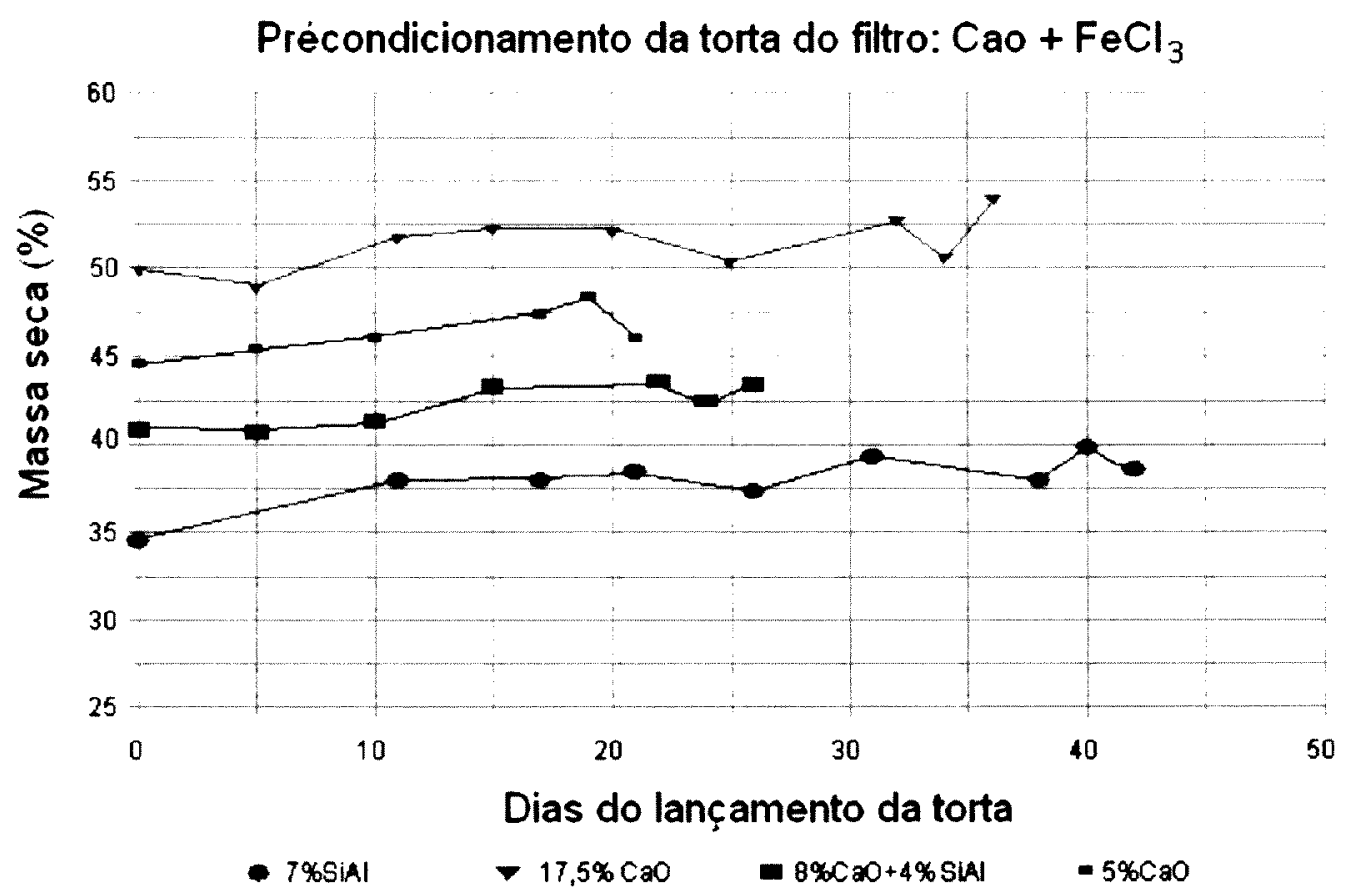

Figura 30: Variação da massa seca da torta nas pistas, de 0 a 40 dias. Fonte: Adaptado de Alphageos, 1998

Como se observa pela evolução da umidade, a pista que recebeu exclusivamente Absorsol obteve um acréscimo de 5 pontos na concentração de sólidos aos 10 dias, e as demais, com ou sem Absorsol, aos 15 dias. Após 35 dias observou-se um aumento de 7 pontos na concentração de sólidos da pista construída usando apenas Absorsol e de 5 pontos na que recebera $17,5 \%$ de cal. 


\subsubsection{Resistência ao tráfego de veículos}

A futura situação de resistência ao tráfego durante a construção foi simulada pela passagem de veículos e de um trator de esteiras $D-4$ sobre as pistas experimentais.

As pistas foram compactadas com sapo mecânico seis dias após o lançamento das várias misturas de lodo com condicionantes, antes e depois do espalhamento com o trator.

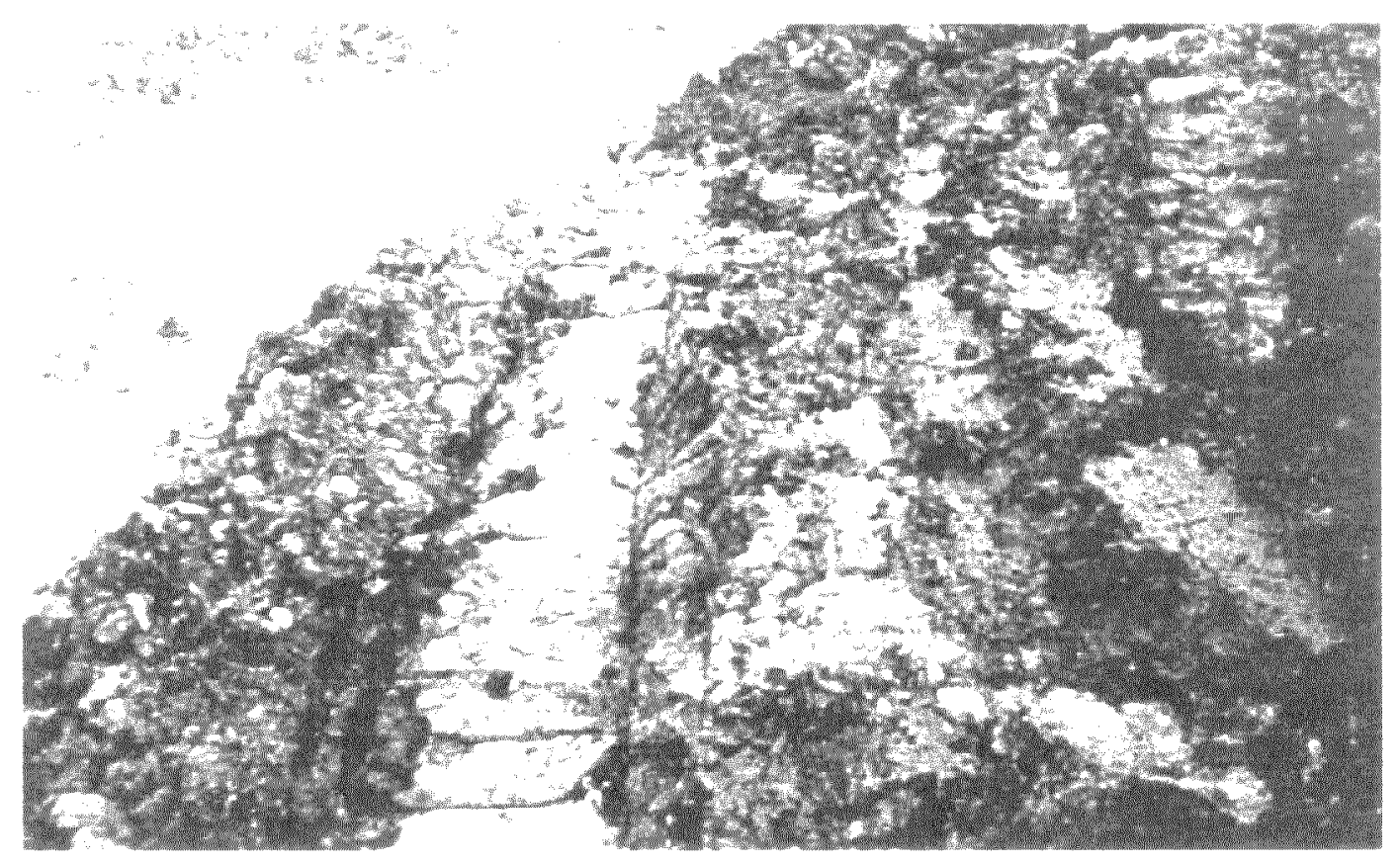

Figura 31: Pista com 7\% de Absorsol mostrando baixa resistência ao tráfego da esteira de um trator $\mathrm{D}-4$. 


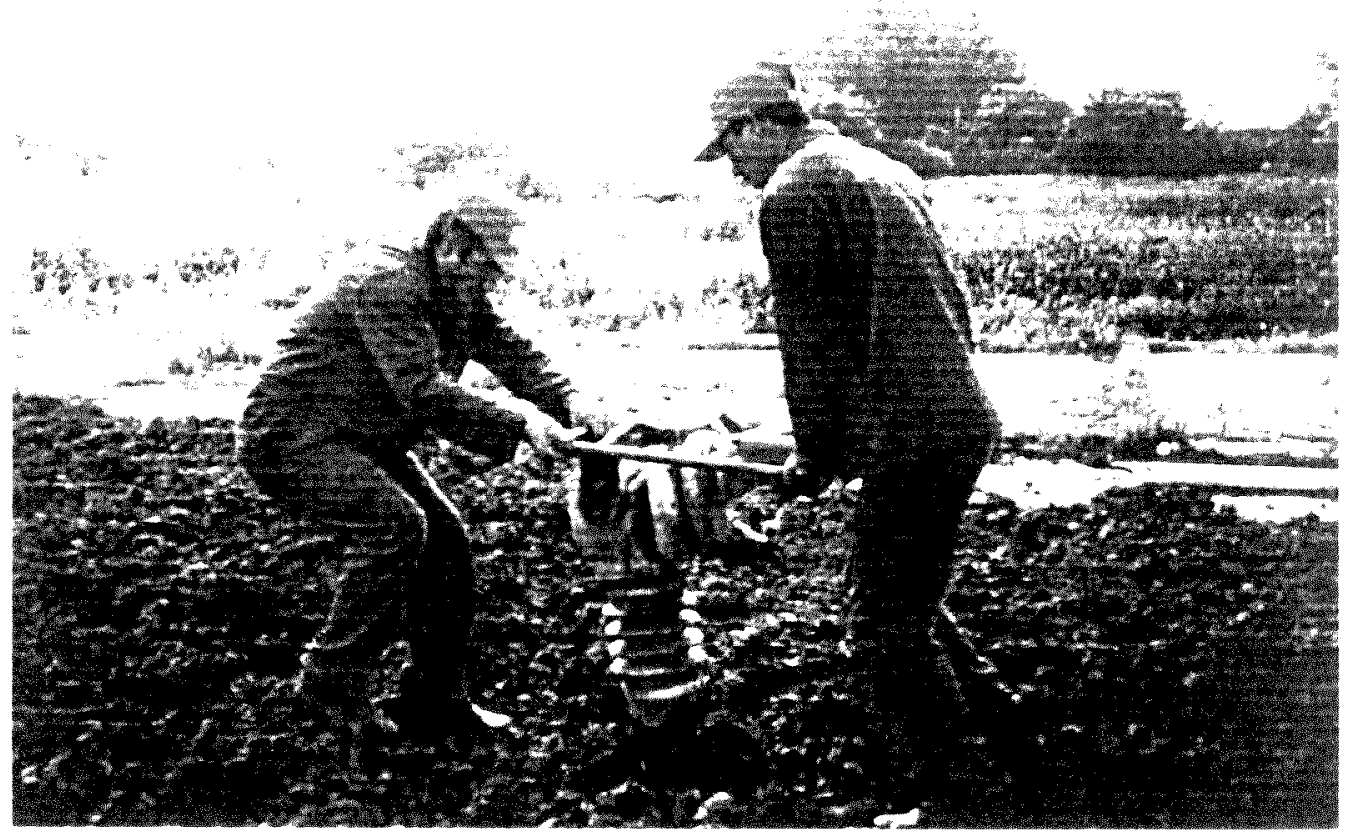

Figura 32: Tentativa de compactação da pista com $7 \%$ de Absorsol

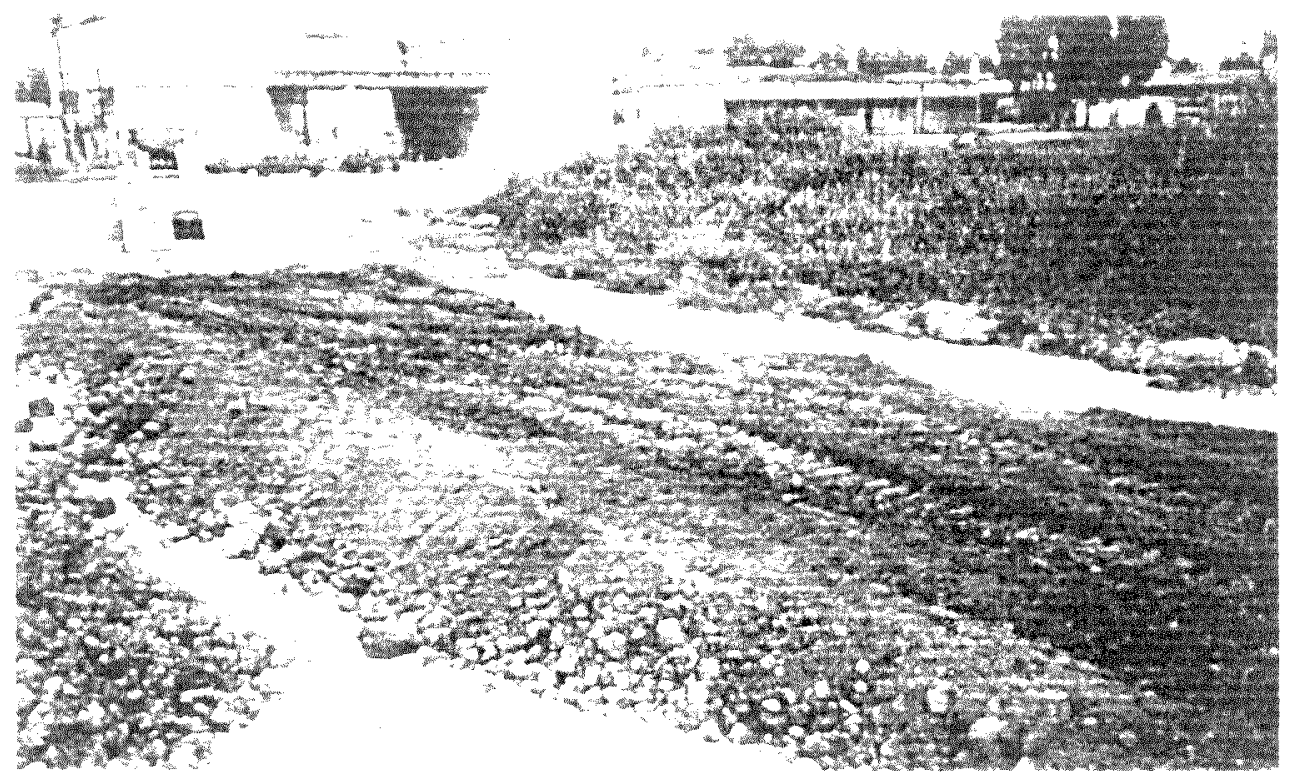

Figura 33: Pista com $17,5 \%$ de cal virgem após espalhamento e compactação. 


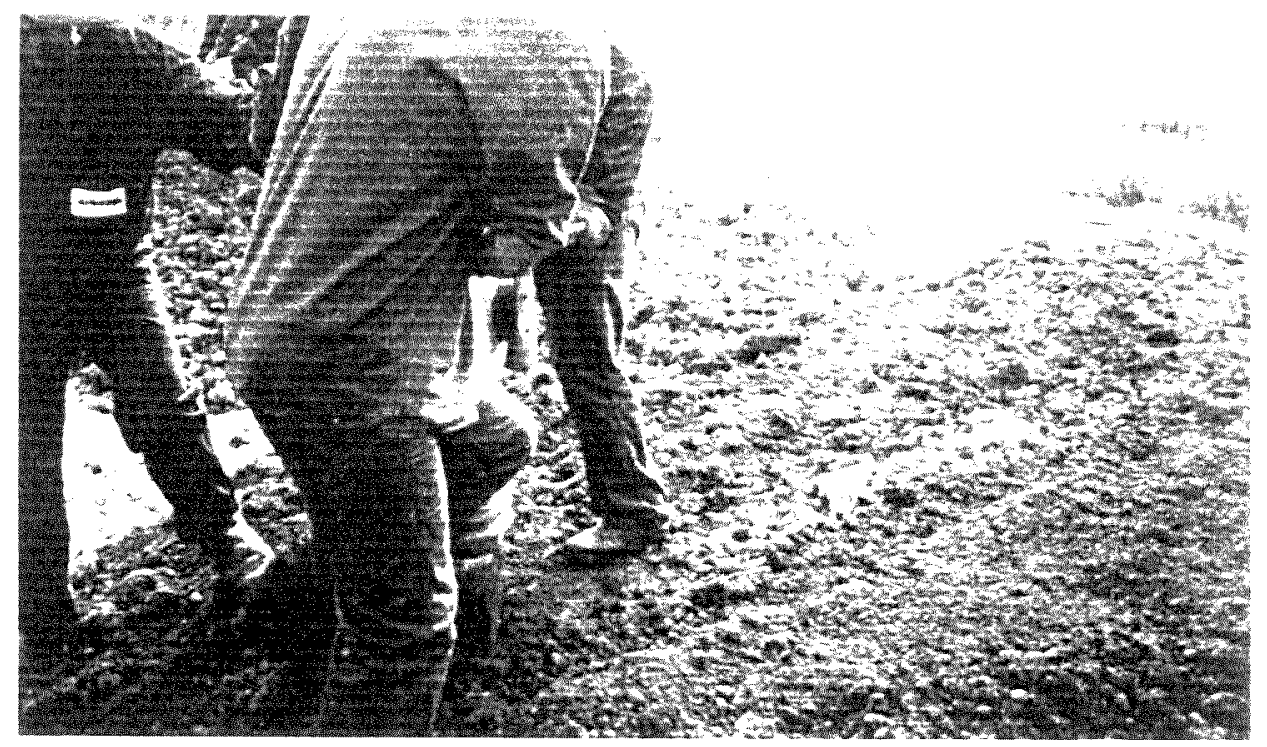

Figura 34: Compactação da pista com $8 \%$ de cal e $4 \%$ de Absorsol

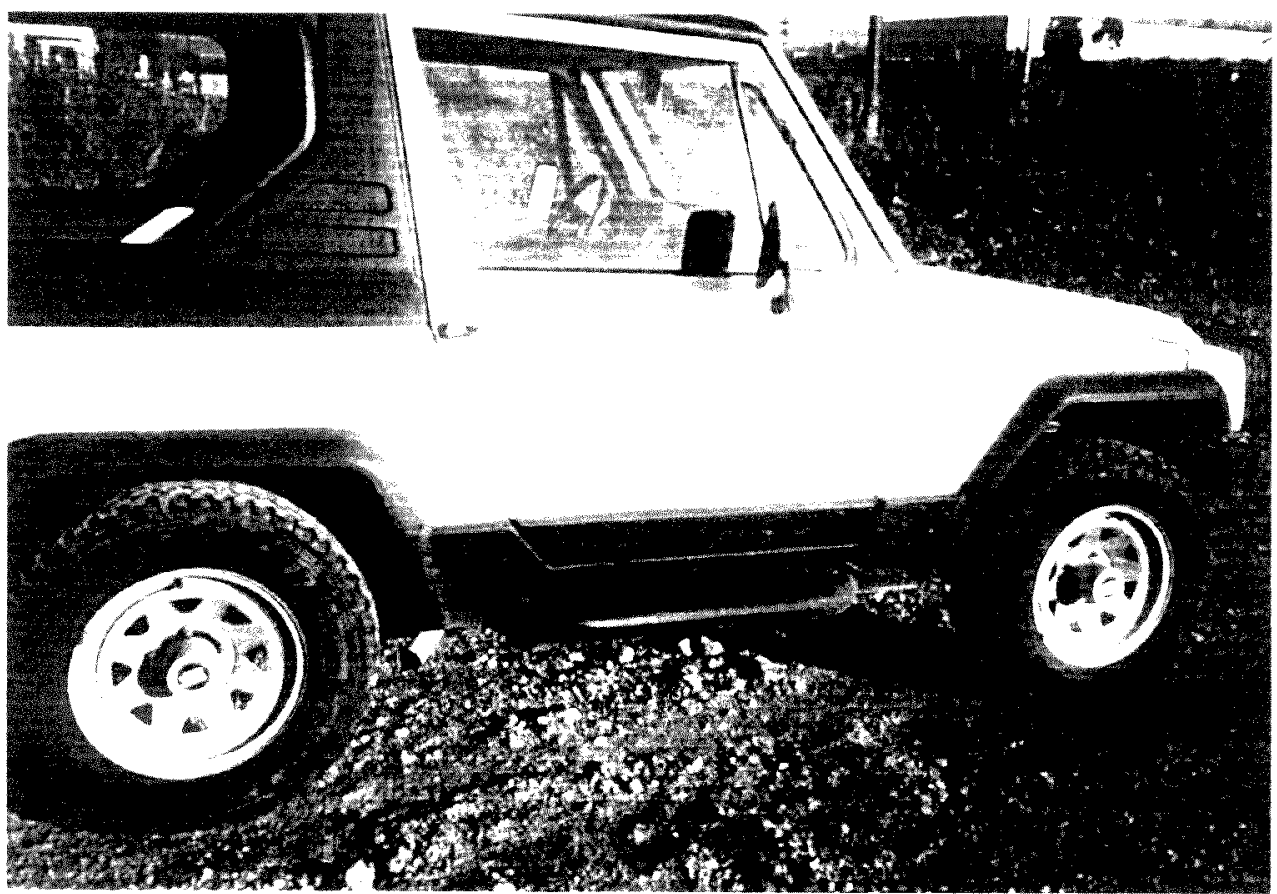

Figura 35: Pista de tortas de lodo com $8 \%$ de cal e $4 \%$ de Absorsol 30 dias após a compactação 


\subsubsection{Coleta de amostras para tortas précondicionadas com polímero}

Como já mencionado, o précondicionamento do lodo digerido anaerobiamente foi alterado em fins de 1998, tendo passado a receber exclusivamente polímeros em vez de cal e cloreto férrico. Posteriormente, em dezembro de 2001, voltou a receber também cloreto férrico juntamente com polímeros (vide item 3.4). Os testes realizados em 1999 , objeto dos itens seguintes, dizem respeito aos estudos de laboratório feitos quando apenas polímeros foram usados antes do filtro-prensa. Os ensaios de campo não prosseguiram até a fase de pistas experimentais porque os resultados obtidos no laboratório revelaram que a retirada da cal no précondicionamento traria inviabilidade de suporte pelo menos até a dosagem máxima de cal anteriormente pós-adicionada de $17,5 \%$ em peso.

Deve também ser lembrado que para a mesma dosagem em peso $(17,5 \% \mathrm{CaO} / \mathrm{ST}) \mathrm{o}$ consumo de cal virgem já seria maior para as tortas atuais mais úmidas, porque o mesmo peso só seria alcançado com volumes maiores de lodo.

A amostragem para os estudos assumiu algumas simplificações de metodologia fundamentando-se na grande homogeneidade da torta que havia sido constatada quando feita a coleta e análise de amostras das tortas précondicionadas com cal em 1998. O escopo das verificações foi limitado aos estudos geotécnicos de laboratório.

Foram colhidas nove amostras com cerca de $30 \mathrm{~kg}$ cada de uma descarga do filtro prensa, mantidas em recipientes fechados para evitar perda de umidade até a chegada ao laboratório.

\subsubsection{Ensaios de laboratório a partir das tortas de lodo précondicionadas com polímero}

No laboratório foram realizadas as seguintes operações: 
- mistura com cal virgem, nas proporções de $5 \%, 10 \%, 15 \%$ e $20 \%$, (peso de cal / peso da torta);

- preparação (em duplicata) de corpos de prova na data de retirada das amostras para ensaios de resistência à compressão simples e determinação do índice de suporte Califörnia, nas misturas cal /amostra de 0\%, 5\%, 10\%, 15\% e 20\%;

- preparação dos corpos de prova, nas mesmas condições anteriores, para as idades de 5, 14 e 21 dias da amostragem;

As amostras de torta foram misturadas com cal virgem com os seguintes porcentuais em peso seguintes:

Cal virgem adicional misturado às tortas précondicionadas com polímero

$$
\begin{gathered}
0 \% \\
5 \% \\
10 \% \\
15 \% \\
20 \%
\end{gathered}
$$

As cinco amostras resultantes foram acondicionadas em tambores que permaneceram fechados ate as datas de execução dos ensaios programados.

Durante e após a adição de cal foram efetuadas medições da temperatura das amostras, encontrando-se os seguintes resultados: 
Tabela 26: Temperaturas das amostras de lodo decorrentes da adição de cal virgem

\begin{tabular}{|c|c|c|c|c|}
\hline \multirow{2}{*}{$\begin{array}{l}\text { Tempo após a } \\
\text { mistura }\end{array}$} & \multicolumn{4}{|c|}{ Acréscimo porcentual de cal virgem } \\
\hline & $5 \%$ & $10 \%$ & $15 \%$ & $20 \%$ \\
\hline 2 horas & $50^{\circ} \mathrm{C}$ & $55^{\circ} \mathrm{C}$ & $55^{\circ} \mathrm{C}$ & $65^{\circ} \mathrm{C}$ \\
\hline 3 horas & $50^{\circ} \mathrm{C}$ & $55^{\circ} \mathrm{C}$ & $60^{\circ} \mathrm{C}$ & $70^{\circ} \mathrm{C}$ \\
\hline
\end{tabular}

Embora o $\mathrm{pH}$ não tenha sido determinado, a conservação da temperatura de $70^{\circ} \mathrm{C}$ por 30 minutos ou mais garante a pasteurização do lodo, tratando-se de processo aceito pela Cetesb para produção de biossólido classe A. Quanto ao $\mathrm{pH} \mathrm{12,} \mathrm{a} \mathrm{norma} \mathrm{norte-}$ americana admite que haja estabilização necessária para o lodo ser classificado como B se a quantidade de cal adicionada fizer o $\mathrm{pH}$ subir até 12, ou mais, no máximo em duas horas, sem especificar quanto tempo deve permanecer igual a 12. A norma da Cetesb exige que o $\mathrm{pH}$ suba até 12 e fique em 12, ou mais, pelo menos durante duas horas (Santos, 2001). No caso, as amostras voltaram para a temperatura ambiente em menos de 12 horas após a adição de cal virgem.

A Figura 36 mostra a torta preparada com polímero e misturada com cal no piso do laboratório, para inicio dos ensaios geotécnicos. 


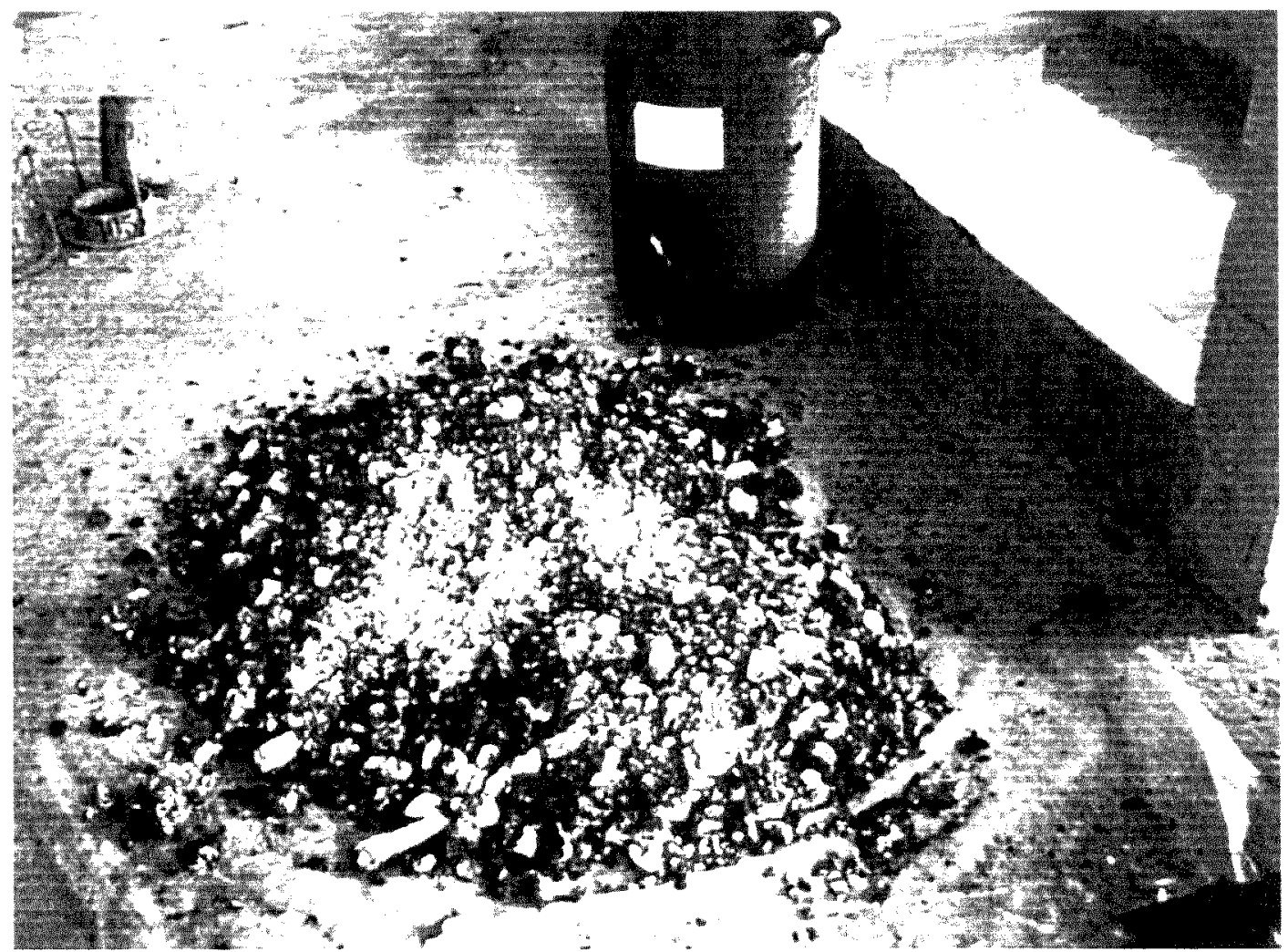

Figura 36: Torta preparada com polímero misturada com cal no laboratório

4.2.7.1 Ensaios de resistência à compressão simples

Para execução dos ensaios pela NBR 12.770, 1992, foram preparados corpos-de-prova cilíndricos, em duplicata, para as misturas de torta mais cal para cada uma das condições seguintes:

Mistura de cal a $0,5,10,15$ e $20 \%$ com a torta

a 0 dias

Mistura de cal a $0,5,10,15$ e $20 \%$ com a torta

a 5 dias

Mistura de cal a $0,5,10,15$ e $20 \%$ com a torta

a 14 dias

Mistura de cal a $0,5,10,15$ e 20\% com a torta

a 21 dias. 
Totalizando assim 40 corpos de prova para 40 ensaios. A Figura 37 mostra o aspecto dos corpos de prova, já rompidos, com porcentagens diferentes de cal. As figuras seguintes, diversas ações no laboratório que ocorreram entre as Figuras 36 e 40.

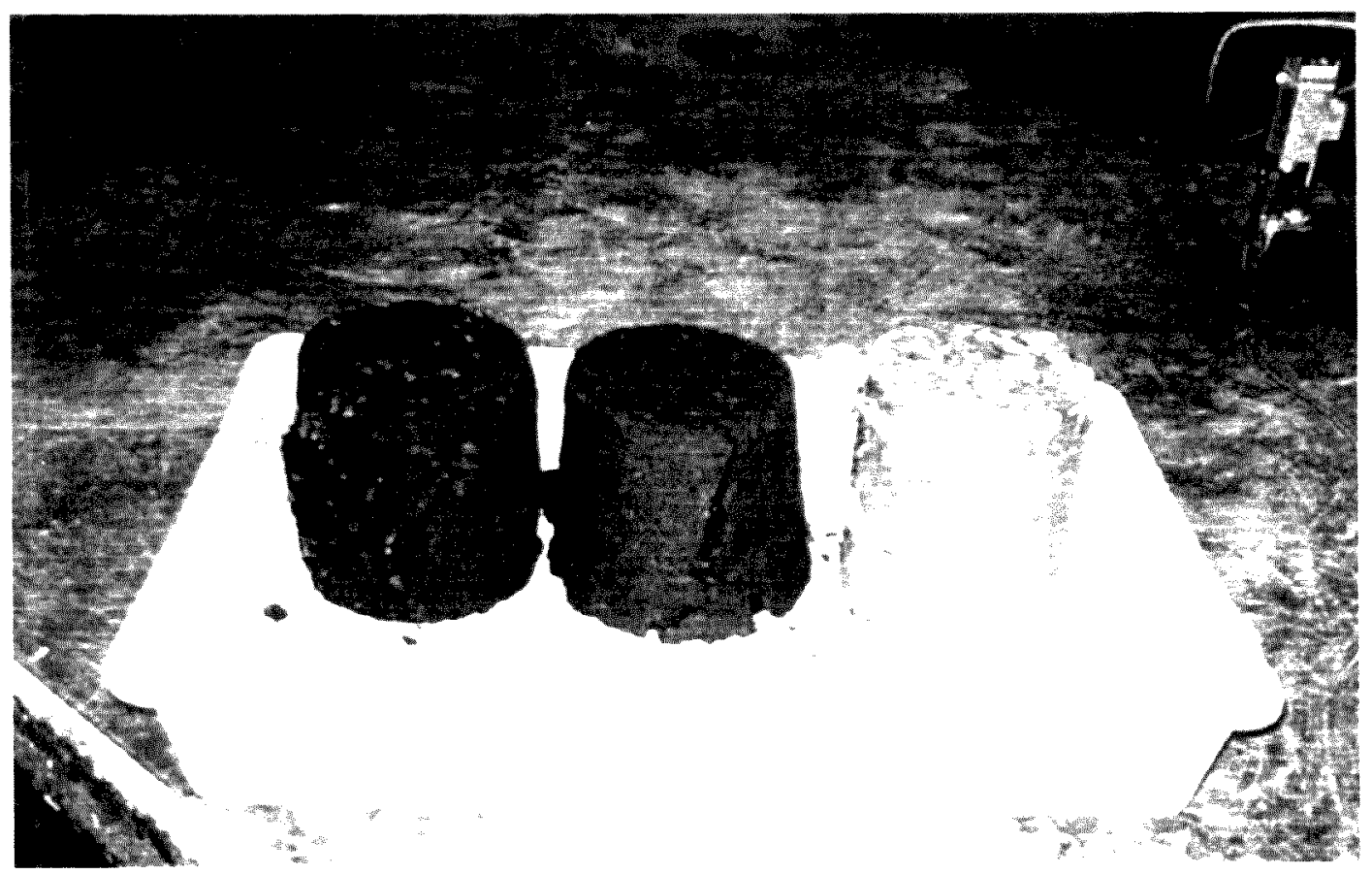

Figura 37: Da esquerda para a direita corpos de prova, rompidos, com 5\%, $10 \%$ e $20 \%$ de cal 


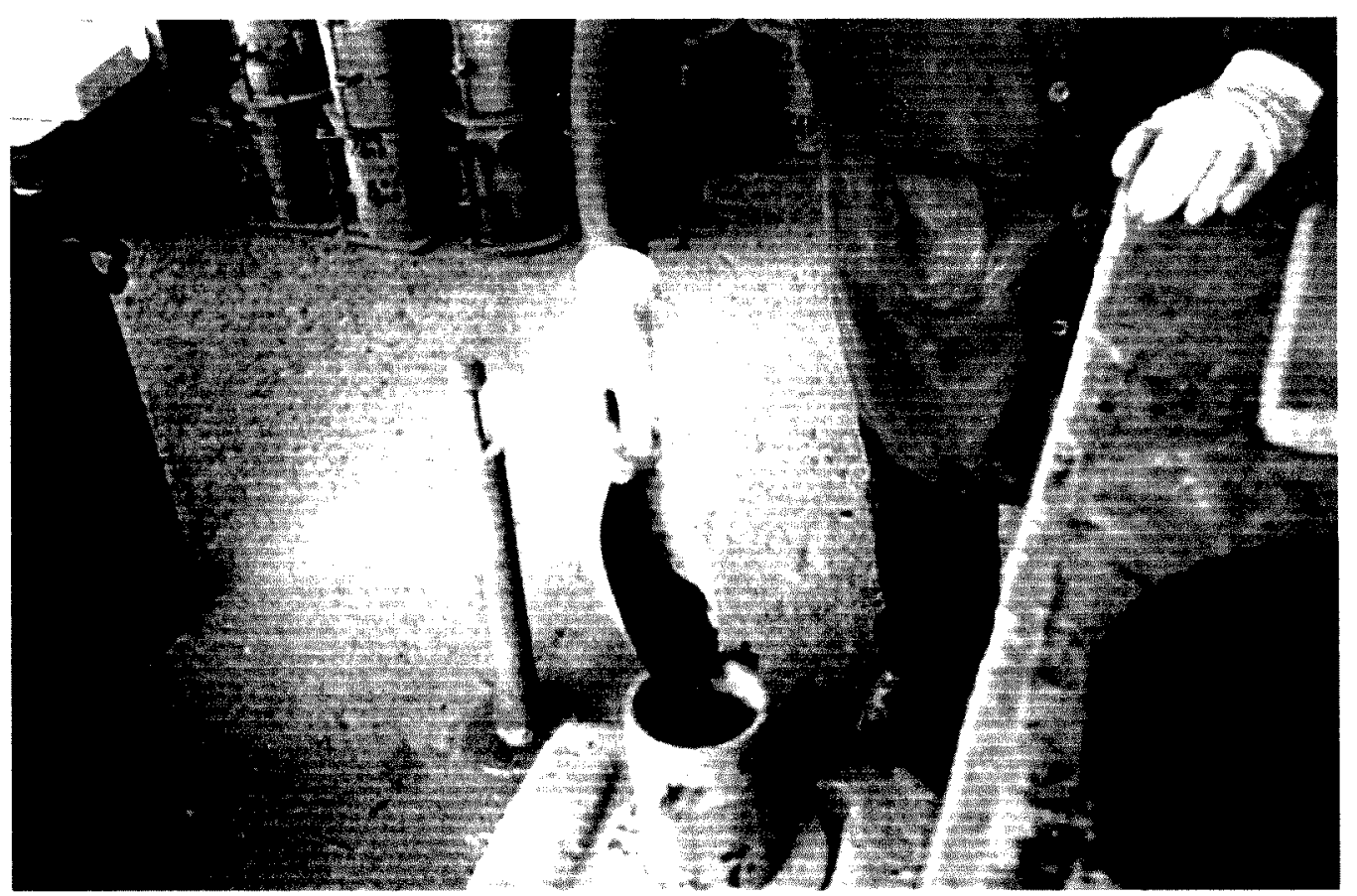

Figura 38: Colocação da amostra em cilindro para moldar o corpo de prova 

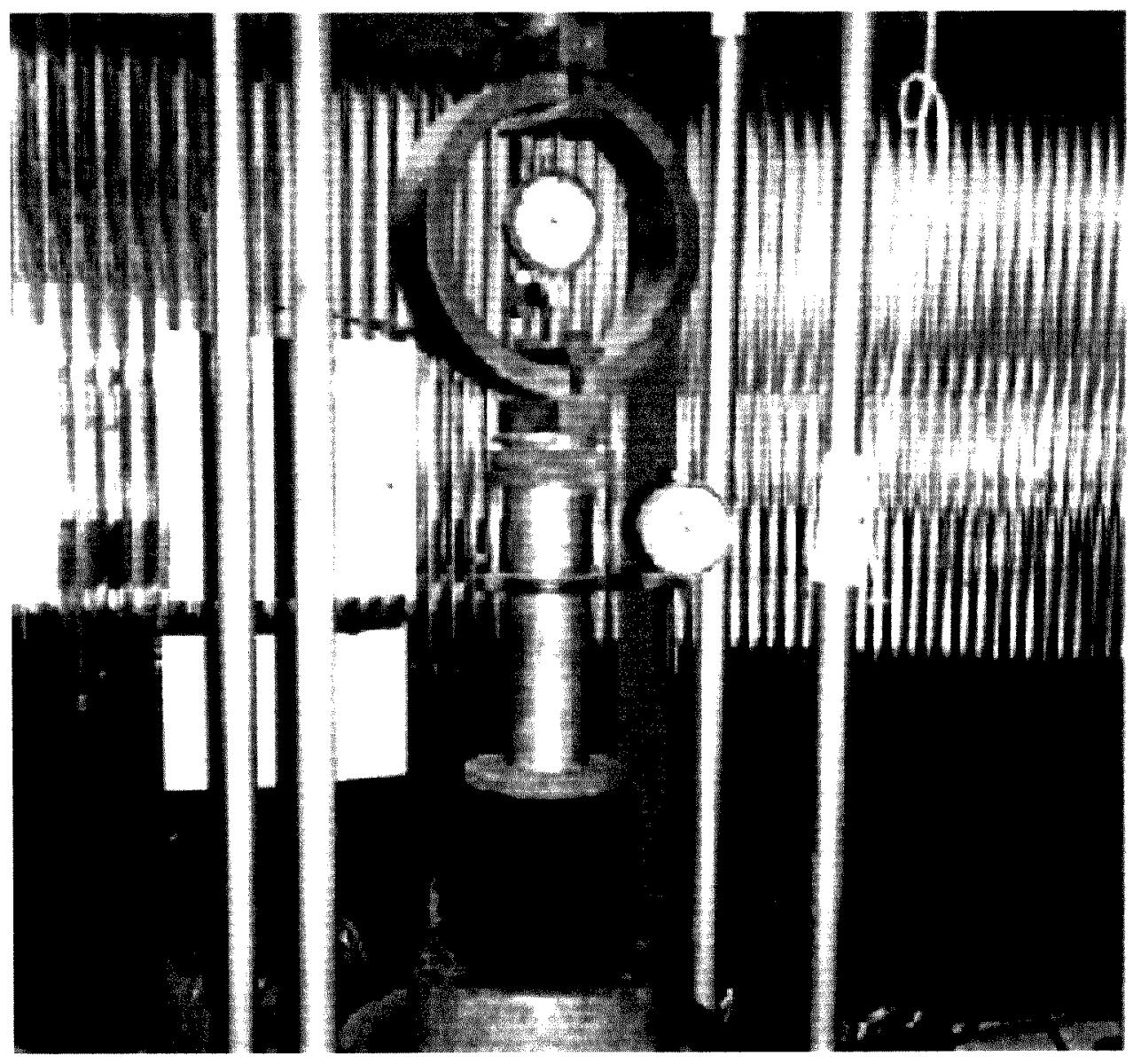

Figura 39: Rompimento de corpo de corpo de prova com 5\% de cal, sendo mostrado o anel dinamométrico utilizado para determinar os esforços aplicados. 


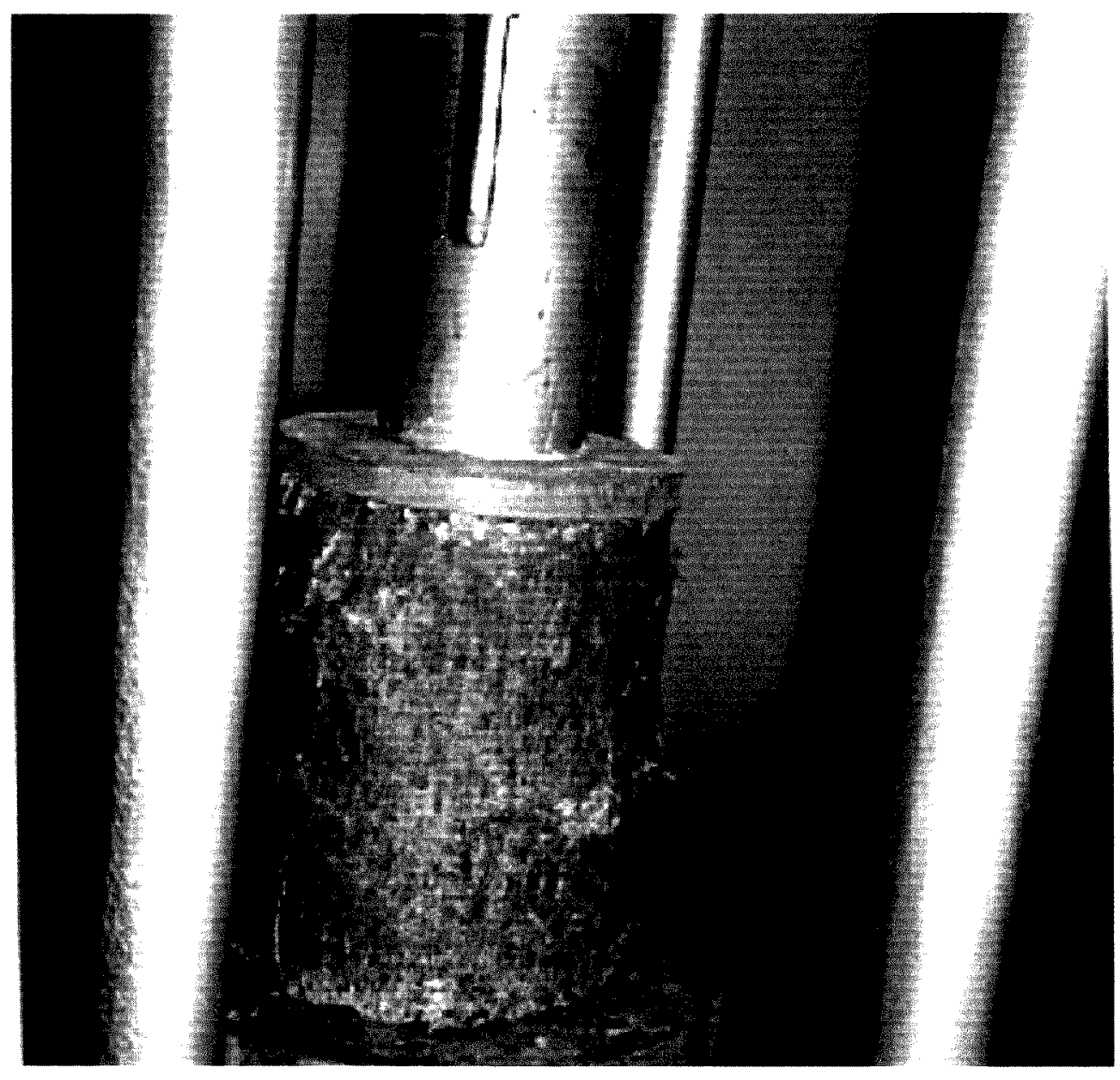

Figura 40: Rompimento de corpo de prova com $20 \%$ de cal 
A Figura 41 mostra graficamente a média dos resultados da resistência à compressão simples de dois ensaios por amostra das dosagens indicadas de cal adicional.

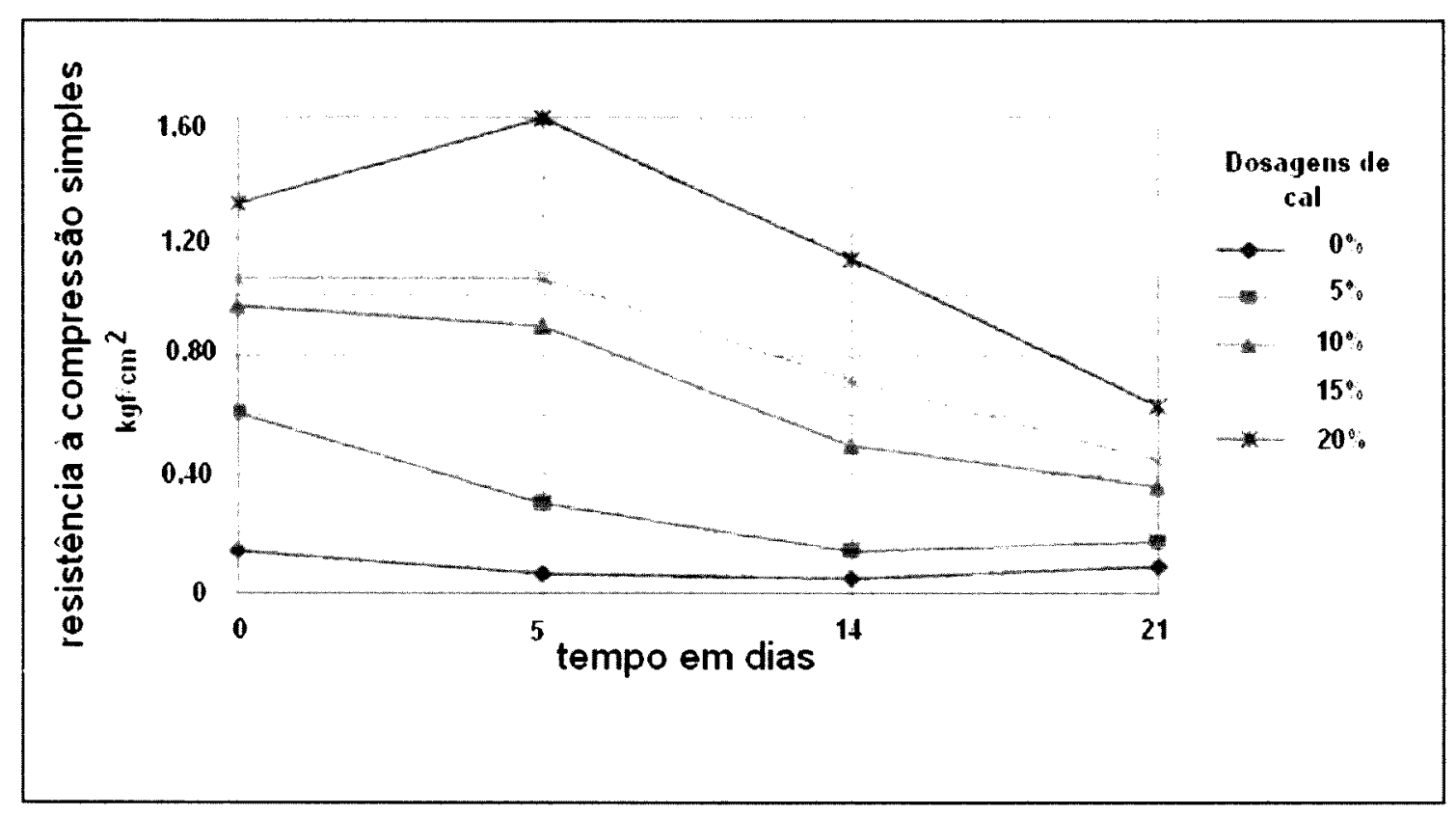

Figura 41: Ensaio de compressão simples para dosagens diversas de cal nas tortas précondicionadas com polímeros

Fonte: Adaptado de Alphageos, 1999

Pode ser observado que as dosagens mais elevadas de cal (15\% e $20 \%$ ) obtiveram uma resistência a compressão simples sempre superior a $0,4 \mathrm{kgf} / \mathrm{cm}^{2}$ no período de 21 dias. Entretanto, também pode ser notado que a tendência de todas as curvas é de nítida diminuição dos valores da resistência com a passagem dos dias, podendo-se prever, resultados inferiores na extrapolação de poucos dias, certamente menos de uma semana, bastando observar as curvas da Figura 41 .

Os resultados permitem concluir não ser viável a construção do aterro exclusivo com tortas précondicionadas com polímero, com fundamento neste indicador 


\subsubsection{Ensaios de determinação do Índice Suporte Califórnia}

Os ensaios foram realizados conforme a NBR 9.895 de junho de 1.987 - Solo - Índice de Suporte Califórnia. Foram preparados corpos-de-prova cilindricos, em duplicata, para as misturas de torta mais cal para cada uma das condições seguintes, da mesma forma que foi realizada anteriormente para os ensaios de compressão simples:

Mistura de cal a $0,5,10,15$ e $20 \%$ com a torta

Mistura de cal a $0,5,10,15$ e $20 \%$ com a torta

Mistura de cal a $0,5,10,15$ e $20 \%$ com a torta

Mistura de cal a $0,5,10,15$ e $20 \%$ com a torta a 0 dias

a 5 dias

a 14 dias

a 21 dias

Resultando, como antes, em 40 corpos de prova para 40 ensaios. As fotos na seqüencia ilustram as atividades desenvolvidas no laboratório. 


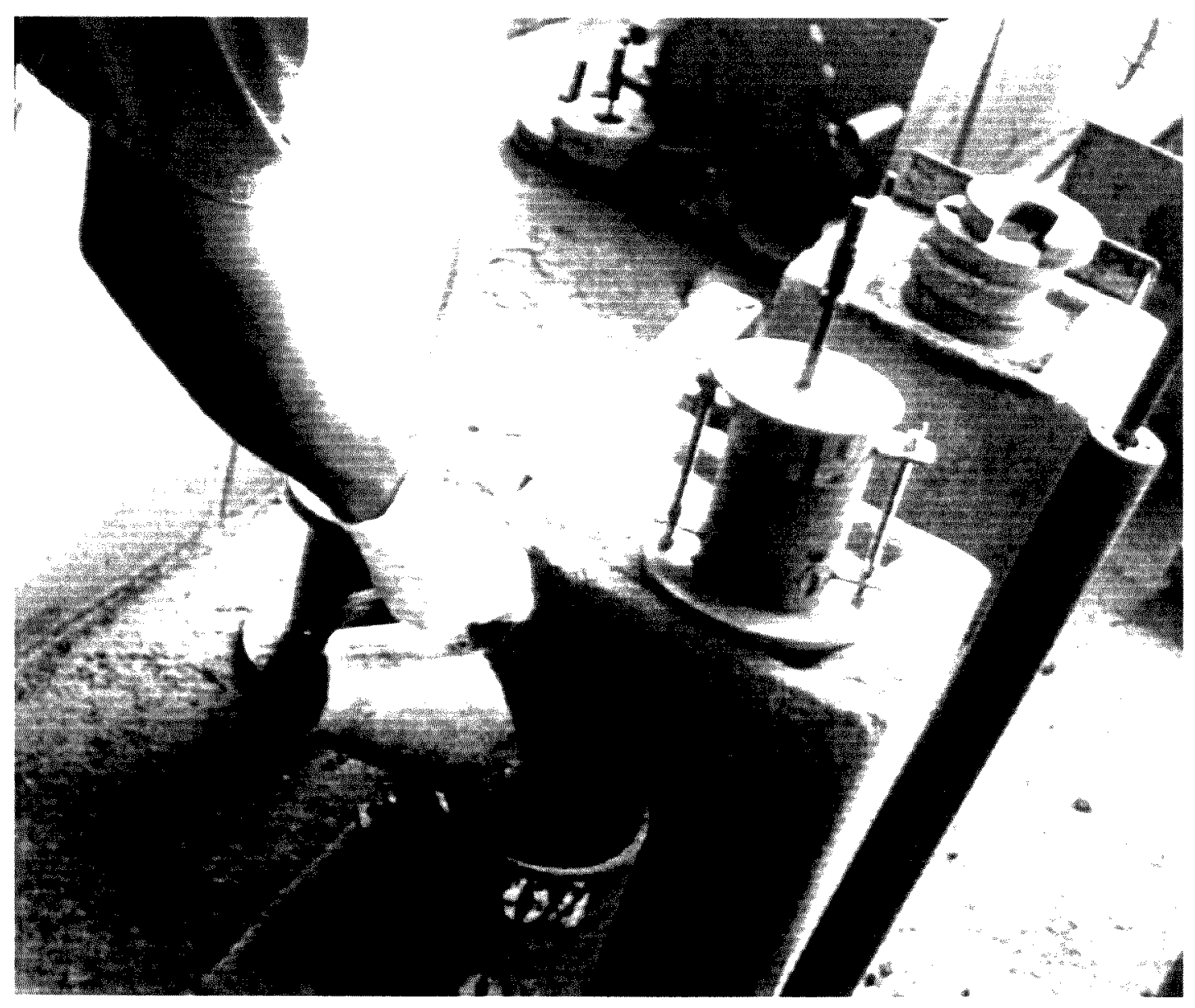

Figura 42: ISC: Colocação da amostra homogeneizada no molde cilíndrico 


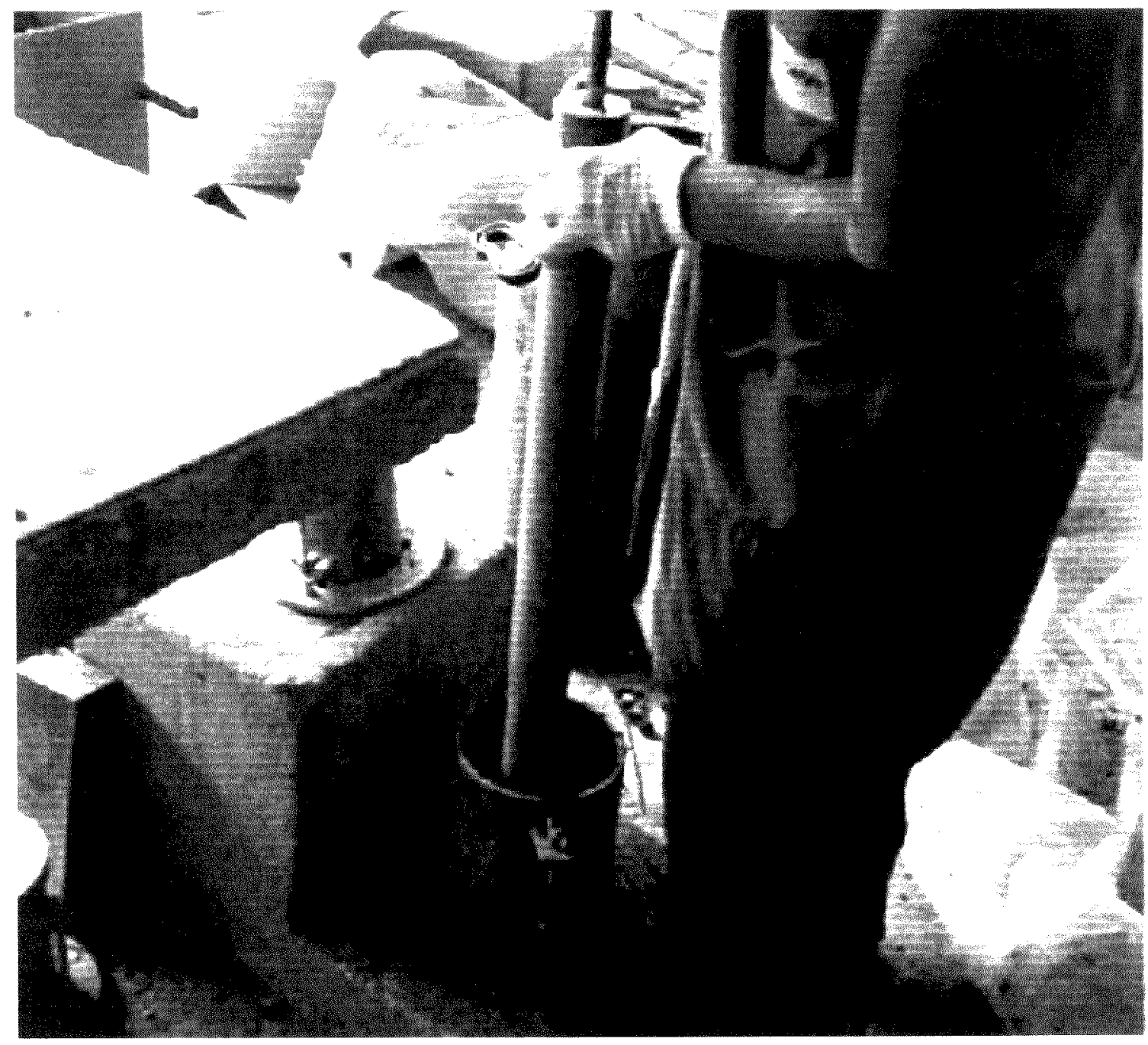

Figura 43: ISC: Compactação da amostra com peso e altura de queda conforme especificação do ensaio. 


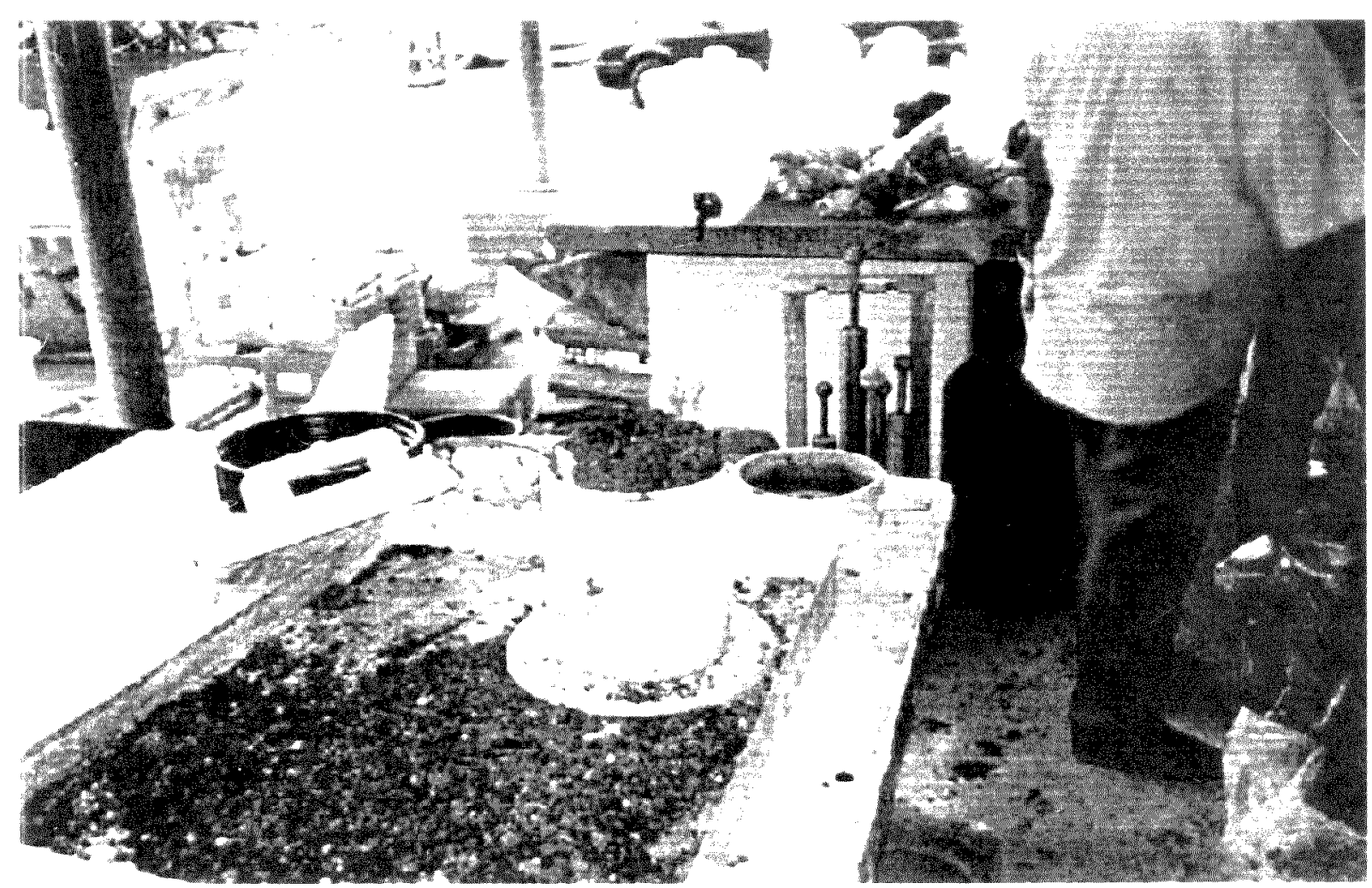

Figura 44: ISC: Preparação da amostra para a pesagem

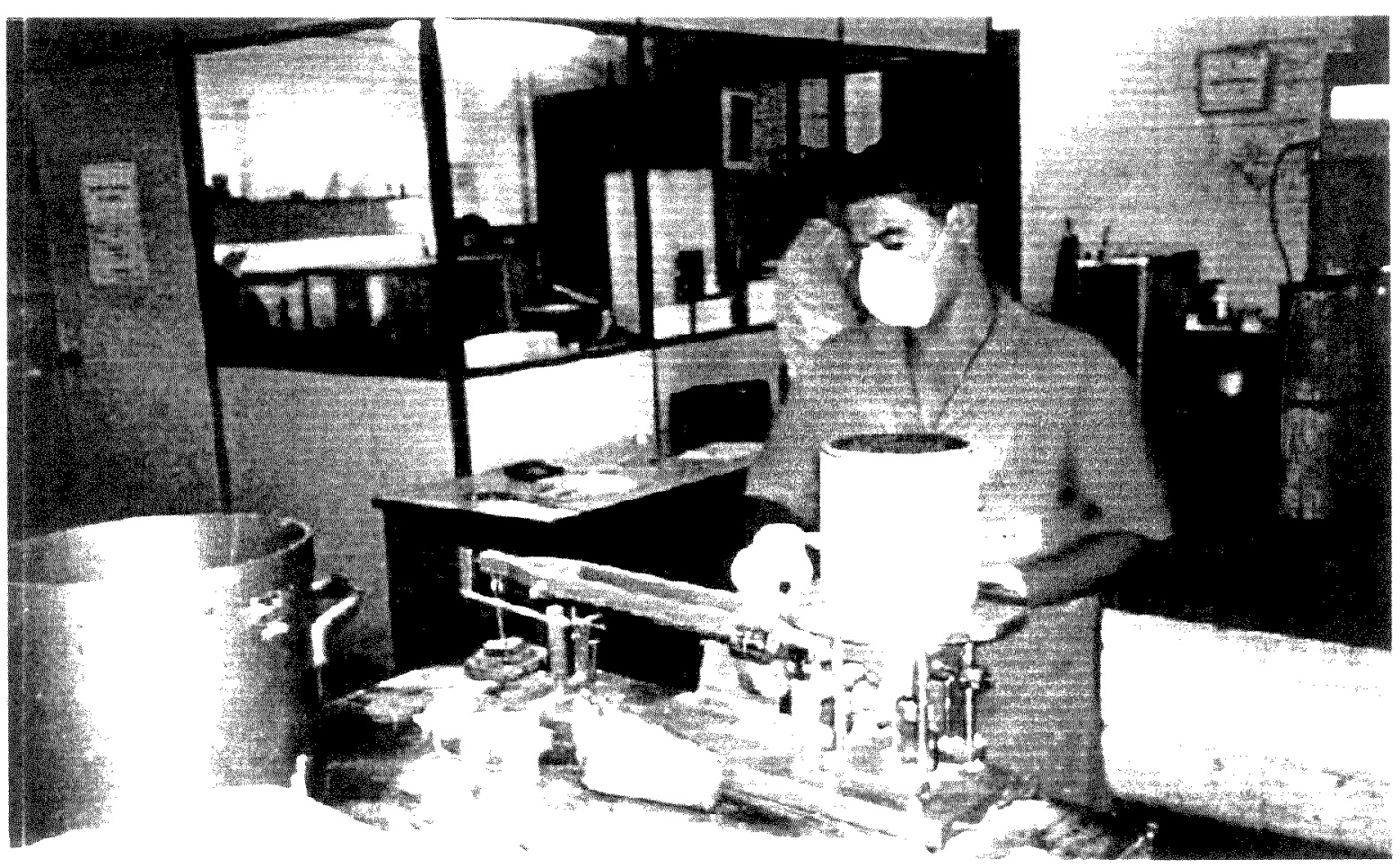

Figura 45: Pesagem do molde cilindrico contendo a amostra 


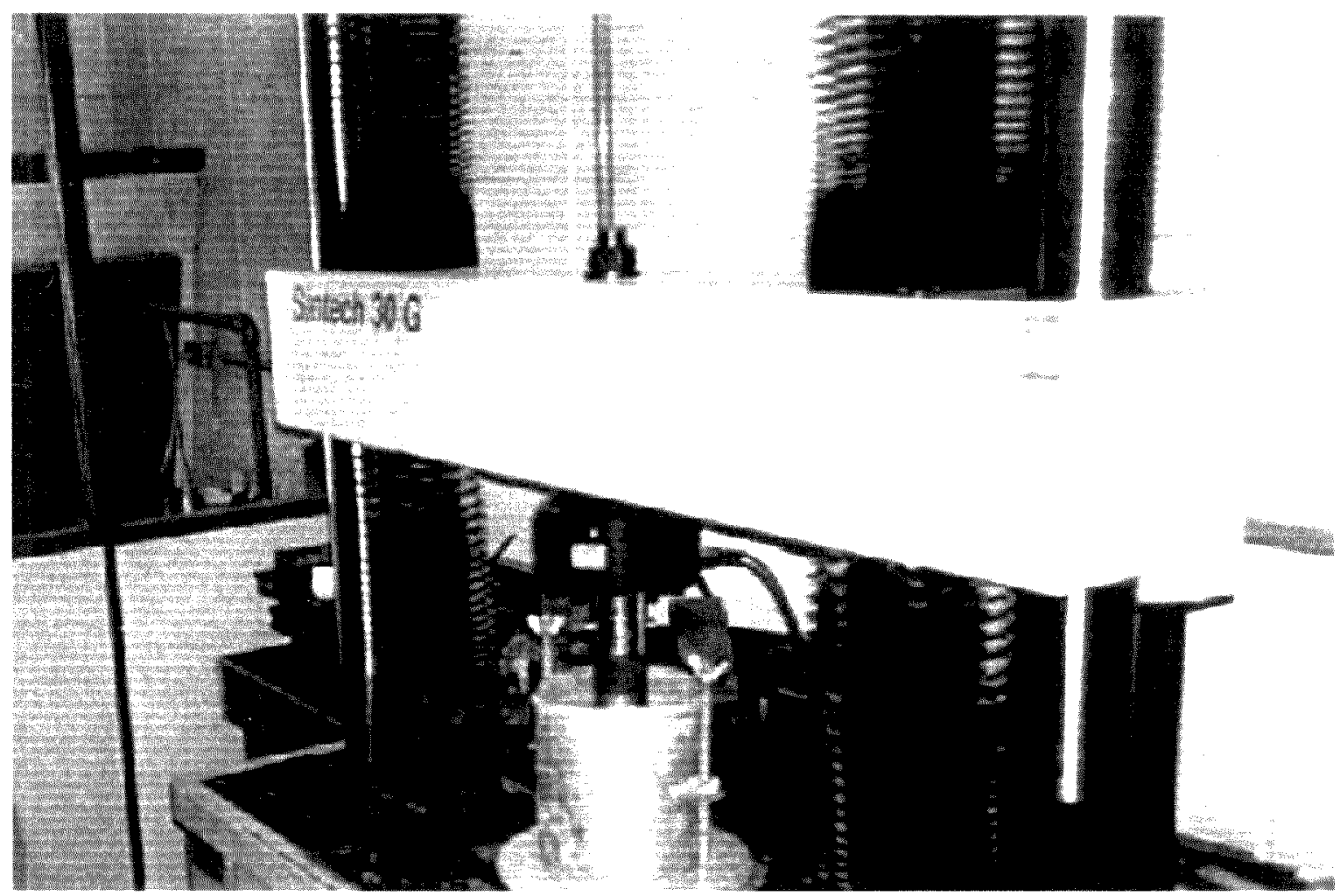

Figura 46: Amostra sendo prensada com destaque para o pistão de penetração 
A Figura 47 mostra graficamente a média dos resultados da determinação do ISC para dois ensaios por amostra das dosagens indicadas pela legenda de cal adicional.

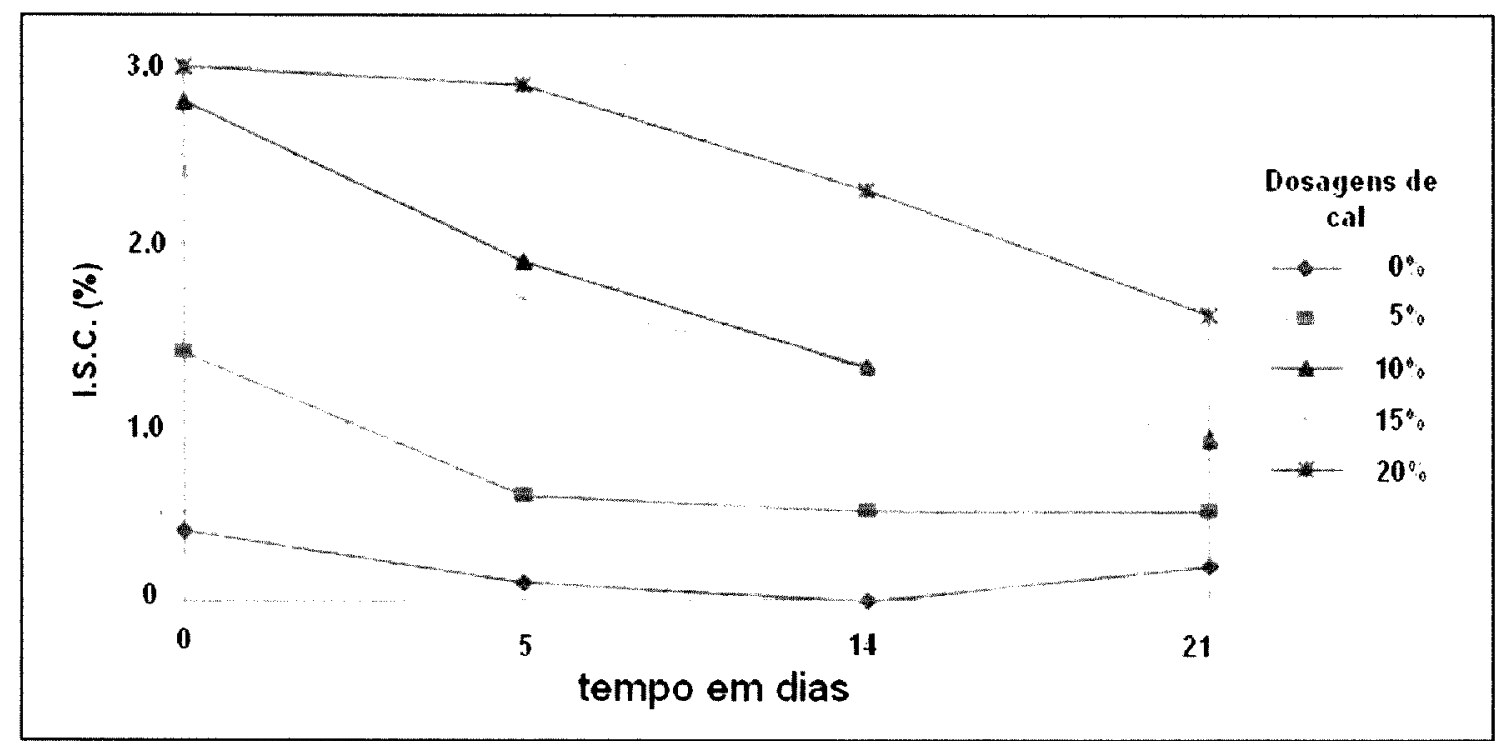

Figura 47: Ensaio de determinação do ISC para dosagens diversas de cal nas tortas précondicionadas com polímeros

Fonte: Adaptado de Alphageos, 1999

Observa-se que para todas dosagens de cal virgem na torta até $20 \%$ ST obtém-se um ISC decrescente com o tempo e terminando abaixo de $2 \mathrm{kgf} / \mathrm{cm}^{2}$ após 21 dias, o que indica não ser viável a construção de um aterro exclusivo de tortas de filtro-prensa précondicionadas com polímero, mesmo com adições de cal em peso de até $20 \%$.

4.2.7.3 Resumo dos ensaios geotécnicos de laboratório com as tortas de filtro prensa précondicionadas com polímeros para várias dosagens de cal

A Tabela 27 mostra os resultados, para duas amostras, dos ensaios geotécnicos realizados com a torta condicionada com polímeros. 
Tabela 27 Média dos resultados para duas amostras dos ensaios de compressão simples e ISC para tortas précondicionadas com polímeros

\begin{tabular}{|c|c|c|c|c|c|c|c|c|c|c|c|c|c|c|c|c|}
\hline \multirow[b]{3}{*}{ A mostras 1 e 2} & & \multicolumn{15}{|c|}{ Dosagens de cal virgem } \\
\hline & & \multicolumn{2}{|c|}{$0 \%$} & \multirow{2}{*}{ média } & \multicolumn{2}{|c|}{$5 \%$} & \multirow{2}{*}{ média - } & \multicolumn{2}{|c|}{$10 \%$} & \multirow{2}{*}{ média } & \multicolumn{2}{|c|}{$15 \%$} & \multicolumn{3}{|c|}{$20 \%$} & \multirow{2}{*}{-média } \\
\hline & & 1 & 2 & & 1 & 2 & & 1 & 2 & & 1 & 2 & . & 1 & 2 & \\
\hline $\begin{array}{l}\text { Densidade úmida } \\
\text { Concentraçăo de sólidos }\end{array}$ & $\mathrm{g} / \mathrm{cm}^{3}$ & $\begin{array}{r}1,107 \\
40,8 \%\end{array}$ & $\begin{array}{r}1,105 \\
41,3 \%\end{array}$ & $\begin{array}{r}1,106 \\
41,1 \%\end{array}$ & $\begin{array}{r}1,11 \\
44,4 \%\end{array}$ & $\begin{array}{r}1,146 \\
46,1 \%\end{array}$ & $\begin{array}{r}1,128 \\
45,3 \%\end{array}$ & $\begin{array}{r}1,172 \\
56,2 \%\end{array}$ & $\begin{array}{r}1,179 \\
54,9 \%\end{array}$ & $\begin{array}{r}1,176 \\
55,6 \%\end{array}$ & $\begin{array}{r}1,249 \\
56,7 \%\end{array}$ & $\begin{array}{r}1,276 \\
64,0 \%\end{array}$ & $\begin{array}{r}1,263 \\
60,4 \%\end{array}$ & $\begin{array}{r}1,086 \\
56,8 \%\end{array}$ & $\begin{array}{r}1,231 \\
63,4^{\circ} \%\end{array}$ & $\begin{array}{r}1,159 \\
60,1 \%\end{array}$ \\
\hline Indice de Suporte Califomia & $\mathrm{kgf} / \mathrm{cm}^{2}$ & 0,3 & 0,4 & 0,350 & 1,3 & 1.5 & 1,400 & 2,9 & 2,7 & 2,800 & 2,4 & 2,5 & 2,450 & 2,9 & 3,1 & 3,000 \\
\hline Resistência à Compressão Simples & $\mathrm{kg} / \mathrm{cm}^{2}$ & 0,14 & 0,14 & 0,140 & 0,59 & 0,63 & 0,610 & 0,99 & 0,95 & 0,970 & 1,08 & 1,04 & 1,060 & 1,35 & 1,26 & 1,305 \\
\hline
\end{tabular}

Densidade úmida
Concentraçåo de sólidos
Indice de Suporte Califomia
\& Resistència à Compressão Simples

$$
\begin{array}{|l|rr}
\mathrm{g} / \mathrm{cm}^{3} & 1,087 & 1,096 \\
& 36,3 \% & 36,2 \% \\
\mathrm{kgf} / \mathrm{cm}^{2} & 0,12 & 0,05 \\
\mathrm{~kg} / \mathrm{cm}^{2} & 0 & 0,14
\end{array}
$$

$\mathbf{1 , 0 9 2} \mid$\begin{tabular}{lll|ll|}
1,17 & 1,173 & $\mathbf{1 , 1 7 2}$ & 1,253 & 1,236
\end{tabular} \begin{tabular}{l|lll|llll}
$64,1 \%$ & $56,3 \%$ & $56,4 \%$ & $56,4 \%$ & $64,4 \%$ & $66,7 \%$ & $65,6 \%$
\end{tabular} \begin{tabular}{l|lll|lll|lll|lll|}
$\mathbf{0 , 0 8 5}$ & 0,59 & 0,54 & $\mathbf{0 , 5 6 5}$ & 1,83 & 1,98 & $\mathbf{1 , 9 0 5}$ & 1,38 & 2,03 & $\mathbf{1 , 7 0 5}$ & 2,72 & $\mathbf{3 , 1 1}$ & $\mathbf{2 , 9 1 5}$ \\
\hline
\end{tabular} $\begin{array}{lllllllllllll}\mathbf{0 , 0 7 0} & 0,27 & 0,32 & \mathbf{0 , 3 0 0} & 0,9 & 0,9 & \mathbf{0 , 9 0 0} & 1,08 & 1,04 & 1,060 & 1,62 & 1,58 & 1,600\end{array}$

\section{E. Densidade úmida}

Concentração de sólidos

I Indice de Suporte Califomia

$$
\begin{array}{|l|rr}
\mathrm{g} / \mathrm{cm}^{3} & 1,07 & 1,08 \\
& 64,5 \% & 65,1 \% \\
\mathrm{~kg} / \mathrm{cm}^{2} & 0 & 0 \\
\mathrm{~kg} / \mathrm{cm}^{2} & 0,05 & 0,05
\end{array}
$$

\begin{tabular}{r|rrr|rr|}
1,075 & 1,176 & 1,18 & 1,178 & 1,254 & 1,248
\end{tabular}

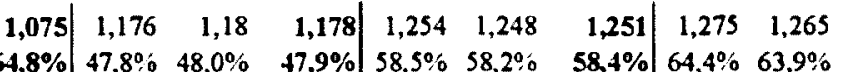
\begin{tabular}{llllllllllll}
0 & $48,0 \%$ & $47,9 \%$ & $58,5 \%$ & $58,2 \%$ & $58,4 \%$ & $64,4 \%$ & $63,9 \%$ & $64,2 \%$ & $66,2 \%$ & $65,9 \%$ & $66,1 \%$ \\
\hline
\end{tabular}

$<$ Resistència à Compressăo Simples

\begin{tabular}{|c|c|c|c|c|c|c|c|c|c|c|c|c|c|c|c|c|}
\hline $\begin{array}{l}\text { Densidade úmida } \\
\text { Concentração de sólidos }\end{array}$ & $\mathrm{g} / \mathrm{cm}^{3}$ & $\begin{array}{r}1,156 \\
38,0 \%\end{array}$ & $\begin{array}{r}1,152 \\
37,8 \%\end{array}$ & $\begin{array}{r}1,154 \\
37,9 \%\end{array}$ & $\begin{array}{r}1,176 \\
45,2 \%\end{array}$ & $\begin{array}{r}1,18 \\
45,4 \%\end{array}$ & $\begin{array}{r}1,178 \\
+5,3 \%\end{array}$ & $\begin{array}{r}1,25 \\
58,2 \%\end{array}$ & $\begin{array}{r}1,263 \\
58,8^{\circ}\end{array}$ & $\begin{array}{r}1,257 \\
58,5 \%\end{array}$ & $\begin{array}{r}1,252 \\
71,9 \%\end{array}$ & $\begin{array}{r}1,26 \\
72,4 \%\end{array}$ & $\begin{array}{r}1,256 \\
72,2 \%\end{array}$ & $\begin{array}{r}1,29 \\
67.2 \%\end{array}$ & $\begin{array}{r}1,278 \\
66,5 \% \%\end{array}$ & $\begin{array}{r}1,284 \\
66,9 \%\end{array}$ \\
\hline Resistència à Compressão Simples & $\mathrm{kg} / \mathrm{cm}^{2}$ & 0,09 & 0,09 & 0,090 & 0,19 & 0.17 & 0,180 & 0,39 & 0.33 & 0,360 & 0.42 & 0,48 & 0,450 & 0,6 & 0.66 & 0,630 \\
\hline
\end{tabular}
$\begin{array}{llll}\mathbf{0 , 0 5 0} & \mathbf{0 , 1 4} & 0,14 & \mathbf{0 , 1 4 0}\end{array} \quad 0,51$ 
Como pode ser observado, para todas dosagens houve uma diminuição da resistência à compressão simples após os cinco dias e do ISC desde o início, terminando aos 21 dias, para a maior dosagem experimentada $(21 \%$ de cal virgem em base seca das tortas do filtro) com o a resistência de $0,63 \mathrm{~kg} / \mathrm{cm}^{2}$ e o ISC de $1,6 \mathrm{kgf} / \mathrm{cm}^{2}$.

Construir os aterros exclusivos com tortas précondicionadas com polímero se apresenta como desaconselhável, menos pelos valores alcançados aos 21 dias do que pela tendência de diminuição de ambos indicadores com a passagem do tempo, o contrario do que seria desejável para a viabilidade construtiva da obra. 


\section{RESULTADOS}

1. Os ensaios geotécnicos nas pistas construídas com tortas précondicionadas com cal mostraram que os aterros exclusivos poderiam ser construídos com adoção de $17,5 \%$ de cal virgem em peso.

2. Os ensaios revelaram que se a porcentagem de cal fosse diminuída para $8 \%$ e se fosse adicionado $4 \%$ de Absorsol à mistura com as tortas as pistas ainda poderiam ser construídas. Os gráficos mostraram tendência de aumento dos indicadores de resistência ao tráfego com a passagem do tempo e a resistência foi comprovada com tráfego após um mês da construção (Figuras 33 e 34).

3. Foi também verificado que o uso do Absorsol evitou o desprendimento de amônia, quer na mistura com o lodo, quer no lançamento e compactação das tortas nas pistas pelo trator $D-4$.

4. Os ensaios de laboratório mostraram que não seria viável construir pistas experimentais com as tortas do filtro-prensa depois que polímeros passaram a ser usados no seu précondicionamento. Construir os aterros exclusivos com essas tortas seria desaconselhável pela tendência de diminuição dos valores doa resistência a compressão simples e do ISC com a passagem do tempo, verificada para dosagens de até $20 \%$ de cal (base seca), o contrario do que seria desejável para a viabilidade construtiva da obra.

5. Foi constatado que o emprego de polímeros em vez de cal foi capaz de diminuir a taxa de produção de lodo por metro cúbico por segundo de esgotos tratados de 19,66 para 13,25 toneladas/dia (base seca), ou seja de 32,6\%, comparando-se dados do biênio 1993/94 com o de 1999/2000. 
6. A constituição fisico-quimica das amostras R, E, F, Cal-01, Cal-02, Cal-03, Abs01, Abs+Cal-01 e Abs+Cal-02, quando comparadas com os parametros de concentração máximas de metais permissiveis para uso agricola pela legislação norte-americana, indicam que as tortas de lodo produzidas, com ou sem aditivos adicionais, podem ser usadas na agricultura, como indicado na Tabela 28, exceto pela ressalva feita no item 7 da presente discriminação de resultados.

Tabela 28: Comparação da qualidade físico-química das amostras de torta précondicionada com cal e cloreto férrico, antes e depois da mistura com aditivos adicionais

\begin{tabular}{|c|c|c|c|c|c|c|c|c|c|c|}
\hline \multirow{3}{*}{ : } & \multirow{3}{*}{$\begin{array}{c}\text { Máximo } \\
\text { pela } \\
\text { “40 CFR } \\
\text { Part } \\
503 "\end{array}$} & \multicolumn{3}{|c|}{$\begin{array}{l}\text { Amostras antes de } \\
\text { aditivos adicionais }\end{array}$} & \multicolumn{6}{|c|}{$\begin{array}{l}\text { Amostras das pistas, após aditivos adicionais } \\
\text { (seria a qualidade no aterro exclusivo) }\end{array}$} \\
\hline & & $\mathrm{R}$ & & & $\begin{array}{l}\text { Cal } \\
01\end{array}$ & $\begin{array}{l}\text { Cal } \\
02\end{array}$ & $\begin{array}{l}\text { Cal } \\
03\end{array}$ & $\begin{array}{c}\text { Abs } \\
01\end{array}$ & $\begin{array}{c}\text { Abst } \\
\text { Cal } \\
\text { Ol }\end{array}$ & $\begin{array}{c}\mathrm{Abs}+ \\
\mathrm{Cal} \\
02\end{array}$ \\
\hline & & \multicolumn{9}{|c|}{$\begin{array}{l}\mathrm{Mg} \text { do elemento/kg de lodo em base seca, transformado o resultado para a } \\
\text { massa bruta (NBR 1004) } \\
\text { considerando a umidade da amostra }\left(^{*}\right)\end{array}$} \\
\hline As & 75 & $<12,5$ & $<12,5$ & $<12,5$ & $<10$ & $<10$ & $<10$ & $<12,5$ & $<11,5$ & $<12$ \\
\hline $\mathrm{Cd}$ & 85 & 10 & 7 & 7,3 & 6,4 & 6,4 & 7,2 & 9,0 & 9,2 & 8,6 \\
\hline $\mathrm{Cu}$ & 4300 & 450 & 430 & 400 & 312 & 244 & 268 & 360 & 354 & 341 \\
\hline $\mathrm{Pb}$ & 840 & 205 & 160 & 156 & 124 & 292 & 116 & 145 & 105 & 312 \\
\hline & 57 & 1,2 & 1,5 & 1,0 & 1,0 & 40,2 & 0,8 & 1,7 & $\infty 0,3$ & 0,7 \\
\hline & 75 & 20 & 20 & 16 & 12 & 32 & 28 & 20 & 23 & 24 \\
\hline Mo & 420 & 230 & 180 & 177 & 120 & 136 & 140 & 150 & 184 & 154 \\
\hline $\mathrm{Se}$ & 100 & $<2,5$ & $<2,5$ & $<2,6$ & $<2$ & $<2$ & $<2$ & $<2,5$ & $<2,3$ & 2,3 \\
\hline $\mathrm{Zn}$ & 7500 & 1800 & 1900 & 1716 & 1360 & 1160 & 1320 & 1600 & 1472 & 1440 \\
\hline
\end{tabular}

$\left(^{*}\right)$ Resultados para os metais listados, determinados na massa bruta para atender a NBR 10.004, que se encontram nas Tabelas 5, 8, 11, 14, 16, 18, 20, $22 \mathrm{e} 24$, divididos por $(100 \%-\%$ Umidade $)=$ $\%$ Sólidos, para serem expressos em base seca e poderem ser comparados com os limites da legislação norte-americana (ou da Cetesb, P-4230 de 1999, que são iguais)

7. Verificou-se que amostras das pistas CAL 01 e CAL 03 possuiam concentrações de fenóis de 16,20 e $15,86 \mathrm{mg} / \mathrm{kg}$ respectivamente, portanto acima do admissível para a classe II da NBR 10004, bem como a amostra da pista ABS + CAL 01, com $15,43 \mathrm{mg} / \mathrm{kg}$ de fenóis. O limite para a classe II da NBR 10.004 é de 10 $\mathrm{mg} / \mathrm{kg}$. O resíduo destas pistas foi classificado pelo laboratório como perigoso. 
8. A patogenicidade das amostras R, E, F, Cal-01, Cal-02, Cal-03, Abs-01, Abs + Cal-01 e Abs+Cal-02 foi verificada em relação aos indicadores coliformes fecais e Salmonellas sp.

Foi feita a comparação com a densidade de microrganismos admissiveis para uso irrestrito do lodo (classe A) e uso com restrições de taxas de aplicação, culturas e acesso publico (classe B) da 40 CFR Part 503 norte-americana. Os resultados desta comparação encontram-se na Tabela 29.

Tabela 29: Qualidade microbiológica das amostras de torta précondicionada com cal e cloreto férrico, antes e depois da mistura com aditivos adicionais (base seca)

\begin{tabular}{|c|c|c|c|c|c|c|c|c|c|c|}
\hline \multirow{2}{*}{$\begin{array}{l}0 \\
\vdots \\
\vdots \\
0 \\
0\end{array}$} & \multirow{2}{*}{$\begin{array}{l}\text { Parâmetros } \\
\text { de controle e } \\
\text { limites da } 40 \\
\text { CFR Part } \\
503\end{array}$} & \multicolumn{3}{|c|}{$\begin{array}{c}\text { Amostras antes } \\
\text { de aditivos } \\
\text { adicionais }\end{array}$} & \multicolumn{6}{|c|}{$\begin{array}{l}\text { Amostras das pistas, após aditivos adicionais } \\
\text { (seria a qualidade no aterro exclusivo) }\end{array}$} \\
\hline & & $\mathrm{R}$ & $\mathrm{E}$ & $\mathrm{F}$ & $\begin{array}{l}\mathrm{Cal} \\
01\end{array}$ & $\begin{array}{c}\text { Cal } \\
02\end{array}$ & $\begin{array}{c}\text { Cal } \\
03\end{array}$ & $\begin{array}{c}\mathrm{Abs} \\
01\end{array}$ & $\begin{array}{c}\text { Abs + } \\
\text { Cal } \\
01\end{array}$ & $\begin{array}{c}\mathrm{Abs}+ \\
\mathrm{Cal} \\
02\end{array}$ \\
\hline \multirow[t]{2}{*}{$\mathbf{A}$} & $\begin{array}{c}\text { Coliformes } \\
\text { fecais } \\
<1000 \\
\text { NMP/g }\end{array}$ & 1 & 0 & 0 & 0 & 0 & 0 & 0 & 0 & 0 \\
\hline & $\begin{array}{l}\text { Salmonellas } \\
\quad<3 / 4 \mathrm{~g}\end{array}$ & 0 & 0 & 0 & 0 & 0 & 0 & 0 & 0 & 0 \\
\hline B & $\begin{array}{l}\text { Coliformes } \\
\text { fecais } \\
<2.000 .000 \\
\text { NMP/g }\end{array}$ & 1 & 0 & 0 & 0 & 0 & 0 & 0 & 0 & 0 \\
\hline
\end{tabular}

Foi efetuada uma amostragem para confirmação dos resultados, com 10 amostras, sendo as amostras 1, 3 e 4 na pista CAL, amostras 2, 5, 6 e 7 na ABS e 3, 8, 9 e 10 na pista $A B S+C A L$. Os resultados encontram-se na Tabela 30: 
Tabela 30: Confirmação dos resultados da qualidade microbiológica das amostras de torta précondicionada com cal e cloreto férrico, antes e depois da mistura com aditivos adicionais (base seca)

\begin{tabular}{|c|c|c|c|c|c|c|c|c|c|c|}
\hline \multirow{2}{*}{$\begin{array}{c}\text { Parametros } \\
\text { de } \\
\text { Controle }\end{array}$} & \multicolumn{10}{|c|}{ Amostras } \\
\hline & 1 & 2 & 3 & 4 & 5 & 6 & 7 & 8 & 9 & 10 \\
\hline Colif. fecais & 0 & 0 & 0 & 0 & 0 & 0 & 0 & 0 & 0 & 0 \\
\hline $\begin{array}{c}\text { Salmonelas } \\
s p\end{array}$ & $\begin{array}{c}\text { Ausên } \\
\text { cia }\end{array}$ & $\begin{array}{l}\text { Ausên } \\
\text { cia }\end{array}$ & $\begin{array}{c}\text { Ausèn } \\
\text { cia }\end{array}$ & - & - & - & $\overline{-}$ & - & $=$ & - \\
\hline
\end{tabular}

9. No ensaio de resistência à compressão simples os resultados mais favoráveis foram obtidos com 17,5\% de cal adicional na amostra, quando, após 5 dias, foi obtido o mínimo requerido de $0,4 \mathrm{kgf} / \mathrm{cm}^{2}$. Usando-se $5 \%$ de cal adicional este resultado foi conseguido após duas semanas. Com $8 \%$ de cal e $4 \%$ de Absorsol houve acréscimo da resistência à compressão simples com o tempo, mas o mínimo requerido não foi alcançado. Com uso exclusivo de apenas $7 \%$ de Absorsol não houve resistência à compressão.

10. No ensaio de determinação do Índice Suporte Califórnia, a pista construida com $17,5 \%$ de cal alcançou o índice mínimo de resistência pré-estabelecido $(0,4$ $\mathrm{kgf} / \mathrm{cm}^{2}$ ) em cinco dias. Usando-se $5 \%$ de cal ou $8 \%$ de cal e $4 \%$ de Absorsol, este indicador foi atingido após cerca de 17 dias. Dentro do periodo de observação das pistas de 0 a 40 dias, para a mistura com $5 \%$ de cal os resultados do ISC foram continuamente crescentes com o tempo. Para a pista construida com $8 \%$ de cal e $4 \%$ de Absorsol, a tendência de crescimento do ISC apareceu após 23 dias. $\mathrm{O}$ uso exclusivo do Absorsol não apresentou resultados favoráveis.

11. A taxa de decréscimo da umidade nas pistas foi mais rápida na que recebeu exclusivamente $7 \%$ de Absorsol, tendo sido observado um acréscimo de cinco pontos na concentração de sólidos após 10 dias. Foram necessários 15 dias para que as outras pistas obtivessem cinco pontos de acréscimo em suas respectivas concentrações de sólidos iniciais. Em 35 dias houve um aumento de 7 pontos na 
concentração de sólidos da pista construida usando somente Absorsol e de 5 pontos na construída com $17,5 \%$ de cal como aditivo.

12. Foi observado desprendimento de amônia como conseqüência da mistura das tortas com 5\% e com $17,5 \%$ de cal, tanto na preparação da mistura (Figura 18) como no seu lançamento (Figuras 20 e 22), com os riscos associados tendo sido apontados na tese. Foi também notado que o desprendimento do gás aumentava com o aumento da dosagem de cal adicionado na mistura para a pista. Houve mau cheiro e atração de vetores (insetos). Não foi observada a ocorrência do gás associado ao uso do Absorsol, seja durante a mistura seja quando do lançamento e compactação das tortas na pista. 


\section{DISCUSSÃO}

Na RMSP, o condicionamento das tortas de filtro prensa com cal continua sendo feito na ETES ABC e Suzano para lodos digeridos anaerobiamente e na ETE Parque Novo Mundo como forma de estabilizar e diminuir a umidade do lodo flotado.

Considerando que todas as tortas têm como destinos prioritários programados ou a agricultura ou o aterro exclusivo, os resultados dos experimentos desta tese, realizados na ETE Barueri, são aplicáveis para as três depuradoras acima e neste particular é importante chamar a atenção para:

- todas amostras colhidas diretamente das tortas précondicionadas com cal foram classe II;

- quando três amostras foram misturadas com $17,5 \%$ de cal a concentração de fenóis ficou acima do limite para a classe II e o lodo foi classificado como residuo perigoso, classe I;

- o mesmo ocorreu com uma outra amostra de duas outras que receberam $8 \%$ de cal e $4 \%$ de Absorsol, existindo a possibilidade de que a razão pela qual uma delas não tenha concentrado fenóis na massa bruta tenha sido os $4 \%$ de Absorsol.

- ficou evidenciado que a cal virgem contribuiu para aumentar a concentração de fenóis. 
Pode ser concluído que tortas de lodo condicionadas com cal algumas vezes passarão de resíduo não inerte, não perigoso (classe II) para residuo perigoso, classe I. Para cumprir a legislação vigente deverão ser acondicionadas em tambores para disposição confinada especial, incineradas ou dispostas em aterros industriais classe 1.

$\mathrm{O}$ aterro exclusivo da Sabesp foi projetado obedecendo ao prescrito para um aterro classe I (vide página 3), de tal modo que tais lodos poderiam ser dispostos no aterro exclusivo. Por outro lado, como indicado no item 4.2.2.1 (página 66), a presença de fenóis não é considerada impeditiva para o uso agrícola nem pela P 4.230 da Cetesb (1999), nem pela 40 CFR Part 503 (rev. 1997), donde parece imprescindivel a responsabilidade de dispor $o$ resíduo de forma ambientalmente adequada, independentemente das normas vigentes, sem prejuizo de se propor a atualização da prática lá recomendada.

Conclui-se que o aterro exclusivo ou não, para estar apto a receber o lodo condicionado com cal virgem deverá ser aterro classe $\mathrm{I}$.

Pelos valores obtidos, considerando-se os parâmetros de controle de patógenos, a torta do filtro-prensa da ETE - Barueri poderia ser classificada como classe A. Para que possa ser comercializada livremente, ensacada ou a granel, para aplicação em jardins e gramados sem restrições de acesso ao público nas áreas aplicadas, é necessário que o lodo seja resultante de um processo PFRP (Process to Further Reduce Pathogens) ou processo de redução avançada de patógenos, o que não ocorre na ETE - Barueri. Deve ser ressaltado que a norma $\mathrm{P} 4230$ da Cetesb, que ainda não havia sido promulgada à época da presente pesquisa, impede a venda mesmo que o lodo obtenha a classificação $\mathrm{A}$ por medida de precaução (Cetesb, 12/99).

Como lodo classe $\mathrm{B}$ pode ser aplicado a granel em áreas que tem acesso público controlado, como é o caso dos reflorestamentos e de cultivos particulares, especialmente de grãos. 
Foi observado que a torta que não recebeu cal adicional, apenas Absorsol, ganhou em trabalhabilidade e permeabilidade, características desejáveis para o uso agrícola, como discorrido no item 1.5. Esta mesma torta não poderia ser disposta no aterro exclusivo, pois não ofereceu capacidade mensurável de suporte ao tráfego pelos indicadores usados.

O teor de cal virgem necessário ao condicionamento do lodo dos filtros-prensa da ETE Barueri, quando précondicionandos com cal, pode ser inferior ao sugerido nos estudos do plano diretor $(17,5 \%)$, como indicado pela curva de variação do indice quando a dosagem foi de $5 \%$ apenas.

O Índice de Suporte Califórnia é freqüentemente usado para avaliar a capacidade de suporte do solo com sua umidade natural, e a decisão entre escavar e substituir o solo para construção da rodovia ou usá-lo como sub-base é norteada pelos seguintes valores indicativos (Alphageos, 1999):

- Para o ISC $<2 \%$ o material é considerado sem suporte, devendo ser removido.

- $4 \%<\mathrm{ISC}<6 \%$ o material pode ser usado em corpos de aterros, sem contato direto com tráfego.

- ISC $>12 \%$ material bom para sub bases, não sendo necessária sua remoção

Pode ser mencionado que a norma "Especificações Gerais para Obras Rodoviárias do DNER - Volume - I / IV - DNER - ES 282/97", no seu parágrafo 5.1.4, afirma que "na execução do corpo dos aterros não será permitido o uso de solos de baixa capacidade de suporte (ISC < $2 \%$ ) e expansão maior do que $4 \%$."

No caso dos aterros de lodo não será necessária a obtenção de um indice tão bom quando o especificado para base de rodovias, acreditando-se que alguma acomodação 
sob o tráfego de veiculos seja vantajosa por estar aumentando a compactação do aterro. Os critérios acima servirão, contudo, como indicadores e como uma referência para a comparação relativa de efeitos dos aditivos minerais.

A Figura 28 mostra que o lodo misturado com $17,5 \%$ ou com $5 \%$ de cal ultrapassa o ISC de $2 \%$. Nas proporções de $8 \%$ de cal e $4 \%$ de Absorsol tende a ultrapassar o mínimo admissível pelo DNER após 24 dias.

Como demonstrado pelos resultados dos ensaios de resistência à compressão simples e Índice Suporte Califórnia, o polímero na preparação da torta torna inviável a execução de um aterro exclusivo com os lodos.

Deve-se destacar que, quando da execução de ensaios em pista experimental com tortas condicionada com cal e cloreto férrico, foram encontrados valores mais favoráveis na pista em comparação com valores obtidos em laboratório com o mesmo material.

\section{CONCLUSÕES}

Tendo em vista a boa qualidade constatada para o lodo da ETE Barueri, a tendência mais recomendável seria usá-lo como condicionador de solos para a agricultura.

A supressão da cal virgem na torta trouxe como vantagem a diminuição do risco de se encontrar fenóis nos exames da massa bruta por ocasião das classificações periódicas do lodo. Sendo classificado como resíduo não inerte, provavelmente será enquadrado na classe " $B$ ", ou mesmo na " $A$ ", se alguns dos processos para esta classificação forem implantados na ETE. Não basta que os resultados laboratoriais revelem indicadores que obedeçam ao estipulado nas normas (da Usepa ou da Cetesb), é necessário, também, que o lodo tenha passado por processos aprovados como produtores de lodo " $B$ " ou que 
sejam considerados, pelo órgão ambiental, como aptos para produzir lodo "A" (Santos, 2001).

Como também visto, a mistura do Absorsol com as tortas que forem encaminhadas para a agricultura tenderia a valorizar a aparência e a funcionalidade do produto biossólido. Seria recomendável construir pistas experimentais no primeiro dos terrenos escolhidos para os três aterros exclusivos ao longo da Sabesp, tendo-se em vista que continua ativa a produção de lodo preparado com cal em três das cinco ETES da área metropolitana. A julgar pelos resultados obtidos, o uso do Absorsol evitaria a liberação de fenóis, manteria o lodo na classe II, evitaria a produção de amônia, melhoraria a qualidade do chorume e as condições ambientais no aterro.

Quanto à ETE Barueri especificamente, uma outra possibilidade é trazida pela maior quantidade de água carreada pelas tortas e pelas caracteristicas reológicas da massa de lodo após a introdução dos polímeros no pré-condicionamento. As tortas julgadas inadequadas ou excedentes da demanda agrícola, por motivo sazonal ou outros, não podendo ser dispostas no aterro exclusivo pelas razões debatidas, poderiam ser incineradas ou secas termicamente, duas formas adequadas para o encaminhamento ao aterro pois, (1) contomam a deficiente capacidade de suporte das tortas preparadas com polímero e, (2) diminuem substancialmente o volume de lodos a aterrar, prolongando a vida útil do sítio escolhido.

Pode ainda ser observado que a combustão de tortas de lodo com concentrações de sólidos de 30 a 50\% é autógena (WEF,1991), situação abrangente tanto da concentração de sólidos atual (36\%), quanto da que existia no passado (41\%), com a observação que, atualmente, a necessidade de incinerar tornou-se maior pela impossibilidade de dispor nos aterros exclusivos a torta como hoje é produzida. 


\section{REFERÊNCIAS BIBLIOGRÁFICAS}

Alphageos. Condicionamento químico complementar experimental para a disposição da torta ETE Barueri - AGR/3082- 01. São Paulo. SP. Alphageos Geologia, Geotecnia e Comércio Ltda. Sabesp. 1998

Alphageos. Relatório Final sobre ensaios de resistência à compressão simples e Índice de Suporte Califórnia em amostra de torta de filtro prensa cujo lodo foi condicionado com polímeros - ETE Barueri - AGR/3370. São Paulo. SP. Alphageos Geologia, Geotecnia e Comércio Ltda. Sabesp 1999

AMC - Agrícola Metals Corporation. Some frequently asked questions about zeolite. Available at: (http://www.agricolametals.com/faq.html) 2002[20.01.03]

Banks CJ; Heaven. Landfilling. In: S. Spinosa, L e Vesilind, PA. Sludge into Biosolids: Processing, Disposal. IWA Publishing. 2001. p75 - 98.

Bioservices GSA. BioTer - AbsorSol - Biofil - La solución ecológica definitiva Available in: http://www.asesorarteam.com/bioservices.html. 2002 [ 10.01.03]

Bisogenin JLM. Secagem de lodo de ETA em leito convencional. In: $\mathbf{2 0}^{\circ}$ Congresso Brasileiro de Engenharia Sanitária e Ambiental, Anais em CD-ROM. Rio de Janeiro, RJ: ABES, 1.999

CETESB. Aplicação de lodos de sistemas de tratamento biológico em áreas agrícolas - Critérios para projeto e operação (Manual Técnico). Norma Técnica P 4.230.1999. 
Clogrennane. Soil. Stabilisation - Emerging Technology in Ireland. 2002.

Clogrennane Lime Ltd. Available from: www.dpsnet.com/lime/stabilisation.html [3.01.2003].

Déak B. Landfilling. In: Sludge Treatment and Disposal - Management Approaches and Experiences. European Environment Agency - IWSA, Copenhagen. 1997. p 36-40.

Dixon JB. Roles of Clays in soils. Applied Clay Science, 5.1991.pp489 - 503.

DNER-ES 282/97. Aterros Available at: http: // www. solocap. com. Br /normas /terrapln /es28297.htm

[19.01.03]

Farrell JB. Old biosolids in a dried-up lagoon. Biosolids \& Solids Discussion Fórum. Range of topics: Wastewater Residuals, 503 Regulations, Conditioning, Thickening, Dewatering, Stabilization, Beneficial Use, Public Education. Water Environment

Federation. July ,11, 2000. Available at:

http://www.wef.org/Forums/Index.cfm?CFApp=6\&Message_ID =6039 [4.01.2003]

Fuzaro JA. Aterros Sanitários em Valas. Cetesb. 1998

Globo, Manual do Engenheiro. Manual do Engenheiro Globo - Enciclopédia das Ciências e Artes dps Engenheiro e do Arquiteto. 4v. 2 ed. Editora Globo. 1957.

Haberl R; Salzer C. Dewatering of sewage sludge with vacuum assisted sludge dewatering beds. Wat. Sci. Tech., 26, 9-11, 1992. 2273-2276.

Kenji MM. Utilização de polimeros para condicionamento de lodo de ETE para desidratação em filtro prensa de placas. In: $\mathbf{2 0}^{\circ}$ Congresso Brasileiro de Engenharia Sanitária e Ambiental. I-109. 1998. p.556-566. 
Kirk-Othmer. Adsortion. Encyclopedia of Chemical TEchnology. 4th ed. V1. John Wiley \& Sons. 1991

Lima MRP; Muller, PSG; Gonçalves, RF. Taxas de aplicação de lodo de lagoas anaeróbias de estabilização para desidratação em leitos de secagem. In: $20^{\circ}$ Congresso Brasileiro de Engenharia Sanitária e Ambiental. I-090. 1998. p.412 - 421.

Lue-Hing, C; Zenz. DR; Kuchenrither, R. Utilization of municipal sewage sludge as daily and final cover for municipal solid waste landfills. In: Municipal sewage sludge management: processing, utilization and disposal. Water Quality Management Libray, v.4; Lancaster, Pennsylvania; 1992. p. 346-353.

Miki MK; Andrigueti EJ; Sobrinho PA. Tratamento da fase sólida em estações de tratamento de esgotos. In: Tsutiya, MT et al., cditores. Biossólidos na Agricultura. SabespUSP-Esalq-Unesp.São Paulo : SP; 2001. p 41 - 87.

NB 570. Projeto de estações de tratamento de esgoto sanitário. ABNT - Associação Brasileira de Normas Técnicas. 1990.

NBR 10004. Resíduos Sólidos - Classificação. ABNT - Associação Brasileira de Normas Técnicas. 1987.

NBR 12770. Solo coesivo - Determinação da resistência à compressão não confinada. ABNT - Associação Brasileira de Normas Técnicas.1992.

NB 9895 / MB2545. Solo - Índice Suporte Califórnia. ABNT - Associação Brasileira de Normas Técnicas. 1987. 
Nogueira R; Santos HF. Cobertura Final de Células de Lodo com Solo - Um Ensaio Realizado. III Simpósio sobre barragens de rejeitos e disposição de resíduos REGEO'95, Ouro Preto, MG, 1995

Nogueira R; Santos HF. Disposição de Lodos de ETE's em Aterros Exclusivos. III Simpósio sobre barragens de rejeitos e disposição de resíduos - REGEO'95, Ouro Preto, MG, 1995

Pattrol. Ensaio Califórnia. Pattrol Pavimentos, Traçados e Obras, Ltda. Available at: http://www.pattrol.com.br/equipamentos/califo.html [19.01.03].2002

Peres LEP. Nutrição mineral das plantas. Escola Superior de Agricultura "Luiz de Queiroz". Available at:

(http://orion.cpa.unicamp.br/sbfv/arquivos/aulas/grad02/07 nutricao mineral/Nutricao Mineral.pdf][20.01.03]

Promotora Nacional SA. Natural zeolite for wastewater applications. Available at: http://www.water-technology.net/contractors/wastewater/promotora/index.Html\# promotora3. 2002[20.01.03]

PMC-ES 015/99. Terraplenagem - Compactação de aterro. Especificação de serviço. Available at: http://www.ippuc.org.br/bid/caderno_encargos/PMC_ES\%20015_99.PDF [19.01.2003] pp. $1-4.1999$

Sabesp. EIA do aterro exclusivo dos lodos - Tomo 1/5 - Informações gerais e caracterização do empreendimento - Células de Disposição e Detalhes e 4.10. Descrição Geral do Aterro. Sabesp. 1995. FL 4.13, pp 110-123, pp $136-139$. 
Sabesp. Desenvolvimento das alternativas de disposição e/ou aproveitamento dos lodos das estações de tratamento de esgotos de Barueri, Suzano, ABC, Parque Novo Mundo e São Miguel. Relatório Parcial 6. Sabesp; 1996.

Sabesp. Plano Diretor de Uso / Disposição dos Lodos das ETE'S da RMSP - R. 24.593 Arq. Tec. 4/1998. Relatório Sintese 1v.- Consórcio Etep - Estática - JNS. 1998

Sabesp. Gestão dos Lodos da Barueri. Relatório de Suporte à Decisão - R 3 2/2002. 1v.-Consórcio Etep - Estática - JNS. 2002

Sabesp (b). Síntese de Informações Operacionais dos Sistemas de Tratamento de Esgotos da RMSP. Julho/01 - Junho/02. AE - Unidade de Negócios de Tratamento de Esgotos. AEEE - Divisão de Engenharia de Desenvolvimento Operacional.2.002.

Santos HF. Processos de Desidratação Térmica para Lodos de Estações de Tratamento de Esgotos. Monografia. Pós-Graduação em Saneamento Ambiental. Universidade Mackenzie, 1993.

Santos HF. Uso agrícola do biossólido das estações de tratamento de esgotos sanitários (ETEs). Subsídios para elaboração de uma norma brasileira. Dissertação de Mestrado, Universidade Mackenzie, São Paulo, 1996. 74 p.

Santos HF; Guimarães, MO, Giusti, PEA. Uso do biossólido de ETEs em reflorestamentos. In: Aesabesp, Saneas, vol 10. Anais do VIII Encontro Técnico da Associação de Engenheiros da Sabesp. 1997

Santos HF, 2001. Normatização para uso agrícola dos biossólidos no exterior e no Brasil. In: Lodo de esgotos: tratamento e disposição final. v6. Princípios do Tratamento biológico de águas residuárias. Ed. Andreoli AV; Sperling M; Femandes. UFMGSanepar.. Belo Horizonte 2001, p.425-464 
Sieger RB; Padgham H; Clancy KM. Total wastewater solids management for the city of Alexandria, Egypt. In: The Management of Water and Wastewater Solids for the $21^{\text {st }}$ Century. WEF. Washington, DC. - 19-22/6.1994.p8 - 47 a 8 - 55 .

Total Química. Amônia anidra $\left(\mathrm{NH}_{3}\right)$. FISPQ. Total Química Indústria e Comércio Ltda. Revisão 12/2001. Available in: www.totalquimica.com.br/FISPQ-Amonia.doc $[4.01 .03] .2001 . \mathrm{pl}-8$.

Tsutiya MT. Características de biossólidos gerados em estações de tratamento de csgotos. In: Tsutiya, MT et al., editores. Biossólidos na Agricultura. Sabesp-USP-Esalq-Unesp.São Paulo : SP; 2001. p 93-96

Usepa. U.S. Federal Register 40 CFR Part 503. Standards for the use or disposal of sewage sludge. Protection of Environment, Chapter I.- Sewage Sludge. e - CFR . Eletronic Code of Federal Regulations. (This data current as January 1, 2003) Available at: http://www.access.gpo.gov/nara/cfr/cfrhtml_00/Title_40/40cfr503_00.html [4.01.2003]

Usepa. US Federal Register 40 CFR Part 258. Criteria for Municipal Solid Waste Landfills. Available at: http://www.epa.gov/epaoswer/non-hw/tribal/pdftxt/40cfr258.pdf. $1996 . p 378-415[4.01 .2003]$

Usepa. Biosolids Generation, Use and Disposal in the United States. EPA 530-R-99-009. 1999 p22

Usepa. Guide to field storage of biosolids. EPA/832-B-00-007. 2000 p134

Vasconcellos HOB, Santos HF, Andrigueti EJ, Shimp GF, Sandino J. Sao Paulo, Brazil: a case study on residuals management master planning for large metropolitan areas. In: 68th Annual Conference of the Water Environment Federation. 1995,outubro, 21-25. Miami - FL.WEFTEC.Session 16. 
WEF/ASCE. Design of Municipal Wastewater Treatment Plants. WEF Manual of Practice No.8. ASCE Manual and Report on Engineering Practice No.76. v II;1991. Thermal Destruction; p. 1430. 
ANEXO A

Caracterização química do sílico-aluminato de cálcio e magnésio, Absorsol 
FOLHA DE DADOS PARA SEGURANÇA NO TRABALHO

\author{
ABSORSOL INDUSTRIAL \\ FORNECEDOR - SOL MINERALES DO BRASIL LIMITADA \\ PRODUTO (NOME COMERCIAL) - ABSORSOL DRY \\ CARACTERIZAÇÃO QUTMICA - Sílico-aluminato de Cálcio e Magnésio \\ DADOS FÍSICOS E DE SEGURANÇA
}

- Estado sólido, cor branca, sem cheiro.Grãos: $95 \%$ entre 0,15 e 3,0 mm

- Mudança de estado - Sólido a líquido: $1.385^{\circ} \mathrm{C} \pm 10^{\circ} \mathrm{C}$

- Temperatura de amolecimento $-1.370^{\circ} \mathrm{C} \pm 10^{\circ} \mathrm{C}$

- Densidade real $-2,3 \mathrm{~g} / \mathrm{cm}^{3}$

- Densidade aparente $-0,45$ a $0,50 \mathrm{~g} / \mathrm{cm}^{3}$

- Solubilidade em água - Insolúvel

- Solubilidade em ácido acético - Insolúvel

- $\mathrm{pH}-7,5$

- Ponto de combustão - Não tem. Material ignifugo.

- Temperatura de combustão - Não tem. Material ignífugo.

- Limite de explosão - Não tem.

- Decomposição térmica - Estável até $1.100^{\circ} \mathrm{C}$

- Condutibilidade térmica - Nula

- Absorção de água - $90 \% \pm 10 \%$ em peso

- Absorção de óleos $-65 \% \pm 10 \%$ em peso

- Resistência mecânica a umidade - $92 \%$ da resistência a seco 
- Superficie especifica $-400 \mathrm{~m}^{2} / \mathrm{g}$

- Capacidade de troca catiônica $-48,7 \pm 5 \mathrm{meq} / 100 \mathrm{~g}$

- Produtos perigosos de decomposição - Nenhum

- Reações químicas perigosas - Nenhuma

- Regulamentação de periculosidade - Nenhuma

\section{COMPOSIÇÃo QUÍMICA MÉdIA}

- $\mathrm{SiO}_{2}-68 \%$

- $\mathrm{Al}_{2} \mathrm{O}_{3}-12 \%$

- $\mathrm{Fe}_{2} \mathrm{O}_{3}-4 \%$

- $\mathrm{CaO}-2 \%$

- PPC - 10 (perda por calor)

- $\mathrm{MgO}-1,5 \%$

- $\mathrm{Na}_{2} \mathrm{O}-1 \%$

- $\mathrm{K}_{2} \mathrm{O}-0,5 \%$

- $\mathrm{TiO}_{2}-0,5 \%$

MEDIDAS DE PROTEÇÃO, ARMAZENAMENTO E MANUSEIO

- Medidas técnicas de proteção - não são requeridas medidas especiais pois o produto não é prejudicial à saúde.

- Proteção - Máscara antipó para operações de carga e descarga de caminhões. Transporte normal de minerais em sacos de $20 \mathrm{~kg}$.

- Higiene no trabalho - Lavar com água

- Proteção contra incêndios e explosões - Nenhuma

- Residuos - Podem ser lançados em aterros. O produto é um excelente condicionador de solos para vegetação. 
- Medidas recomendadas em caso de acidentes - Nenhuma. Produto ignífugo. Se ingerido em quantidades moderadas não é prejudicial à saúde. 
ANEXO B

Ilustração esquemática das amostras de laboratório para as situações das tortas preparadas com: 1 - cal e cloreto férrico e 2 - polímero 
Ilustração esquemática das amostras de laboratório para as situações das tortas preparadas com: 1 - cal e cloreto férrico e 2 - polímero.

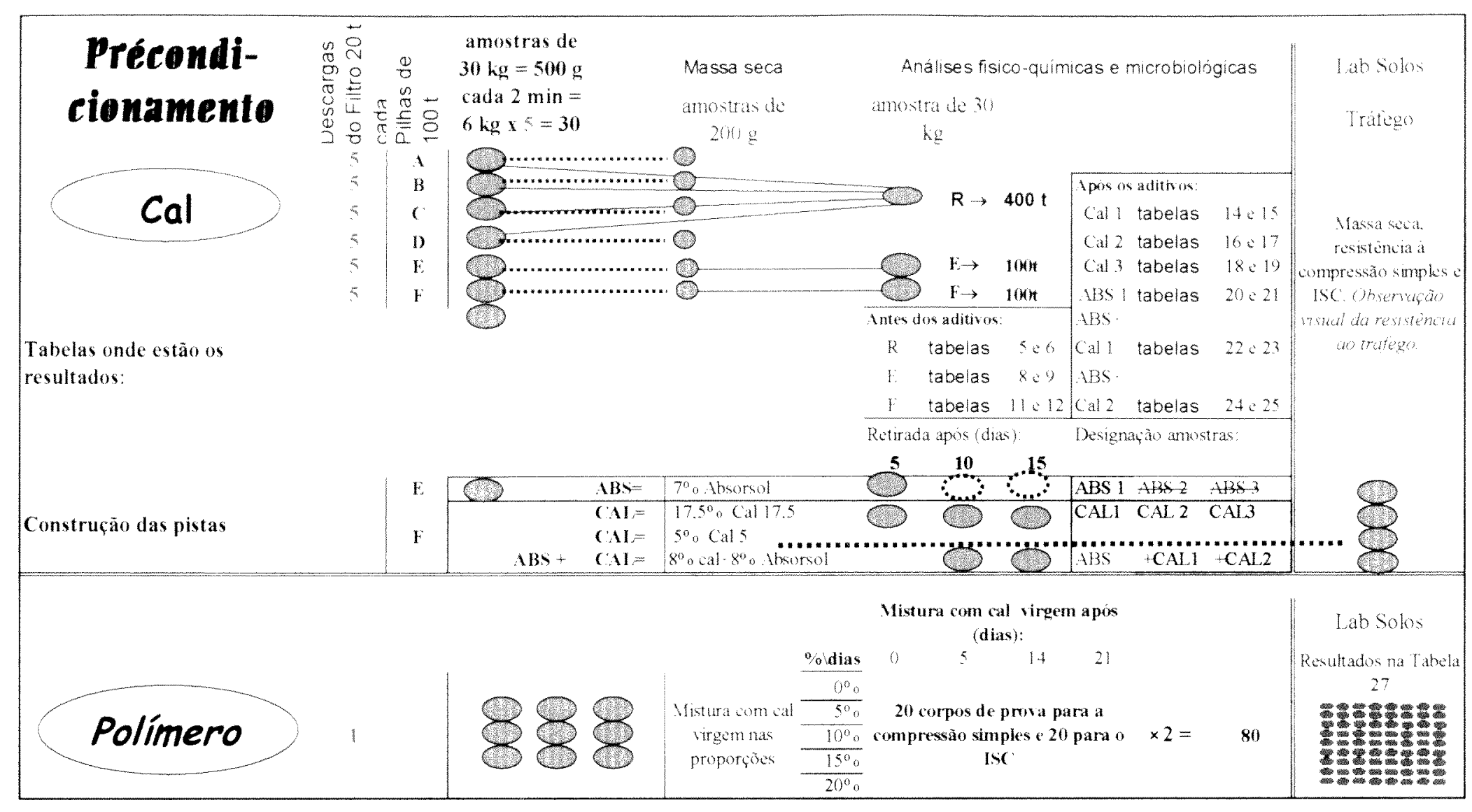

